NATALIE CAROLINA DE CASTRO

\title{
A GLICERONEOGÊNESE E O METABOLISMO DO LACTATO SE MODIFICAM COM O JEJUM A APRESENTAM DIFERENTES CARACTERISTICAS CONFORME A LOCALIZAÇÃO DO DEPÓSITO ADIPOSO
}

Tese Apresentada ao Instituto de Ciências Biomédicas da Universidade de São Paulo para a obtenção do título de Doutor em Ciências 
UNIVERSIDADE DE SÃO PAULO

INSTITUTO DE CIÊNCIAS BIOMÉDICAS

NATALIE CAROLINA DE CASTRO

\section{A GLICERONEOGÊNESE E O METABOLISMO DO LACTATO SE MODIFICAM COM O JEJUM A APRESENTAM DIFERENTES CARACTERÍSTICAS CONFORME A LOCALIZAÇÃO DO DEPÓSITO ADIPOSO}

Tese Apresentada ao Instituto de Ciências

Biomédicas da

Universidade de São Paulo para a obtenção do título de Doutor em Ciências

Área de concentração: Fisiologia Endócrina

Orientador: Prof. Fábio Bessa Lima

Versão Corrigida. A Versão orginal eletrônica encontra-se disponível tanto na Biblioteca do ICB quanto na Biblioteca Digital de Teses e Dissertações da USP (BDTD) 
DADOS DE CATALOGAÇÃO NA PUBLICAÇÃO (CIP)

Serviço de Biblioteca e Informação Biomédica do Instituto de Ciências Biomédicas da Universidade de São Paulo

(c) reprodução total

Castro, Natalie Carolina de.

A gliceroneogenese e o metabolismo do lactato se modificam com o jejum e apresentam diferentes características de acordo com a localização do depósito adiposo / Natalie Carolina de Castro. -- São Paulo, 2016.

Orientador: Prof. Dr. Fabio Bessa Lima.

Tese (Doutorado) - Universidade de São Paulo. Instituto de Ciências Biomédicas. Departamento de Fisiologia e Biofísica. Área de concentração: Fisiologia Humana. Linha de pesquisa: Fisiologia do tecido adiposo.

Versão do título para o inglês: The glyceroneogenesis and the metabolism of lactate modify with fasting and presents different characteristics according to the location of fat depot.

1. Jejum 2. Adipócito 3. Tecido adiposo 4. Lipogênese 5. Gliceroneogênese 6. Lactato I. Lima, Prof. Dr. Fabio Bessa II. Universidade de São Paulo. Instituto de Ciências Biomédicas. Programa de Pós-Graduação em Fisiologia III. Título. 


\section{UNIVERSIDADE DE SÃO PAULO \\ INSTITUTO DE CIÊNCIAS BIOMÉDICAS}

Candidato(a): $\quad$ Natalie Carolina de Castro.

Título da Tese: $\quad$ A gliceroneogenese e o metabolismo do lactato se modificam com o jejum e apresentam diferentes características de acordo com a localização do depósito adiposo.

Orientador(a): $\quad$ Prof. Dr. Fabio Bessa Lima.

A Comissão Julgadora dos trabalhos de Defesa da Tese de Doutorado, em sessão pública realizada a ./................, considerou
( ) Aprovado(a)
( ) Reprovado(a)

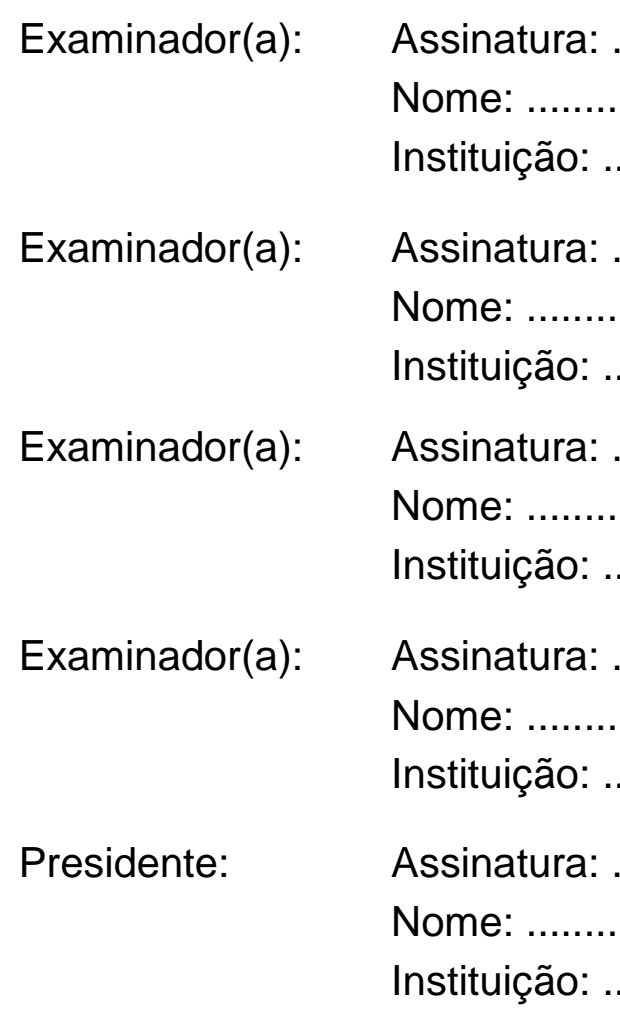




\section{Certificado}

Certificamos que o protocolo registrado sob n 093 nas fls. 131 do livro 02 para uso de animais em experimentação, sob a responsabilidade do Prof(a) Dr(a)) Fabio Bessa Lima , Coordenador (a) da Linha de pesquisa "Efeito do jejum e da realimentação sobre o metabolismo lipogênico de diferentes depósitos adiposo brancos em ratos wistar" do qual participam o(s) aluno(s) Natalie Carolina de Castro, Amanda Barón Camapna, Rennan de Oliveira Caminhotto, está de acordo com os Princípios Éticos de Experimentação Animal adotado pela Sociedade Brasileira de Ciência de Animais de Laboratório (SBCAL) e foi aprovado pela COMISSÃO DE ÉTICA NO USO DE ANIMAIS (CEUA) em 24.08.2012, com validade de 4 anos.

São Paulo, 28 de agosto de 2012.
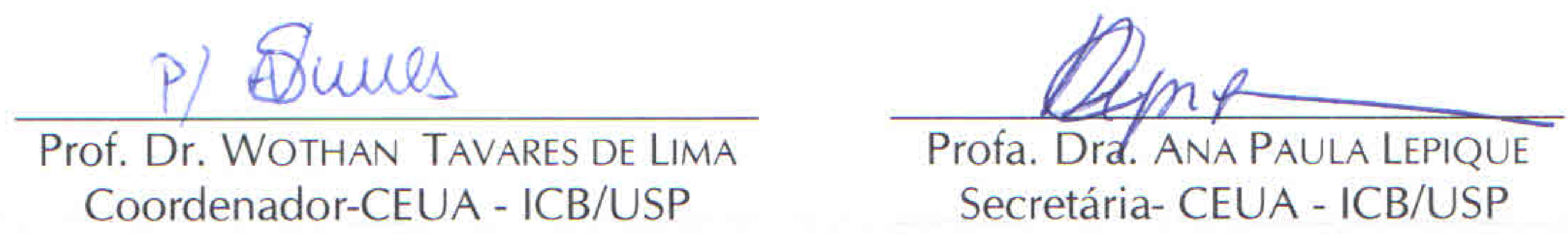


\section{AGRADECIMENTOS}

Gratidão ao meu mestre querido Fabio Bessa Lima, que me abriu as portas do seu laboratório, confiou em minha capacidade de trabalho e me permitiu aprender com ele e com toda sua equipe científica. Hoje é mais que um mestre, tornou-se um grande amigo, a quem tenho um enorme respeito, admiração e carinho.

Agradeço muito ao meu marido Eduardo Antonelli, que esteve ao meu lado em todos os momentos desta jornada, acompanhou e compartilhou comigo as alegrias, as dificuldades e com muita paciência e carinho, abdicou muitos de seus dias de descanso para que conclusão deste trabalho fosse possível.

Agradeço aos meus amigos do Laboratório (Sandra Andreotti Sertie, Rogerio Sertie, Amanda Baron Campaña, André A. Proença, Rennan Caminhoto, Gabi Boltes, André Luiz Vianna e Ayumi Komino) que me apoiaram e compartilharam seus conhecimentos em todos estes anos de convivência.

Aos competentes secretários da pós-graduação do ICB, Jose Maria e Paloma, meus sinceros agradecimentos pela disposição, prontidão e carinho em todos os momentos que solicitei.

Agradeço aos porteiros e seguranças do ICB, que pernoitam na portaria e garantem nossa segurança nas madrugadas de experimentos, e aos funcionários do Biotério do ICB que cuidam dos animais e garantem a limpeza do ambiente e saúde dos animais que trabalhamos. 
Grata Senhor! Por me permitir encontrar este caminho! 
"Rendarse como en me rendi. Mergulhe no que você não conhece como en mergulhei. Não se preocupe em entender, a viver ultrapassa qualquer entendimento" 


\section{RESUMO}

Castro NC. A gliceroneogênese e o metabolismo do lactato se modificam com o jejum e apresentam diferentes características de acordo com a localização do depósito adiposo. [tese (Doutorado em Fisiologia Humana)]. São Paulo: Instituto de Ciências Biomédicas da Universidade de São Paulo; 2016

Com a redução de nutrientes durante o jejum, ocorre intensa mobilização de ácidos graxos (AG) do adipócito. A intensidade com este processo é executada parece ser altamente controlada, pois evita que haja excesso de AG circulante que pode resultar em prejuízos metabólicos e propiciar o aparecimento de condições patológicas. Assim, para evitar lipólise excessiva, o excedente de AG pode e é reesterificado ao glicerol-fosfato para $\circ$ que a Gliceroneogênese torna-se indispensável. Nesta via metabólica, especialmente em condições de jejum, o lactato se constitui em um substrato fisiológico importante. Este trabalho procurou averiguar esta hipótese e sua importância no jejum e no estado alimentado. Metodologia. Ratos machos Wistar foram divididos em dois grupos, Alimentado (Al) e Jejum (J) e adipócitos dos coxins subcutâneo (SC) e visceral retroperitoneal (RP) foram submetidos a testes biológicos e estudos moleculares. Nos testes de Incorporação de $\left[{ }^{14} \mathrm{C}\right]$-Acido Lático em Glicerol e de captação de $\left[{ }^{14} \mathrm{C}\right]$-Ácido Lático, adipócitos de animais alimentados $(\mathrm{J})$ apresentaram menor capacidade funcional (Al > J; $\left.{ }^{*} \mathrm{p}<0.05[\mathrm{~N}=8]\right)$. Nestes testes, a presença de glicose (1 ou $4 \mathrm{mM}$ ) no meio foi fundamental para a exacerbação das respostas celulares e a insulina (10 nM) intensificou ainda mais as respostas biológicas em ambos os tecidos. Contudo, a resposta biológica verificada não se acompanhou de alteração na expressão do transportador de monocarboxilatos 1 (MCT1) e da enzima fosfoenol piruvato carboxiquinase (PEPCK) no grupo $\mathrm{Al}$ em relação ao J. Concluímos que o jejum promove redução da gliceroneogênese e da captação de ácido lático no tecido adiposo sem, contudo alterar a expressão da PEPCK ou de MCT1. Tanto glicose como insulina são potencializadores da Gliceroneogênese no tecido adiposo.

Palavras-Chave: Jejum. Adipócito. Tecido Adiposo. Lipogênese. Gliceroneogênese. Lactato 


\begin{abstract}
Castro NC. The glyeroneogenesis and the metabolism of lactate modify with fasting and presentes different characteristics according to the location of fato depot. [Ph.D. (Human Phisiology)]. São Paulo: Instituto de Ciências Biomédicas da Universidade de São Paulo; 2016.
\end{abstract}

As nutrient support declines during fasting, intensive fatty acid (FA) mobilization takes place in the adipocyte. How intense this process is performed seems to be a well controlled phenomenon that avoids the excessive presence of fatty acids in blood which could lead to severe metabolic damage and allow the development of pathologic conditions. Therefore, to keep away from an excessive lipolysis, the surplus of fatty acids released can and is re-esterified to glycerolphosphate to which glyceroneogenesis becomes indispensable. In this metabolic pathway, especially during fasting, lactate becomes an important substrate. This study aimed to assess this hypothesis and to check its relevance in fed and fasted states. Methodology. Male adult Wistar rats were divided into two groups: Fed (Al) and Fasted (J) and adipocytes from fat pad subcutaneous (SC) and visceral retroperitoneal (RP) were subjected to biological assays and molecular studies. In the tests of $\left[{ }^{14} \mathrm{C}\right]$-Latic Acid Incorporation into Glycerol and of lactic-acid uptake, adipocytes from fasted animals showed reduced functional capacity $\left(A l>J ;{ }^{*} p\right.$ <0.05; [N = 8]). In these tests, the presence of glucose (1 or $4 \mathrm{mM}$ ) was fundamental to exacerbate cellular responses and insulin (10 nM) intensified them in both tissues. However, these biological responses were not accompanied by similar alterations in the protein expressions of monocarboxylate transporter 1 (MCT1) and of the enzyme phosphoenol pyruvate carboxykinase (PEPCK). No differences were observed between $\mathrm{Al}$ and $\mathrm{J}$. We concluded that feeding promotes increased glyceroneogenesis and lactic acid uptake although without affecting PEPCK and MCT1 protein expressions. Both glucose and insulin were potentiators of glyceroneogenesis.

Keywords: Fasting. Adipocyte. Adipose Tissue. Lipogenesis. Glyceroneogenesis. Lactate. 


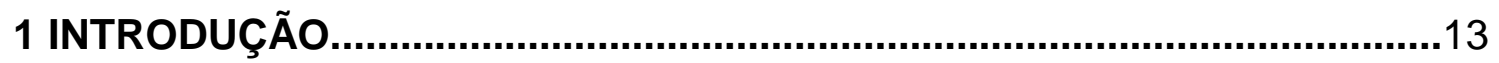

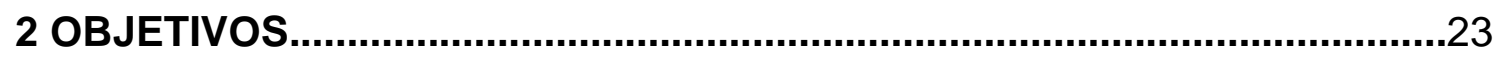

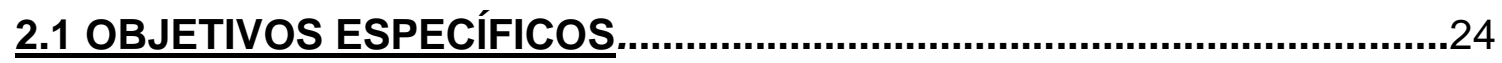

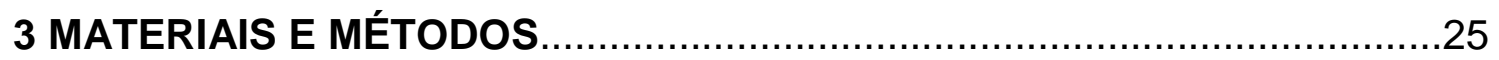

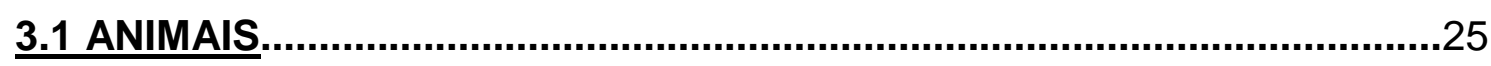

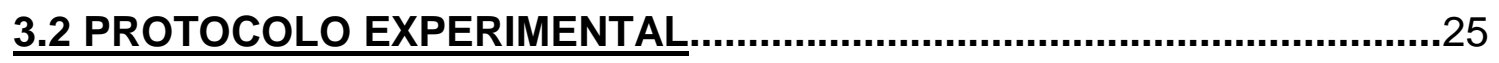

3.3 ISOLAMENTO DOS ADIPÓCITOS E ANÁLISE MORFOMÉTRICA...........26

3.4 TESTE DE INCORPORACÃO DE D-[U- $\left.{ }^{14} \mathrm{C}\right]$-Glicose ou $\left[{ }^{14} \mathrm{C}\right]$-ACIDO

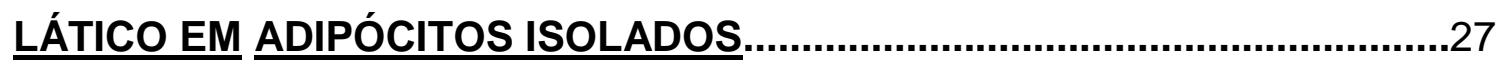

3.5 INCORPORACÃO DE D-[U- $\left.{ }^{14} \mathrm{C}\right]$-GLICOSE E DE ${ }^{14} \mathrm{C}$-ÁCIDO LÁTICO EM

GLICEROL DE TRIGLICÉRIDES EM ADIPÓCITOS ISOLADOS....................28

3.6 CAPTACÃO DE $\left[{ }^{14} \mathrm{C}\right]$-ÁCIDO LÁTICO EM ADIPÓCITOS ISOLADOS......29

3.7 LEPTINA

3.8 INSULINA

3.9 GLICOSE

3.10 LACTATO

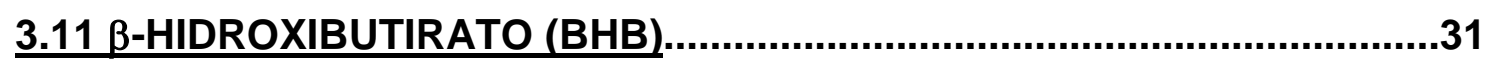

3.12 EXPRESSÃO DE PROTEÍNAS - WESTERN BLOTTING......................32

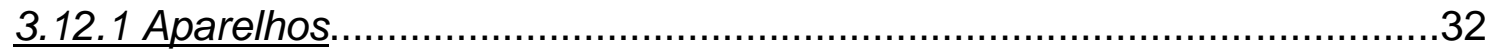

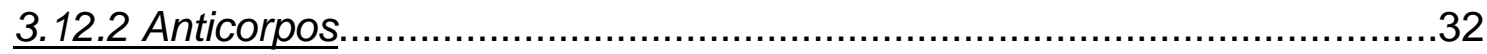

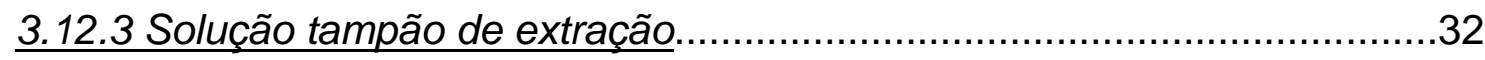

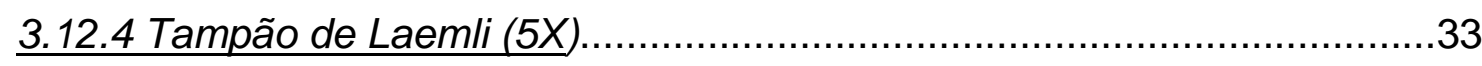

3.12.5 Solução tampão utilizada na eletroforese

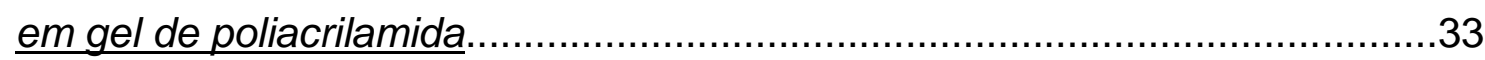

3.12.6 Solução tampão para transferência.....................................................33

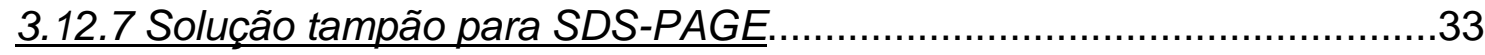

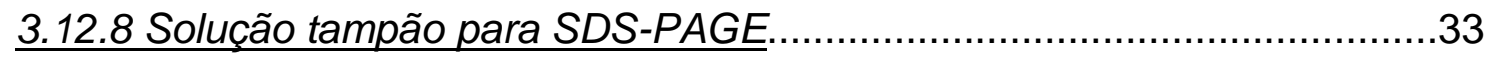

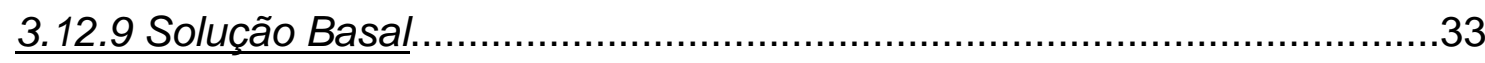

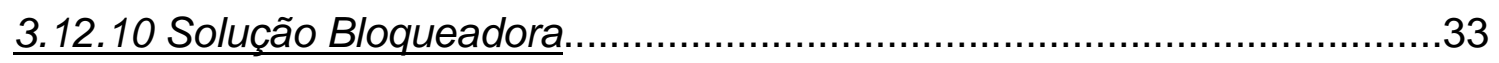

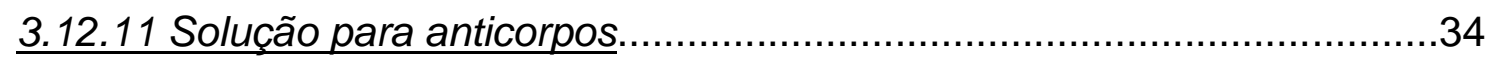

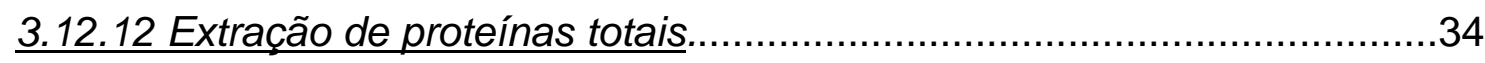

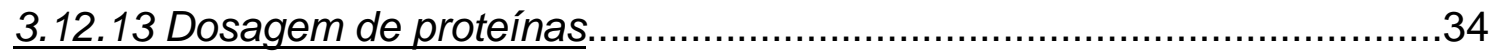

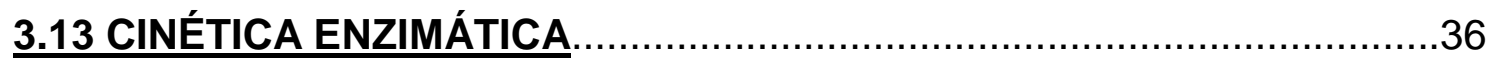




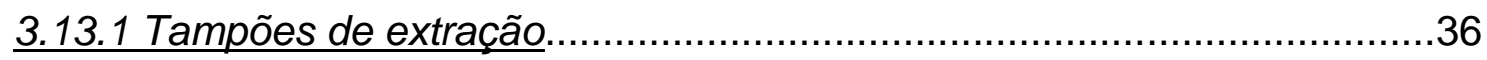

3.13.2 Glicose 6 Fosfato Desidrogenase (G6PDH) ....................................36

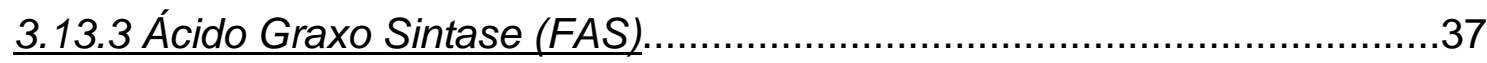

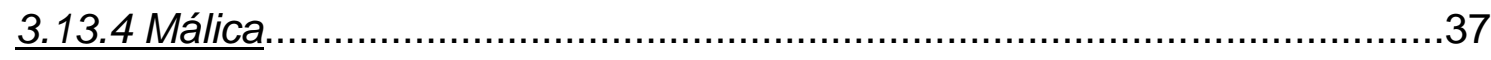

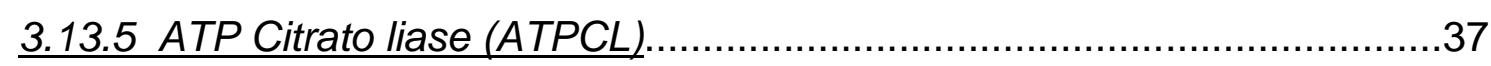

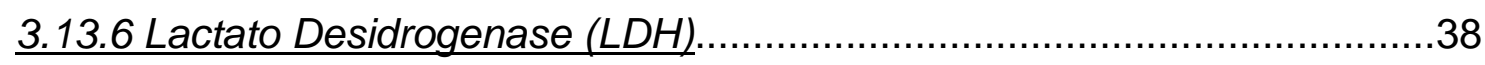

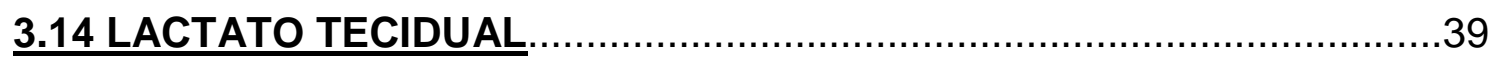

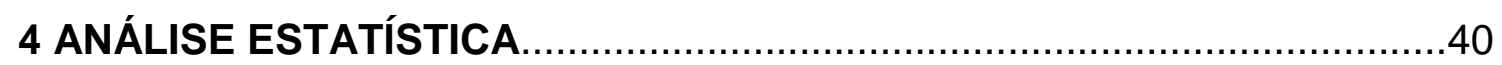

5 RESULTADOS

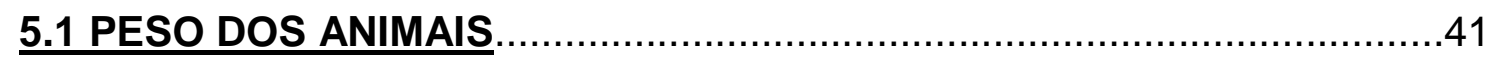

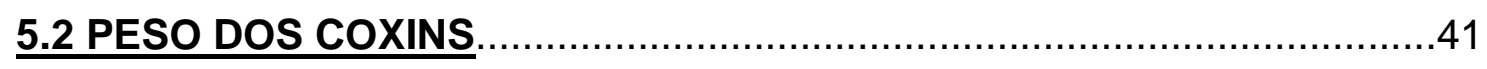

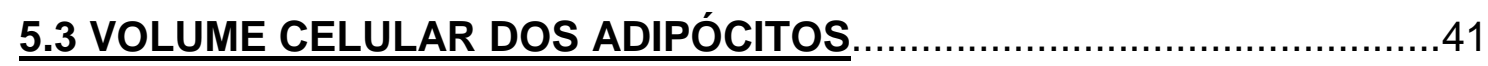

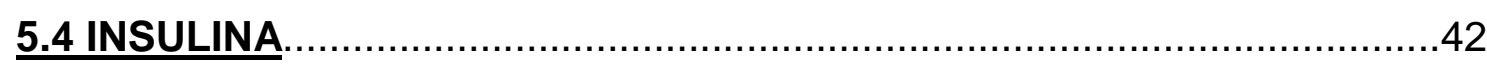

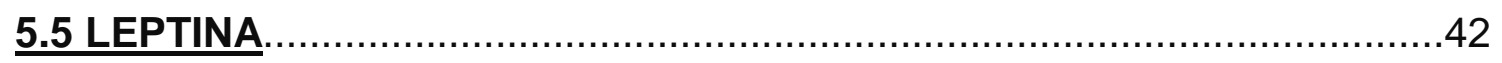

5.6 GLICOSE

5.7 LACTATO

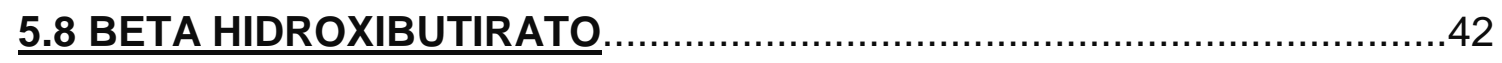

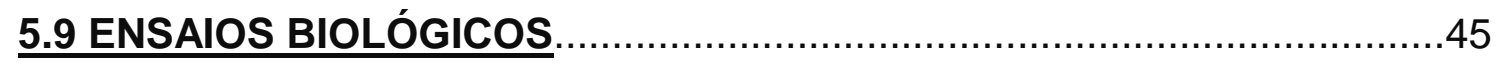

5.9.1 Influência da Glicose no Teste de Incorporação de $\Gamma^{14} \mathrm{Cl}$-Acido

Lático em Adipócitos Isolados de animais Alimentados..................................45

5.9.2 Incorporação de $D$ - $\left[U-{ }^{14} \mathrm{C}\right.$-Glicose e de ${ }^{14} \mathrm{C}$-Ácido

Lático em Lipídios.

5.9.3Incorporação de $D-\left[U-{ }^{14} \mathrm{C}\right]$-Glicose e de ${ }^{14} \mathrm{C}$-Ácido

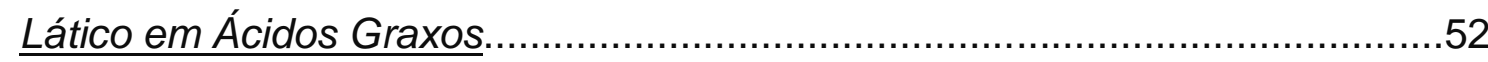

5.9.4 Incorporação de D-[U- $\left.{ }^{14} \mathrm{C}\right]$-Glicose ${ }^{14} \mathrm{C}$-Ácido Lático em Glicerol de

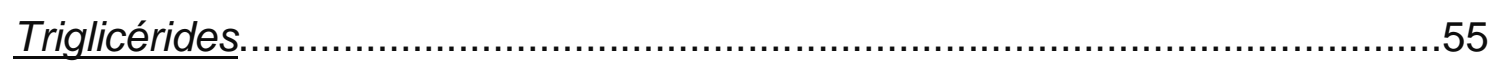

5.9.5 Captação de ${ }^{14} \mathrm{C}$ - Ácido Lático em adipócitos isolados............................58

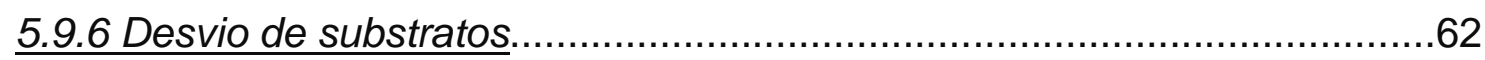

5.10 EXPRESSÃO DE PROTEÍNAS (WESTERN BLOTTING)......................66

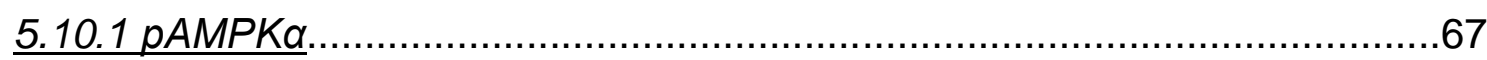

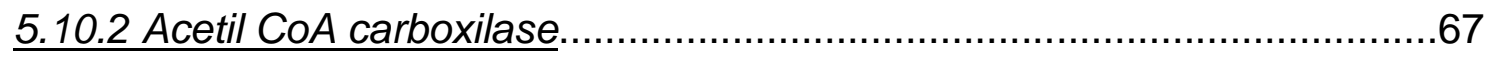

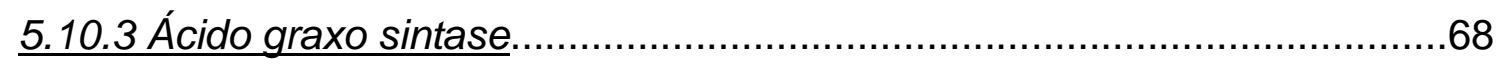

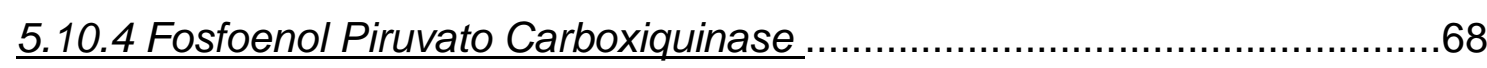

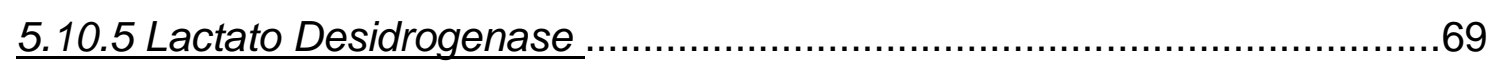

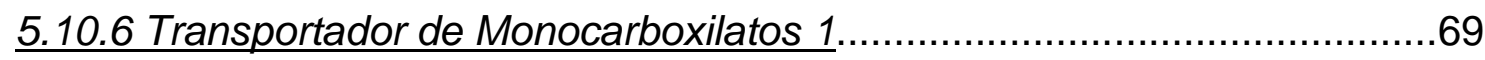

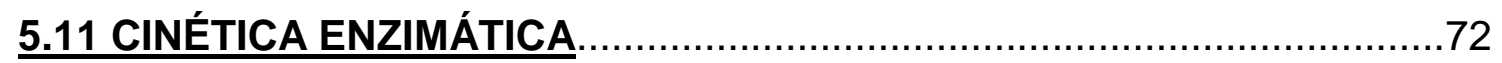


5.11.1 ATP citrato liase

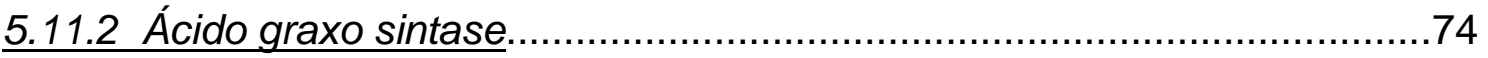

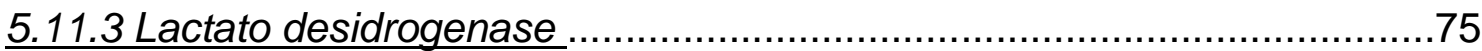

5.11.4 Glicose -6-fosfato-desidrogenase ...................................................... 76

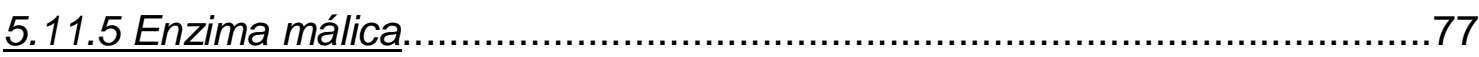

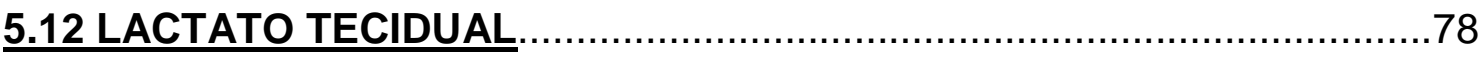

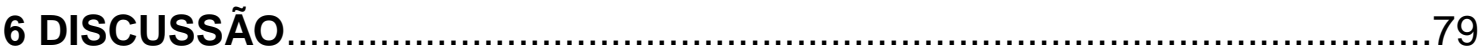

7 CONCLUSÃO

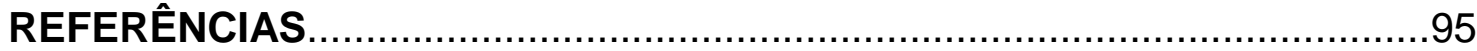




\section{INTRODUÇÃO}

O tecido adiposo (TA) constitui-se no mais amplo depósito de material energético com ampla e difusa distribuição pelo organismo e não possui forma definida. Embora em seu bojo contenha diversos espécimes celulares, o seu elemento parenquimal mais predominante é o adipócito que possui forma aproximadamente esférica, quando completamente isolado, e diâmetro variável (entre 20 e $200 \mu \mathrm{m}$, em humanos). Seu citoplasma tem como característica fundamental a presença de um vacúolo lipídico único que ocupa a porção central da célula rebatendo todas as demais organelas (núcleo, mitocôndrias, retículos endoplasmáticos, etc.) mais a porção aquosa citoplasmática para a periferia. $\mathrm{O}$ vacúolo gorduroso compreende aproximadamente $90 \%$ da massa celular. (Cinti., 2005)

A sua ampla distribuição atinge desde regiões mais superficiais, como a subcutânea, sob a extensão da pele, a regiões mais profundas, conectando-se a vísceras e músculos. O tecido adiposo visceral, localizado dentro da cavidade abdominal, forma inúmeros aglomerados, como o visceral omental, conectado ao estômago e pâncreas; o mesentérico, conectado ao intestino; o perirrenal, ligado aos rins; o periepididimal, ligado ao epidídimo e o retroperitoneal localizado na parede posterior da cavidade abdominal, entre outros depósitos (Bouchard et al., 1993; Cinti., 2012)

O volume dos adipócitos do tecido visceral mostra-se maior comparativamente ao tecido subcutâneo. Na região visceral, a lipólise é mais intensa e mais pronunciada quando sob a ação de agonistas $\beta$-adrenérgicos e glicocorticóides. No tecido hepático, o produto desta intensa atividade lipolítica pode causar nos hepatócitos defeitos como a esteatose não-alcoólica que pode gerar disfunções hepáticas graves como a esteato-hepatite, além de causar dislipidemias, comuns em indivíduos obesos. No entanto, esta variação metabólica entre os tecidos não está bem esclarecida (Dicker et al., 2004). Ainda sobre a relação entre o volume celular e metabolismo do adipócito, a sensibilidade à insulina e a captação de glicose parecem ser inversamente proporcionais ao volume dos adipócitos, estreitando ainda mais a relação entre adiposidade visceral e DM2, sendo o aumento da adiposidade visceral um preditor de alterações do metabolismo da glicose. 
Os diferentes sítios de localização do tecido adiposo no organismo desempenham suas funções de maneiras distintas como também respondem a estímulos externos como dietas, exercícios e drogas de formas diferentes. Entre as diferenças dos depósitos adiposos, destaca-se o tamanho médio dos adipócitos, que pode interferir sobre a sua capacidade metabólica que, não raro, agravam as complicações em consequência à obesidade, ao diabetes mellitus e à hipertensão arterial (Garaulet et al., 2006). O controle do volume celular pode ser secundário à dieta e ao estilo de vida, depende da ação sincronizada de hormônios específicos, ou mesmo de características próprias e fatores locais da região em que estes adipócitos se encontram (Di Girolamo et al.,1998)

Um estudo anterior realizado pelo nosso grupo avaliou o perfil metabólico de adipócitos isolados provenientes dos tecidos SC, PE e RP de ratos Wistar. Várias diferenças foram observadas entre células provenientes de cada região, como diferenças no tamanho médio dos adipócitos, na sua celularidade, nas respostas metabólicas em testes biológicos, na expressão de proteínas e na atividade enzimática. Em relação ao tamanho celular, adipócitos oriundos da gordura retroperitoneal eram, em média, significativamente maiores que os periepididimais e estes maiores que os subcutâneos. O tecido RP mostrou maior capacidade lipogênica e respondeu mais intensamente nos testes de captação e de oxidação de glicose, estimuladas pela insulina. Confrontando-se as respostas celulares com o tamanho médio dos adipócitos, independentemente da região adiposa de origem, observou-se uma correlação positiva, isto é, células maiores apresentavam maior capacidade de lipogênese e de oxidação da glicose. Entretanto, em relação ao teste de captação de glicose, isto não se verificou. Ao contrário, os adipócitos maiores, quando estimulados por insulina, eram menos responsivos, havendo, portanto, uma correlação inversa da resposta biológica com o tamanho celular (Castro., 2010).

Além disso, o conceito de que o excesso de adiposidade está associado a complicações metabólicas e hemodinâmicas que levam freqüentemente ao desenvolvimento de resistência à insulina e de doenças cardiovasculares não é recente.

A adiposidade abdominal, em particular a adiposidade visceral, composta de adipócitos predominantemente mais volumosos, está intimamente ligada ao desenvolvimento de resistência à insulina, hipertensão e dislipidemias. Em situações em que há expressivo acúmulo de tecido adiposo visceral e, juntamente com o 
aumento da produção de adipocinas, ocorre em paralelo, associação deste tecido com o surgimento e agravamento de resistência à insulina, DM2, hipertensão e dislipidemias (Giorgino et al., 2005). Jernas (2006) mostrou que adipócitos do mesmo tecido, isolados e separados em células maiores e menores, apresentaram diferenças entre si na expressão de diversos genes. Como foi o caso de alguns marcadores inflamatórios associados à obesidade e DM2 e o transporte reverso do colesterol. Estas proteínas mostraram expressão mais intensa em células hipertrofiadas que em células menores de um mesmo tecido, comprovando que o volume celular, por si só, pode modular a funcionalidade do adipócito.

Em indivíduos eutróficos, o tecido adiposo branco representa aproximadamente $20 \%$ do peso corporal total e pode ser considerado, no seu conjunto, como um dos maiores órgãos do organismo. Quanto ao consumo de oxigênio, possui capacidade limitada. De acordo com estudos, sua produção de energia parece não ultrapassar $5 \%$ do total do gasto energético do organismo. Por esta razão, foi por muito tempo considerado um tecido dotado de pouca atividade metabólica tendo alguma importância como um tecido protetor contra agressões mecânicas ou com capacidade isolante térmica. No entanto, nas últimas décadas, avanços importantes surgiram revelando que este tecido possui profundo envolvimento no controle metabólico global, principalmente em relação aos carboidratos e lipídios, além de atuar como tecido capaz de armazenar grande quantidade de energia em forma de triacilgliceróis (TAG) (composto estruturalmente formado por três moléculas de ácidos graxos e uma de glicerol, unidas por ligações ésteres) no vacúolo lipídico dos adipócitos. (FonsecaAlaniz et al., 2006)

A distribuição difusa da massa adiposa permite que o TA exerça controle metabólico, mediante sinais endócrinos e parácrinos, influenciando diversos territórios do organismo, como: cérebro, músculo, fígado, pâncreas, e outros (Bouchard et al.,1993). Como um órgão endócrino, o tecido adiposo possui capacidade de sintetizar e secretar hormônios e citocinas (também denominados adipocinas).

A leptina, por exemplo, um hormônio peptídico com peso molecular de aproximadamente $16 \mathrm{kDa}$, sintetizado e secretado principalmente pelo TA, foi descoberto em 1994 e contribuiu de forma significativa para que o TA fosse reconhecido como um órgão endócrino e não mais somente como um tecido cuja função restringia-se a armazenar ou fornecer energia. Seus receptores são encontrados em diversas regiões do cérebro, particularmente no hipotálamo, e em 
regiões extra cerebrais como placenta, gônadas e tecido adiposo principalmente. Por ser sintetizada em adipócitos, a leptina guarda relação positiva com a massa de gordura corporal. Além disso, tem, como reguladores, hormônios que atuam no metabolismo energético, como a insulina e glicocorticoides. $O$ fator de transcrição C/EBP- $\alpha$ (CCAAT/enhancer binding protein $\alpha$ ), regulado pela insulina é fundamental para a total atividade do promotor de leptina, (Czeq et al., 2013). Sendo assim, a insulina parece aumentar o teor de mRNA da leptina, ao passo que a leptina pode reduzir tanto a secreção de insulina pelas ilhotas pancreáticas quanto seu efeito estimulante sobre a captação de glicose em tecidos diversos. No período pósprandial, onde há oferta de nutrientes, ocorre aumento dos níveis de leptina. No sistema nervoso central, mais precisamente no núcleo arqueado do hipotálamo, a leptina parece reduzir a síntese de Neuropeptídeo Y (NPY), conhecido pela sua participação no controle entre fome/saciedade e termogênese. O NPY possui capacidade de estimular o consumo alimentar ao mesmo tempo em que reduz o gasto energético, além de elevar os níveis de insulina e glicocorticoides no plasma (Lawson et al., 2011). Em situações de privação da alimentação, e consequente redução dos níveis de leptina, fatores ligados à estimulação do apetite são novamente ativados (Donato., 2006). Os níveis de leptina estão sendo relacionados não só a massa adiposa mas também quanto ao volume dos adipócitos, além de ser apontada como um sinalizador do estoque de energia (em forma de triacilglicerol) do organismo, e um fator fundamental no controle das reservas lipídicas do adipócito (Fonseca-Alaniz et al, 2006; Reidy et al.,2002).

Do ponto de vista estritamente metabólico, as principais ações que o tecido adiposo executa são a lipólise e a lipogênese, controladas principalmente por vias neuroendócrinas (Vázquez-Vela., 2008). A lipólise, caracterizada pela hidrólise dos TAG da gota lipídica, é intensificada em situações em que há redução da ingestão de alimentar, como no jejum, ou quando há maior gasto energético, como no exercício físico. Nestas condições, os AG são liberados na corrente sanguínea para serem utilizados como energia em diversos tecidos periféricos. Durante o processo lipolítico, também ocorre a re-esterificação de parte dos ácidos graxos hidrolisados antes mesmo de serem liberados na corrente sanguínea, sendo novamente re-incorporados em TAG nos adipócitos, processo conhecido como re-esterificação de ácidos graxos (Jensen et al., 2001; Weber et al., 2012). Esta reciclagem pode depender da viabilidade de glicerol-3-fosfato (G3P). Em contraste, no período pós-prandial a oferta 
de nutrientes e carboidratos privilegia a lipogênese, ou seja, a síntese e armazenamento de TAG na gota lipídica dos adipócitos. O armazenamento de lipídeos e sua incorporação em TAG dependem, entre outros fatores, da captação de ácidos graxos de TAGs, contidos em quilomícrons, provenientes da dieta, cuja hidrólise envolve a enzima lipase de lipoproteínas (LPL), e o transporte dos ácidos graxos livres através da FATP/CD36 para o citoplasma do adipócito (Ali et al., 2011). Neste processo, reações bioquímicas em sequência têm início e resultam na esterificação de ácidos graxos (AG) ao glicerol-3-fosfato, para a reconstituição do TAG e armazenamento na gota lipídica do adipócito (Forest et al., 2003; Frasson et al., 2012). Além desta via, outros fatores moleculares ligados à lipogênese parecem ser regulados principalmente, através da ação da insulina (Czeq et al., 2013)

A insulina é um hormônio anabólico secretado pelas células $\beta$ das ilhotas pancreáticas, principalmente no período pós-prandial, momento em que há oferta carboidratos e aminoácidos, e é essencial para a manutenção da homeostase glicídica do organismo. A sinalização da insulina começa com sua ligação ao seu receptor específico de membrana (IR). O receptor de insulina é uma tirosina quinase que se autofosforila e catalisa a fosforilação de proteínas intracelulares desencadeando uma sequência de reações que resultam tanto na translocação do transportador de glicose (GLUT 4) para a membrana citoplasmática, o que aumenta a captação da glicose, quanto no estímulo para a lipogênese. (Palou et al., 2010; Zanquetta et al., 2006). Outro fator relevante com relação a lipogênese é a capacidade da insulina em estimular a Proteína Transportadora de Ácidos Graxos 1 (FATP1) e Lipase de Lipoproteínas (LPL) (Wu et al., 2006). Estas proteínas têm atividade ligada a captação de AG do meio extracelular para o interior do adipócito. Neste ambiente, estes AG são esterificados para a síntese do TAG e armazenamento na gotícula lipídica da célula (Ali et al., 2011; Wan et al., 2013).

Há evidencias de que a alimentação e a insulina participem da regulação da lipogênese através do aumento da atividade e da expressão gênica de fatores de transcrição, como o Sterol Regulatory Element-Binding Protein 1c (SREBP 1c) e Carbohydrate-Responsive Element-Binding Protein (ChREBP), que estimulam expressão de genes de proteínas envolvidas na síntese de ácidos graxos, como a como a Acetil CoA carboxilase (ACC) e a Ácido graxo sintase (FAS) (Herman et al., 2012; Im et al., 2006; Kim et al., 1996). Através da lipogênese, o TA armazena o excesso de energia e isto leva à hipertrofia do adipócito, ou mesmo à hiperplasia, 
aumentando o número de células no tecido. Assim, esta expansão do adipócito e do TA possibilitam o estoque de grande quantidade de energia além de proteger outros tecidos viscerais de acúmulos ectópicos de gordura e, consequentemente, da sua toxicidade (Eichmann et al., 2012).

Com relação à lipogênese e síntese de AG, o TA depende da atividade de enzimas induzidas pela insulina, como a ACC e a FAS (Kovacs et al., 2006; VázquezVela et al., 2008). A ACC é uma proteína citosólica, que atua no início da via lipogênica e catalisa a reação irreversível de carboxilação de uma molécula de AcetilCoA a Malonil-CoA, sendo este indispensável para a síntese de ácidos graxos. Já a FAS, é responsável por catalisar o último passo da lipogênese, a conversão de AcetilCoA e Malonil-CoA à ácidos graxos saturados, como o ácido palmítico, por exemplo (Ameer et al., 2014).

A via de síntese de $A G$ à partir de substratos não lipídicos (carboidratos e aminoácidos), é chamada de lipogênese de novo (DNL). Estudos bioquímicos postulam que esta via envolve, entre outros fatores, uma cadeia de reações que se inicia pela formação de acetil-CoA; neste passo, a enzima (ATP citrato liase) ACL exerce papel limitante, já que catalisa a reação que reduz Citrato à acetil-CoA. Em seguida, o acetil-CoA formado, serve de substrato para a enzima da ACC, consequentemente, resultando na formação de malonil-CoA e síntese de AG (Kovacs et al., 2006)

Como já foi citado anteriormente, no interior do adipócito, 3 moléculas de AG devem ser esterificadas em uma molécula de glicerol-3-fosfato (glicerol-3-P), para que - TAG seja formado e estocado na gota lipídica. Por isso, a síntese de glicerol-3-P torna-se imprescindível. Neste processo, os carboidratos são considerados a maior fonte de carbonos para sua síntese. Para a geração de G3P, ocorre a conversão de di-hidroxi-acetona fosfato (intermediário da via glicolítica) a glicerol-3-P, reação esta catalisada pela enzima glicerol-3-P desidrogenase. Além desta via, existe a que utiliza a enzima gliceroquinase (Gyk). Esta última, fosforila diretamente o glicerol a glicerol3-P, entretanto, esta enzima parece não possuir atividade significativamente alta no TA (Frasson et al., 2012; Hanson et al., 2003).

Além das vias supracitadas, outra via de síntese conhecida é a Gliceroneogênese. Esta via é caracterizada pela a síntese de novo de glicerol-3-P a partir de precursores diferentes de glicose e glicerol, como piruvato, lactato e alanina e tem sido apontada como uma via de atividade significativa no TA (Nye., 2008). Com 
relação ao substrato lactato utilizado na Gliceroneogênese, isto é possível graças à sua captação pelo adipócito do meio extracelular, o que ocorre através de seus transportadores, denominados transportadores de monocarboxilatos (MCTs). Estes transportadores constituem uma família de 14 subtipos, sendo MCT1, MCT2 e MCT4 descritos no tecido adiposo. O MCT1 parece ser o principal facilitador bidirecional de lactato no TA, enquanto que o MCT4 está ligado à liberação do lactato do interior do adipócito para o meio extracelular (Hadjuch et al., 2000; Halestrap et al., 2012; Heredia et al., 2009). O lactato é formado em diversas células do organismo como produto da glicólise anaeróbia em diversos tecidos (particularmente de hemácias, de células musculares) e no próprio adipócito (Brooks., 2009). De acordo com Romero (2015), a presença da glicose ou frutose em meio de cultura aumenta substancialmente a produção de lactato por adipócitos da linhagem 3T3L1. Outro estudo conduzido por Muñoz (2010) evidenciou que aproximadamente $70 \%$ da glicose captada pelo adipócito é convertida em lactato através da glicólise anaeróbia. $O$ baixo consumo de oxigênio do TA pode explicar o motivo da significativa utilização da glicose nesta via metabólica (van den Borst., 2013). Independente da origem do lactato, a enzima lactato desidrogenase o converte em piruvato, e a sequência de eventos até a síntese de glicerol-3-P envolve a carboxilação do piruvato a oxalacetato, descarboxilação do oxalacetato a fosfoenolpiruvato e finalmente a formação de glicerol-3-P. A gliceroneogênese envolve também a enzima fosfo-enolpiruvato carboxiquinase (PEPCK), que é apontada como a enzima passo-limitante deste processo. Estudos anteriores evidenciaram que a deleção genética desta enzima leva a perda drástica de TA (Hanson et al., 2003; Muñoz et al., 2010; Oslwang et al., 2002). Além disso, diversos estudos apontam o jejum, o exercício físico, dietas restritivas em carboidratos e diabetes, como os principais ativadores da gliceroneogênese (Botion et al., 1998; Brito et al., 1998). Em paralelo, sua atividade parece ser inibida em situações em que há predomínio da ação da insulina, como no período pós-prandial (Wan et al., 2013). Entretanto, este aspecto ainda não está completamente esclarecido e há pontos controversos na literatura.

Um estudo in vivo, conduzido por Nye (2008), quantificou a gliceroneogênese no tecido adiposo de ratos mantidos com dieta controle (standard), ou submetidos ao jejum por $48 \mathrm{~h}$ ou tratados com dieta lipogênica e rica em glicose. A gliceroneogênese foi quantificada pela incorporação de água tritiada $\left({ }^{3} \mathrm{H}_{2} \mathrm{O}\right)$ ou de $\left[\mathrm{U}-{ }^{14} \mathrm{C}\right]$-glicose em lipídeos. Nos tecidos adiposos epididimal e mesentérico dos animais controle, a 
gliceroneogênese contribuiu com cerca de $90 \%$ da síntese de glicerol de triglicerídeos. Nos animais submetidos ao jejum, a gliceroneogênese não foi afetada e a contribuição da glicose como fonte de carbono para o glicerol foi insignificante. Já, nos animais submetidos a dieta lipogênica, rica em carboidratos, a gliceroneogênese mostrou-se quantitativamente mais intensa se comparada ao grupo controle. Entretanto, a medida da atividade da PEPCK realizada neste estudo, mostrou-se maior em animais privados de alimentação (que apresentaram menor atividade gliceroneogênica) quando comparado aos animais submetidos à dieta rica em glicose.

O jejum é uma situação muito comum em animais de diversas espécies e é também praticado por seres humanos por razões diversas - como parte de tratamentos médicos, objetivos estéticos ou práticas religiosas. (Trepanowski, et al., 2010). O jejum de curta duração ocorre habitualmente no intervalo entre as refeições ou em períodos de descanso como o sono noturno. Esse processo de cessação da ingestão de alimentos também ocorre no decurso de moléstias diversas, de causas variadas - infecções, tumores, processos psicopatológicos (por exemplo, anorexia nervosa). Nestas condições, o balanço energético negativo direciona o metabolismo. Em relação ao tecido adiposo, ajustes endócrinos privilegiam a lipólise, com a consequente mobilização de substratos energéticos endógenos, sobre a lipogênese (Heber., 2010; Robin et al., 2008; Ying-Lee et al., 2006). De acordo com Palou (2008), o aumento de níveis circulantes de ácidos graxos não esterificados (NEFA) e o de $\beta$ hidroxibutirato, iniciam-se após quatro e oito horas de jejum respectivamente. Estas alterações indicam que, com o prolongamento do tempo de jejum, a fonte de energia do organismo é crescentemente oriunda da mobilização lipídica do tecido adiposo. (Eichmann et al, 2012; Palou et al., 2010).

A insulina plasmática e a expressão de transportadores de glicose GLUT4 nos adipócitos reduzem-se após 4 e 8 horas de jejum respectivamente, além de ocorrer queda dos níveis plasmáticos de leptina (Sánchez., 2009; Sucajtys-Szulc et al., 2009). Durante o jejum, a expressão de genes de fatores de transcrição, como SREBP1c, Receptor Ativado por Proliferadores de Peroxissomo gama (PPARy), e de enzimas como FAS, ACC e GPAT, importantes na lipogênese, são rapidamente reduzidas (Palou et al., 2008, 2010; Trepanowski et al., 2010). Assim como são conhecidas às diferenças no metabolismo regional dos distintos territórios adiposos, a secreção de adipocinas, ao lado de fatores genéticos, parecem também diferir entre os depósitos adiposos. (Karastergiou ., 2010; Palou et al., 2010; Ying-Lee et al, 2006). 
A intensidade da mobilização lipídica do adipócito durante a lipólise é controlada através da re-esterificação dos AG. Níveis muito elevados de ácidos graxos livres na circulação, provenientes de intensa lipólise, seja devido ao exercício físico ou durante o jejum prolongado, devem ser controlados. Isso por que os AG são transportados em sua maioria pela albumina, que permanece em concentrações limitadas na circulação (Vanz et al., 2006). Além disso, o excesso de AGL na circulação estão associados a certas condições patológicas, como a acidose metabólica, causada por altas concentrações de corpos cetônicos produzidos pelo metabolismo de lipídios, além de resistência à insulina e diabetes tipo 2 (Cadoudal et al., 2007). De acordo com Jensen (2001) aproximadamente 60\% dos AG oriundos da lipólise são novamente esterificados para a síntese de TG. Este processo é possível graças a síntese de G3P no adipócito, seja através gliceroneogênese, pela ação direta da GyK (pouco expressiva no TA) ou a partir da glicólise. Para Forest (2003), a gliceroneogenêse parece possuir papel importante na homeostase lipídica do organismo (Nye.,2008).

A gliceroneogênese vem sendo estudada e caracterizada com base em trabalhos que utilizam quase que exclusivamente o piruvato como substrato, embora - lactato seja o substrato mais fisiológico e provável neste caso devido a grande quantidade desta molécula no organismo, uma vez que este é metabólito de diversas espécies celulares (Cadoudal et al., 2005). Com relação a algumas das diferenças entre ambos os substratos, o $\mathrm{K}_{\mathrm{M}}$ para a entrada do piruvato no adipócito parece estar em torno de $2000 \mu \mathrm{M}$ e o $\mathrm{K}_{\mathrm{M}}$ para a atividade da $\mathrm{LDH}$ utilizando o mesmo substrato em torno de 50-200 $\mu \mathrm{M}$ (Benetti et al., 2000). Em contraste, o transporte de lactato através da membrana celular de adipócitos isolados não parece ser tampouco saturável. (Hajduch et al., 2000). Sabe-se que os níveis sanguíneos de lactato relacionam-se com a atividade glicolítica anaeróbia de diversos tecidos do organismo. As hemácias, por exemplo, utilizam exclusivamente glicose como substrato energético e através da glicólise anaeróbia liberam constantemente lactato na circulação. De maneira similar, a produção de lactato acontece com diversos outros tecidos, além do próprio TA. (Romero et al., 2015)

$\mathrm{O}$ aumento do nível sanguíneo de lactato seria responsável pela queda do $\mathrm{pH}$ e aumento do tamponamento pelo bicarbonato de sódio, cujos produtos finais são água e $\mathrm{CO}_{2}$.As concentrações plasmáticas de lactato são fruto do turnover desta molécula (Ellmerer et al., 1998). Estudos realizados com lactato marcado demonstram 
que o lactato produzido no organismo é rapidamente removido do sangue e sua concentração tende a permanecer estável, o que mostra a importância do controle dos níveis deste substrato (Arraián et al., 2015; Brooks., 2009; Romero et al., 2015). Com relação a este controle da lactacidemia, o tecido adiposo poderia exercer papel tamponador neste processo, já que é capaz de utilizar o lactato como substrato, tanto para geração de ATP, quanto para a síntese de ácidos graxos e glicerol na gliceroneogênese, contribuindo para a redução da carga ácida no plasma.

Como já foi descrito anteriormente, no período pós-prandial, mecanismos envolvidos na glicólise anaeróbia e na lipogênese são ativados. $O$ aumento do aporte de nutrientes poderia contribuir para elevar a produção de lactato em diversos tecidos. O tecido adiposo teria assim a disposição mais um substrato para a geração de glicerol-fosfato necessário para a recomposição dos estoques de TAG. Em condições de jejum prolongado, em que a produção de lactato pode se acelerar, continua a ocorrer gliceroneogênese cujo propósito seria o de re-esterificar o excesso de AGL liberados pela lipólise e, com isto, impedir uma liberação massiva destes lipídeos, uma vez que a capacidade de transporte plasmático destes substratos é limitada. Assim, a gliceroneogênese é um processo importante tanto para o período pósprandial como para o jejum. Contudo, não é clara a real contribuição da gliceroneogênese do tecido adiposo durante situações de plena oferta de nutrientes (estado alimentado, período pós-prandial) e de sua carência (jejum). Tampouco se conhece o grau de participação de diferentes coxins adiposos (representados por uma gordura superficial, a subcutânea, e outra mais profunda, a retroperitoneal) em relação às duas condições alimentares - jejum e estado alimentado. Seria o processo de gliceroneogênese diferencialmente regulado em cada um destes territórios adiposos?

Para responder a estas questões, o presente trabalho teve como objetivo avaliar a Lipogênese a partir de Lactato e Glicose, e a gliceroneogênese a partir de Lactato em animais em situações experimentais opostas, como o jejum por $48 \mathrm{~h}$ e o estado alimentado, em que grau se dá o controle da atividade das vias envolvidas nestes processos no TA e qual a sua intensidade dependendo do território adiposo estudado. 


\section{OBJETIVOS}

Avaliar a capacidade de lipogênese e gliceroneogênese dos tecidos adiposos SC e RP em animais alimentados e compará-las com animais submetidos ao jejum por 48h, através do estudo metabólico, bioquímico e de expressão proteica. 


\subsection{OBJETIVOS ESPECÍFICOS}

Quantificar a lipogênese e a gliceroneogênese nas diferentes condições experimentais, mediante testes biológicos em adipócitos isolados.

Avaliar a capacidade de Captação de Lactato nos diferentes estados alimentares (Alimentado e submetido ao Jejum 48h) e em dois diferentes coxins gordurosos (SC e RP).

Analisar a cinética de enzimas envolvidas na lipogênese como a $A C L, F A S$, G6PDH, Málica e na Gliceroneogênese, a LDH.

Investigar a expressão de proteínas específicas envolvidas na lipogênese, como ACC, FAS, na gliceroneogênese, como LDH, PEPCK e na captação de lactato, como MCT1 através do Western Blotting. 


\section{MATERIAIS E MÉTODOS}

\subsection{ANIMAIS}

Ratos machos Wistar adultos jovens (12 semanas), foram mantidos sob ciclo de iluminação escuro/claro 12/12 h (período claro iniciando às 6:00 A.M.), temperatura de $25 \pm 2{ }^{\circ} \mathrm{C}$, com acesso irrestrito à água e à ração balanceada Nuvital ${ }^{\circledR}$ (Nuvilab), acondicionados em gaiolas de polipropileno ( $46 \times 24 \times 20 \mathrm{~cm}$.), em número de 1 animal/gaiola. Após a chegada ao Biotério de Experimentação do Departamento de Fisiologia e Biofísica, e após uma semana de ambientação, os animais foram avaliados em duas condições experimentais: Alimentado (Al) e Jejum de $48 \mathrm{~h}$ (J)

\subsection{PROTOCOLO EXPERIMENTAL}

Ao completar 12 semanas (após 47 dias de adaptação ao biotério), os animais foram divididos em dois grupos de ratos com peso corporal semelhantes, grupo Alimentado (Al) e Jejum (J). O grupo $\mathrm{J}$ foi submetido ao jejum alimentar por $48 \mathrm{~h}$, sendo a oferta de água ainda irrestrita. Após este período, animais de ambos os grupos foram sacrificados por decapitação às 8:00 A.M. O sangue truncal $( \pm 3 \mathrm{ml})$ foi coletado em tubos com e sem heparina, centrifugados em centrífuga refrigerada (4 ${ }^{\circ} \mathrm{C}$ ), a $2000 \mathrm{rpm}$ por $10 \mathrm{~min}$ e o soro e o plasma respectivos foram armazenados em freezer a $-20{ }^{\circ} \mathrm{C}$. Em seguida, os coxins gordurosos - retroperitoneal (RP) e subcutâneo (SC) foram retirados para isolamento dos adipócitos, e submetidos, "ex vivo", a testes biológicos. Essas células foram testadas, para avaliação da sua resposta metabólica à lipogênese a partir da glicose ou ácido lático em condições basais ou maximamente estimuladas pela insulina. 


\subsection{ISOLAMENTO DE ADIPÓCITOS E ANÁLISE MORFOMÉTRICA}

Os adipócitos foram isolados mediante a técnica de digestão do tecido pela colagenase, descrita por Rodbell (1964), com algumas modificações para adaptar o método às condições laboratoriais e realização do estudo. Em resumo, os coxins gordurosos retroperitoneal e subcutâneo foram retirados, picados em finos fragmentos e incubados em tampão digestivo (DMEM/HEPES $20 \mathrm{mM} / \mathrm{BSA}$ 4\%, colagenase II SIGMA-ALDRICH, Inc, USA ${ }^{\circledR}-1,0 \mathrm{mg} / \mathrm{ml}, \mathrm{pH}=7,40$ ) por $60 \mathrm{~min}$ a $37^{\circ} \mathrm{C}$ em banhomaria com agitação orbital (150 rpm). Em seguida, as amostras foram filtradas em peneira plástica com malha fina (que retém restos teciduais e vasos não digeridos) e lavada por três vezes com $25 \mathrm{ml}$ de tampão EARLE/HEPES $20 \mathrm{mM} / \mathrm{BSA} 1 \%$, piruvato de sódio $1 \mathrm{mM}$, glicose $1 \mathrm{mM}, \mathrm{pH} 7,4$ e mantido a $37{ }^{\circ} \mathrm{C}$ (tampão EHB). A concentração celular final foi ajustada para 20\% (lipócrito de 20\%, m:v).

Para a determinação dos diâmetros celulares, pequenas amostras de adipócitos dos tecidos SC e RP foram transferidas para solução de formaldeído $3 \%$, montadas em lâminas de microscópio e visualizadas em microscópio Zeiss (Carl Zeiss Micro Imaging GmbH Gattingen), 100x de aumento e o campo foi fotografado com câmera Moticam $10001.3 \mathrm{M}$ Pixels usando programa Motic Image para a medição do diâmetro celular médio (resultante da medida de 100 células). A partir deste valor, assumindo-se que o adipócito isolado é esférico, foi calculado o volume e a área de superfície celular média e o número de adipócitos. 


\subsection{TESTE DE INCORPORACÃO DE D-[U- $\left.{ }^{14} \mathrm{C}\right]$-GLICOSE OU $\left[{ }^{14} \mathrm{C}\right]$-ACIDO LÁTICO EM LIPÍDEOS TOTAIS EM ADIPÓCITOS ISOLADOS}

Adipócitos (lipócrito final de 3\%), em tampão Krebs/Ringer/Fosfato/BSA 1\%; glicose ( $1 \mathrm{mM}$ ) ou Ácido Lático $(1 \mathrm{mM}), \mathrm{pH}=7,4$ a $37^{\circ} \mathrm{C}$, saturado de carbogênio $5 \%$, foram pipetados em tubos de ensaio de polipropileno $17 \times 100$ contendo D-[U- $\left.{ }^{14} \mathrm{C}\right]-$ glicose ou $\left[{ }^{14} \mathrm{C}\right]$-Ácido Lático (1 mM, $1850 \mathrm{~Bq} /$ tubo), com ou sem insulina (10 nM). O volume da reação foi de $0,5 \mathrm{~mL}$. Estes tubos foram vedados com tampas de borracha, enriquecidos com uma atmosfera com $\mathrm{O}_{2}(95 \%) / \mathrm{CO}_{2}(5 \%)$ e incubados por $120 \mathrm{~min}$ em banho-maria a $37^{\circ} \mathrm{C}$. Em seguida, foi realizada a extração dos lipídeos mediante a adição de 2,5 $\mathrm{mL}$ de reativo de DOLE (isopropanol: $n$-heptano: $\mathrm{H}_{2} \mathrm{SO}_{4} 8 \mathrm{~N}$, 4:1:0.25, v:v:v) ao meio de incubação (Lima, 1994; Rodbell, 1964). Os resultados foram expressos em nmol. $\left[10^{6} \text { céls. } h\right]^{-1}$. 


\subsection{INCORPORACÃO DE D-[U- $\left.-{ }^{14} \mathrm{C}\right]-G L I C O S E$ E DE ${ }^{14} \mathrm{C}$-ÁCIDO LÁTICO EM ÁCIDO GRAXO DE TRIGLICÉRIDES EM ADIPÓCITOS ISOLADOS}

Da mistura composta por TAG previamente obtida no Teste de Incorporação de $\mathrm{D}$-[U- $\left.{ }^{14} \mathrm{C}\right]$-Glicose ou de ${ }^{14} \mathrm{C}$-Ácido Lático em Lipídeos, foram retirados $500 \mu \mathrm{L}$, seguidos por secagem completa utilizando-se gás $\mathrm{N}_{2}$. Após este processo, adicionouse $1 \mathrm{~mL}$ de etanol (95\%) e $250 \mu \mathrm{L}$ de $\mathrm{KOH}(40 \%)$, os tubos de ensaio foram frouxamente tampados e colocados em banho-maria à $60^{\circ} \mathrm{C}$ por 1 hora. Em seguida 0 material foi resfriado à temperatura ambiente por aproximadamente 10 min e logo após adicionou-se $2 \mathrm{~mL}$ de $\mathrm{HCL} 3 \mathrm{~N}$ e $2 \mathrm{~mL}$ de n-heptano. Esta mistura foi agitada em vórtex e deixada em repouso por 10 minutos. Uma amostra de $500 \mu \mathrm{L}$ da fase superior desta mistura foi retirada e transferida para um vial contendo $3 \mathrm{~mL}$ de líquido de cintilação que foi finalmente levado ao contador beta por $5 \mathrm{~min}$. 


\subsection{CAPTACÃO DE $\left[{ }^{14} \mathrm{C}\right]$-ÁCIDO LÁTICO EM ADIPÓCITOS ISOLADOS}

Alíquotas de $25 \mu \mathrm{L}$ de suspensão celular (lipócrito 10\%) foram pipetadas em tampão Krebs/Ringer/Fosfato/BSA 1\%, glicose (4mM) e Ácido Lático (2mM) em tubos eppendorf de $2.5 \mathrm{~mL}$ de capacidade. Em seguida, foram adicionados $5 \mu \mathrm{L} \mathrm{de}{ }^{14} \mathrm{C}$ Ácido Lático (0.05 $\mu$ Ci/tubo) e incubados por 10 minutos banho-maria $37{ }^{\circ} \mathrm{C}$. Passados 10 minutos exatos, o transporte foi interrompido com a adição de $250 \mu \mathrm{l}$ de phloretin 0.3 mM (GTB e DMSO 0,05\%). Para avaliação da captação, foi adicionado $500 \mu \mathrm{L}$ de óleo de silicone (densidade=0,963 $\mathrm{g} / \mathrm{ml}$ ) que foram centrifugados por 10 segundos em microcentrífuga (Eppendorff 5415 D). A centrifugação teve como objetivo separar a mistura em três fases: uma superior, contendo células compactadas (agregado celular), uma intermediária correspondente ao óleo e a mais inferior constituída pelo tampão aquoso. Feito isso, foi recolhido o agregado celular e transferido para tubo específico contendo $2.5 \mathrm{~mL}$ de líquido de Cintilação (Universal, ICN) e a radiação emitida aferida em contador beta (Packard, Tricarb 2100 TR). Para a determinação da incorporação inespecífica, foram adicionados, primeiramente a suspensão celular $(25 \mu \mathrm{L})$ em um tubo de ensaio e em seguida, o phloretin (inibidor do transporte de lactato), antes de se acrescentar ${ }^{14} \mathrm{C}$-Ácido Lático. Os resultados foram expressos em pmol. $\left(\mathrm{cm}^{2} .10 \mathrm{~min}\right)^{-1}$ de superfície celular. Metodologia adaptada de Hajduch et al (2000). 


\subsection{LEPTINA}

A leptina foi dosada por kit de radioimunoensaio utilizando-se anticorpo espécie-específico. O kit utilizado foi o RL-83K (Linco Research, St Charles, MO) e todo o procedimento foi realizado segundo as especificações do fabricante.

\subsection{INSULINA}

A dosagem plasmática de insulina no soro foi realizada através de radioimunoensaio, utilizando-se o kit RI-13K (Linco Research Inc., St. Charles, MO), específico para insulina de rato. $O$ procedimento foi desenvolvido segundo as especificações do fabricante.

\subsection{GLICOSE}

A metodologia enzimática é baseada em uma reação em que a glicose oxidase catalisa a reação da glicose a ácido glucônico $+\mathrm{H}_{2} \mathrm{O}_{2}$. O peróxido de hidrogênio formado reage com 4-aminoantipirina e fenol, formando uma antipirilquinonimina vermelha cuja intensidade de cor é proporcional à concentração de glicose da amostra. Kit Glicose Liquiform Lab Test ${ }^{\circledR}$

Para o ensaio, foi pipetado $3 \mu \mathrm{l}$ da amostra (soro coletado no momento da eutanásia dos animais e armazenado em freezer $-80{ }^{\circ} \mathrm{C}$ até o momento de sua utilização), branco ou padrão e $300 \mu \mathrm{l}$ do reagente em placa de Elisa. A placa permaneceu à $37{ }^{\circ} \mathrm{C}$ durante $10 \mathrm{~min}$ e em seguida a leitura foi realizada em espectrofotômetro, sendo a absorbância $520 \mathrm{~nm}$. 


\subsection{LACTATO}

Na presença de oxigênio, a lactato oxidase catalisa a oxidação do ácido lático a, promovendo a formação de piruvato e peróxido de hidrogênio. Em seguida, ocorre uma reação de acoplamento entre o peróxido de hidrogênio, 4-aminoantipirina e toos, catalisada pela peroxidase, produzindo uma quinoneimina que tem máximo de absorbância em $550 \mathrm{~nm}$. O kit utilizado foi o Lactato Enzimático Lab Test ${ }^{\circledR}$

Para executar esta reação foram pipetados, em placa de Elisa, $3 \mu$ de amostra (plasma coletado no momento da eutanásia dos animais e armazenado em freezer $80^{\circ} \mathrm{C}$ até o momento de sua utilização), branco ou padrão e $300 \mu \mathrm{l}$ de reagente. A placa foi homogeneizada e em seguida mantida em espectrofotômetro a $37^{\circ} \mathrm{C}$ por 5 minutos, a absorbância foi determinada em $550 \mathrm{~nm}$.

\subsection{1 $\beta$-HIDROXIBUTIRATO (BHB)}

O método para mensurar os níveis de $\beta$-hidroxibutirato (BHB) no soro é baseado na oxidação de D-3-hidroxibutirato $(\mathrm{BHB})$ a acetato, pela enzima BHB desidrogenase. Concomitantemente a esta oxidação, o cofator $\mathrm{NAD}^{+}$é reduzido a NADH. Esta associação de reações é capaz de alterar a absorbância, e pode ser diretamente correlacionada com a concentração de BHB. O Kit utilizado foi o Ranbut D-3- Hidroxibutirato, Manual, RX Monza (Randox ${ }^{\circledR}$ ).

No ensaio, para $300 \mu \mathrm{l}$ de reagente colorimétrico, foram pipetados $75 \mu \mathrm{l}$ de amostra (plasma coletado no momento da eutanásia dos animais e armazenado em freezer $-80^{\circ} \mathrm{C}$ até 0 momento de sua utilização), branco ou padrão em volume equivalente e $300 \mu \mathrm{l}$ de reagente colorimétrico. Foram realizadas 3 leituras em espectro (Power Wave, BIOTEK ${ }^{\circledR}$ ) sendo uma leitura por minuto, $340 \mathrm{~nm}$ a $37^{\circ} \mathrm{C}$. Os resultados de cada determinação representam a média das três leituras. 


\subsection{EXPRESSÃO DE PROTEÍNAS - WESTERN BLOTTING}

\subsubsection{Aparelhos}

Os aparelhos para eletroforese em gel de poliacrilamida e sódio dodecil sulfato (SDS-PAGE) utilizados foram da Bio-Rad (Richmond, CA). A membrana de nitrocelulose $E C L$ e os kits para detecção por quimioluminescência foram fornecidos pela Amersham (UK).

\section{$\underline{3.12 .2 \text { Anticorpos }}$}

$O$ anticorpo anti-MCT1 e anti LDH foram fornecidos pela Santa Cruz ${ }^{\circledR}$, o antiPEPCK, anti-ACC, anti-Bactina, anti-ACL e anti-FAS pela AbCam ${ }^{\circledR}$, Cambrige, USA. O revelador utilizado foi o Bio Image (Systems, Bio América)

\subsubsection{Solução tampão de extração}

Utilizada para extração de proteínas celulares dos tecidos estudados, contém: EDTA $1 \mathrm{mM} \mathrm{pH}$ 8.0, fluoreto de sódio $500 \mathrm{mM}$, glicerol 10\%, 2\% Nonidet P-40, 150 $\mathrm{mM} \mathrm{NaCl}$, Tris-HCL $20 \mathrm{mM} \mathrm{pH} 7.4$, desoxicolato de sódio $0.5 \%, 0.2 \%$ SDS. Além de coquetel completo de Inibidores de fosfatases e proteases (Roche). Durante todo o tempo de extração, a solução foi mantida a $4{ }^{\circ} \mathrm{C}$.

\subsubsection{Tampão de Laemli (5X)}

Usado para estocar o material extraído e sua posterior aplicação no gel de poliacrilamida para eletroforese (SDS-PAGE), contém: azul de bromofenol 0,1\%,

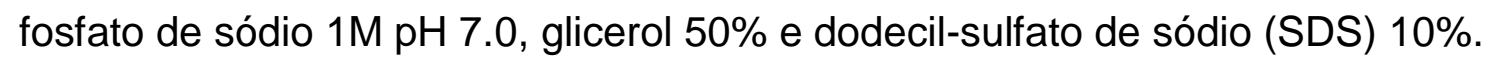




\subsubsection{Solução tampão para eletroforese em (SDS-PAGE)}

Trisma base $200 \mathrm{mM}$, glicina 1,52 M, EDTA 7,18 mM e SDS 0,4\%. Para uso, a solução foi diluída 1:4.

\subsubsection{Solução tampão para transferência}

Empregada para a transferência das proteínas separadas no SDS-PAGE para a membrana de nitrocelulose; contém: trisma base $25 \mathrm{mM}$, glicina $192 \mathrm{mM}$, metanol $20 \%$ e SDS $0,02 \%$ para facilitar a eluição de proteínas de alto peso molecular. Foi estocada a $4 \stackrel{\circ}{\circ}$.

\subsubsection{Gel de resolução (resolving)}

Tampão composto de EDTA $4 \mathrm{mM}$, SDS $2 \%$, trisma base $750 \mathrm{mM}$, com pH ajustado para 8.9 .

\subsubsection{Gel da fase de empilhamento (stacking) das proteínas}

EDTA $4 \mathrm{mM}$, SDS 2\%, trisma base $50 \mathrm{mM}$, com pH ajustado para 6,7 com ácido fosfórico.

\subsubsection{Solução Basal}

Solução para o manuseio da membrana de nitrocelulose após transferência das proteínas contém: cloreto de sódio 150 mM, trisma base 10 mM, tween-20 0,02\%.

\subsubsection{Solução Bloqueadora}

Utilizada para incubar a membrana de nitrocelulose, após a transferência, contém: $5 \%$ de albumina bovina, diluído em solução basal. 


\section{$\underline{3.12 .11 \text { Solução para anticorpos }}$}

Solução contendo anticorpos específicos para identificação das proteínas transferidas para a membrana de nitrocelulose. Contém albumina bovina 0,03\% diluída em solução basal.

\subsubsection{Extração de Proteínas Totais}

Amostras de tecido adiposo SC e RP foram coletadas, transferidas para tubos eppendorfs e homogeneizadas em banho de gelo e em tampão de extração gelado. Para tecidos SC, a proporção entre amostra e tampão foi de 1:3, enquanto que para tecidos RP, foi de 1:1. Os extratos foram centrifugados a $14000 \mathrm{rpm}$ (Eppendorf 5714 R) a $4{ }^{\circ} \mathrm{C}$ por 20 minutos para a remoção do fat cake e coleta do infranadante. Após a centrifugação, os sobrenadantes das amostras tiveram seu conteúdo proteico quantificado utilizando o reagente de Bradford (BioRad, Hercules, Canadá), e foram tratados com tampão de Laemli acrescido de ditiotreitol (DTT) 200 mM, na proporção de 5:1 (V:V).Cerca de $60 \mu \mathrm{g}$ de proteína total foram submetidas a eletroforese em gel de poliacrilamida (SDS-PAGE 10\%) no aparelho para minigel (Bio Rad). Em cada corrida de eletroforese, ao gel foi aplicado o padrão de marcadores de peso molecular pré-corados com valores estabelecidos paralelamente em uma das lanes. 


\section{$\underline{\text { 3.12.13 Dosagem de proteínas }}$}

Para normalizar o conteúdo de proteínas das amostras a serem pipetadas nos géis de eletroforese, realizamos previamente, a dosagem de proteínas por método colorimétrico, utilizando kit Bradford (Bio Rad).

Para a curva de albumina, utilizamos $0.01 \mathrm{~g}$ de albumina diluída em $10 \mathrm{~mL}$ de água. Em seguida, foi aliquotado em 5 eppendorfs contendo $200 \mu \mathrm{L}, 400 \mu \mathrm{L}, 600 \mu \mathrm{L}$, $800 \mu \mathrm{L}$ e $1000 \mu \mathrm{L}$ da solução de albumina além de água MiliQ com volume ajustado para $1 \mathrm{~mL}$.

Em placas de Elisa, foram pipetados $6 \mu \mathrm{L}$ em duplicatas de cada amostra desta curva de albumina, além de $6 \mu \mathrm{L}$ de cada amostras(diluídos de 10x) de tecidos SC e $\mathrm{RP}$ dos animais AL e $\mathrm{J}$ em duplicatas.

Em seguida, foi pipetado $300 \mu \mathrm{L}$ do Reagente Bradford, previamente diluído em água MiliQ na proporção 1:5. A placa foi inserida em Espectrofotômetro a $25^{\circ} \mathrm{C}$, e foi feita a leitura em 10 minutos a 340 nM. 


\subsection{CINÉTICA ENZIMÁTICA}

\subsubsection{Tampões de extração}

Os tecidos adiposos foram completamente homogeneizados em Politron a 0 ${ }^{\circ} \mathrm{C}$, em tampão contendo sacarose $(0.25 \mathrm{M})$, EDTA (1 mM), DTT (1 mM), Leupeptina $(5 \mu \mathrm{M})$ e Aprotinina $(5 \mu \mathrm{M}), \mathrm{pH}$ 7.4. O homogenato foi centrifugado a $7.000 \mathrm{RCF}$ a 0 ${ }^{\circ} \mathrm{C}$ por 5 minutos e os infranadantes livres de gordura foram cuidadosamente retirados e usados para o ensaio destinado a cinética das enzimas G6PDH, FAS, MÁLICA e ACL ou armazenados a $-80^{\circ} \mathrm{C}$.

Para determinar a atividade da enzima LDH, o tampão de extração utilizado continha TRIS HCL (77 mM), EDTA (1 mM), MgCL (2 mM), 2 mercaptoetanol (4 mM), $\mathrm{pH}$ 7,5. O homogenato foi centrifugado a $7.000 \mathrm{RCF}$ a $0{ }^{\circ} \mathrm{C}$ por $5 \mathrm{~min}$ e os infranadantes livres de gordura foram cuidadosamente retirados e usados para 0 ensaio ou armazenados a $-80^{\circ} \mathrm{C}$.

Para os tecidos SC, a proporção entre o peso do tecido e o volume de tampão adicionado foi de 1:3, enquanto que para os tecidos RP foi de 1:1.

Os resultados foram expressos por $\mu \mathrm{mol}$. ( $\mu \mathrm{g}$ de proteínas. min) ${ }^{-1}$, sendo a dosagem proteica realizada pelo método Bradford (Bio-Rad)

\subsubsection{Glicose 6 Fosfato Desidrogenase (G6PDH)}

Em placa de ELISA, foi pipetado primeiramente $15 \mu \mathrm{L}$ da amostra, em seguida $270 \mu \mathrm{L}$ da mistura de ensaio contendo $\operatorname{NADP}^{+}(0.4 \mathrm{mM})$ e TRITON 1\%. Logo após a placa foi colocada em Espectrofotômetro para estabilizar a reação com temperatura a $25^{\circ} \mathrm{C}$, a leitura foi feita em $340 \mathrm{nM}$ por $10 \mathrm{~min}$. Em seguida, iniciou-se a reação, com a adição de $15 \mu \mathrm{L}$ do substrato Glicose- 6- Fosfato (1.2 mM). A leitura teve duração de 10 minutos (Bergmeyer, Bernet., 1974). 


\subsection{3 Ácido Graxo Sintase (FAS)}

Em placa de ELISA, foi pipetado primeiramente $30 \mu \mathrm{L}$ da amostra, em seguida $260 \mu \mathrm{L}$ da mistura de ensaio contendo NADPH $(200 \mu \mathrm{M})$, Acetil CoA $(100 \mu \mathrm{M})$, $\mathrm{KH}_{2} \mathrm{PO}_{4}(100 \mathrm{mM}), \mathrm{pH}$ 6.5. Logo após, a placa foi colocada em Espectrofotômetro para estabilizar a reação com temperatura em torno de $37^{\circ} \mathrm{C}$ e leitura em $340 \mathrm{nM}$ por 10 minutos. A reação foi iniciada com a adição de $10 \mu \mathrm{L}$ do substrato $\mathrm{KH}_{2} \mathrm{PO}_{4}(100$ $\mathrm{mM}$ ) e malonil-CoA $(600 \mu \mathrm{M}), \mathrm{pH}$ 6.5. A leitura foi realizada por $10 \mathrm{~min}$ (Bergmeyer, Bernet., 1974).

\subsubsection{Málica}

Em placa de ELISA, foi pipetado primeiramente $15 \mu \mathrm{L}$ da amostra, em seguida $270 \mu \mathrm{L}$ da mistura de ensaio contendo TRIS $\mathrm{HCL}(200 \mathrm{mM}), \mathrm{MgCl}_{2} 6 \mathrm{H}_{2} \mathrm{O}(20 \mathrm{mM})$, NADP (2 mM), pH 7.4. Para a estabilização da reação, a placa foi colocada em Espectrofotômetro com temperatura controlada em torno de $37^{\circ} \mathrm{C}$ e leitura em 340 nM por 10 min. Logo após, a reação foi iniciada com a adição de $15 \mu \mathrm{L}$ do substrato que conteve TRIS HCL (200 mM), $\mathrm{MgCl}_{2} \cdot 6 \mathrm{H}_{2} \mathrm{O}(20 \mathrm{mM})$ e Malato (100 mM). A leitura foi realizada por 10 minutos (Bergmeyer, Bernet., 1974).

\subsubsection{ATP Citrato liase (ATPCL)}

Em placa de ELISA, foi pipetado primeiramente $15 \mu \mathrm{L}$ da amostra, em seguida $270 \mu \mathrm{L}$ da mistura de ensaio contendo TRIS HCL (200 mM), $\mathrm{MgCl}_{2} \cdot 6 \mathrm{H}_{2} \mathrm{O}(20 \mathrm{mM})$, $\mathrm{NADH}(0.4 \mathrm{mM})$, Citrato de Potássio (20 mM), DTT (1 mM), CoA (0.5 mM) e Malato Desidrogenase $1 \mathrm{U} / \mathrm{mL}, \mathrm{pH}$ 8.7. Para a estabilização da reação, a placa foi colocada em Espectrofotômetro com temperatura controlada em torno de $37{ }^{\circ} \mathrm{C}$. A leitura foi realizada a $340 \mathrm{nM}$ por 10 minutos. Após a estabilização, a reação foi iniciada com a adição de $15 \mu \mathrm{L}$ do substrato que conteve TRIS HCL (200 mM), $\mathrm{MgCl}_{2} 6 \mathrm{H}_{2} \mathrm{O}(20 \mathrm{mM})$ e ATP (60 mM), pH 8.7 . A leitura foi realizada por 10 min (Bergmeyer, Bernet., 1974). 


\subsubsection{Lactato Desidrogenase (LDH)}

Em placa de ELISA, foi pipetado primeiramente $10 \mu \mathrm{L}$ da amostra, em seguida $257.5 \mu \mathrm{L}$ da mistura de ensaio contendo TRIS HCL (120 mM), NADH (0.425 mM), Antimicina A (5 mg/mL de etanol), Triton X-100 1\%. Para a estabilização da reação, a placa foi colocada em Espectrofotômetro com temperatura em $25^{\circ} \mathrm{C}$, em $340 \mathrm{nM}$ por 10 min. Após a estabilização, a reação foi iniciada com a adição de $37.5 \mu \mathrm{L}$ do substrato que conteve Piruvato $(80 \mathrm{mM})$. A leitura foi realizada a $25^{\circ} \mathrm{C}, 340 \mathrm{nM}$ por 10 min. (Zammit, Newsholme, 1976) 


\section{$\underline{3.14 \text { LACTATO TECIDUAL }}$}

Para executar esta reação foram pipetados, em placa de Elisa, $6 \mu \mathrm{l}$ de amostra de tecido adiposo SC e RP, homogeneizados em Politron a $0{ }^{\circ} \mathrm{C}$, em tampão contendo sacarose $(0.25 \mathrm{M})$, EDTA $(1 \mathrm{mM})$, DTT $(1 \mathrm{mM})$, Leupeptina $(5 \mu \mathrm{M}) \mathrm{e}$ Aprotinina $(5 \mu \mathrm{M}), \mathrm{pH} 7.4$. O homogenato foi centrifugado a $7.000 \mathrm{RCF}$ a $0{ }^{\circ} \mathrm{C}$ por 5 min e os infranadantes livres de gordura foram cuidadosamente retirados e armazenados em freezer $-80^{\circ} \mathrm{C}$ até o momento de sua utilização. Além das amostras, o branco ou padrão foram pipetados no mesmo volume (6 $\mu \mathrm{l}$ ) e $300 \mu \mathrm{l}$ de reagente. A placa foi homogeneizada e em seguida mantida em espectrofotômetro a $37^{\circ} \mathrm{C}$ por 5 min, a absorbância foi determinada em $550 \mathrm{~nm}$. O kit utilizado foi o Lactato Enzimático Lab Test ${ }^{\circledR}$. 


\section{ANÁLISE ESTATÍSTICA}

Os resultados para a comparação das duas situações - Alimentado e Jejum foram analisados utilizando-se teste "t" de Student. Para o teste em que verificamos a influência de diferentes concentrações de glicose na lipogênese a partir do lactato, utilizamos ANOVA one-way e pós-teste de Tukey HSD (Honest Significant Diference). Em todas as análises, o nível de significância adotado foi de 0.05 e os valores foram representados como média \pm erro padrão da média (EPM). 


\section{RESULTADOS}

\subsection{PESO DOS ANIMAIS}

Para demonstrar a homogeneidade dos grupos estudados, apresentamos na Tabela 1, o peso dos animais antes de iniciar o tratamento com o jejum de $48 \mathrm{~h}$. Não houve diferenças estatísticas significativas entre os grupos (Al=342.6 $\pm 7.2 \mathrm{~g}$; J= $343.5 \pm 7.57 \mathrm{~g} ; \mathrm{p}>0.05[\mathrm{~N}=8]$ ). $\mathrm{O}$ jejum por $48 \mathrm{~h}$ reduziu em $12.40 \%$ o peso dos (Al $\left.>\mathrm{J} ;{ }^{*} p<0.05[\mathrm{~N}=7]\right)($ Tabela 1$)$.

\subsection{PESO DOS COXINS}

Após a eutanásia dos animais, os tecidos das diferentes regiões ( $S C$ e RP) foram retirados bilateralmente e o peso foi mensurado. A Tabela 1 mostra que o jejum levou à redução do coxim adiposo $\mathrm{SC}\left(\mathrm{Al}>\mathrm{J} ;{ }^{*} p<0.05[\mathrm{~N}=8]\right.$ ), o mesmo resultado, isto é, a diminuição da massa tecidual, não ficou evidente no coxim RP.

\subsection{VOLUME CELULAR DOS ADIPÓCITOS}

Após o isolamento dos adipócitos SC e RP (vide metodologia) de animais alimentados ou jejuados, seus diâmetros foram mensurados, os volumes foram calculados e conteúdo de células por ensaio determinados conforme Fine et al (1992). Nos adipócitos SC, ocorreram diferenças estatísticas relevantes (Al $>\mathrm{J} ;{ }^{*} p<0.05$ $[\mathrm{N}=8]$ ), e em contraste, nos adipócitos RP, isto não foi detectado. 


\subsection{INSULINA}

A insulinemia de animais em jejum $(0,12 \pm 0.09 \mathrm{ng} / \mathrm{ml})$ foi significativamente menor que a de animais alimentados $(1.37 \pm 0.24 \mathrm{ng} / \mathrm{ml})\left(\mathrm{Al}>\mathrm{J}\right.$; $\left.{ }^{*} \mathrm{p}<0.05[\mathrm{~N}=8]\right)$

\section{$\underline{5.5 \text { LEPTINA }}$}

A leptina é uma adipocina intimamente ligada a processos relacionados à fome e ao gasto energético. Seus níveis são proporcionais à massa adiposa corporal e sua síntese pelos adipócitos acentua-se no período pós-prandial. A leptinemia dos animais após $48 \mathrm{~h}$ de jejum (1.85 $\pm 0.43 \mathrm{ng} / \mathrm{ml})$ foi significativamente menor que a do grupo Al (4.42 $\pm 0.64 \mathrm{ng} / \mathrm{ml})$ (Al $>\mathrm{J} ;{ }^{*} p<0.05[\mathrm{~N}=8]$ ), indicando importante redução da adiposidade.

\section{$\underline{5.6 \mathrm{GLICOSE}}$}

A glicemia dos animais em jejum de $48 \mathrm{~h}$ também foi significativamente menor à dos alimentados $(\mathrm{Al}=142.8 \pm 4.53 \mathrm{mg} / \mathrm{dL} ; \mathrm{J}=98.41 \pm 4.62 \mathrm{mg} / \mathrm{dL})\left(\mathrm{Al}>\mathrm{J} ;{ }^{*} p<0.05\right.$ $[\mathrm{N}=6])$

\subsection{LACTATO}

Com o objetivo de avaliar se os níveis de lactato poderiam exercer alguma influência nos resultados obtidos dos ensaios biológicos de lipogênese, gliceroneogênese e de captação de lactato, os seus níveis plasmáticos foram determinados nos animais nas duas condições experimentais. Não houve diferenças estatísticas entre os grupos. ( $A l=10.02 \pm 0.90 \mathrm{mg} / \mathrm{dL} ; J=11.0 \pm 0.86 \mathrm{mg} / \mathrm{dL})(A l=\mathrm{J} ; p$ $>0.05[\mathrm{~N}=4])$. 


\subsection{BETA HIDROXIBUTIRATO (BHB)}

Para manter a oferta de substratos energéticos para o organismo durante 0 jejum, a cetogênese é estimulada no tecido hepático, o que, de fato, ocorreu e ficou comprovado pela determinação dos níveis plasmáticos de $\beta$-hidroxibutirato. Os corpos cetônicos (CC) são produzidos durante o jejum e a produção se intensifica à medida que este se prolonga, causando a cetose e elevação da excreção renal (cetonúria). Sendo assim, a medida do BHB é um bom representante do estado de jejum dos animais (Al= $\left.0.74 \pm 0.03 ; \mathrm{J}=1.22 \pm 0.06^{*} \mathrm{mmol} / \mathrm{L}\right)\left(\mathrm{Al}<\mathrm{J} ;{ }^{*} p<0.05[\mathrm{~N}=6]\right)$. 
Tabela 1 - Peso corporal, peso dos coxins, volume dos adipócitos e dosagens bioquímicas

\begin{tabular}{l|c|c|c}
\hline & Alimentado & Jejum 48h & $\mathrm{N}$ \\
\hline Peso dos Animais pré jejum (g) & $342.6 \pm 7.2$ & $343.5 \pm 7.57$ & 08 \\
\hline Peso dos Animais pós jejum (g) & --- & $296.6 \pm 5.7^{*}$ & 08 \\
\hline Peso coxim SC (g) & $2.10 \pm 0.46$ & $1.53 \pm 0.13^{*}$ & 08 \\
\hline Peso Coxim RP (g) & $2.13 \pm 0.62$ & $1.94 \pm 0.66$ & 08 \\
\hline Volume Adipócito SC (pL) & $121 \pm 10$ & $79 \pm 3^{*}$ & 08 \\
\hline Volume Adipócito RP (pL) & $225 \pm 21$ & $192 \pm 22$ & 08 \\
\hline Insulina Plasmática (ng/mL) & $1.37 \pm 0.24$ & $0,12 \pm 0.09^{*}$ & 08 \\
\hline Leptina Plasmática (ng/mL) & $4.42 \pm 0.64$ & $1.85 \pm 0.43^{*}$ & 08 \\
\hline Lactato Sérico (mg/dL) & $10.0 \pm 0.9$ & $11.0 \pm 0.9$ & 04 \\
\hline Glicose Plasmática (mg/dL) & $142.8 \pm 4.5$ & $98.41 \pm 4.6^{*}$ & 06 \\
\hline Beta Hidroxi butirato Plasmático (mmol/L) & $0.74 \pm 0.03$ & $1.22 \pm 0.06^{*}$ & 06 \\
\hline *Diferença estatistica significativa (p<0.05)
\end{tabular}

${ }^{\text {*Diferença estatística significativa }(p<0.05)}$ 


\subsection{ENSAIOS BIOLÓGICOS}

\subsubsection{Influência da Glicose na Incorporação de $\Gamma^{14} \mathrm{Cl-Acido} \mathrm{Lático} \mathrm{em} \mathrm{Adipócitos}$ Isolados de animais alimentados}

O teste de incorporação de lactato em lipídeos que se realiza em adipócitos isolados pode apresentar resultados diferentes se estas células forem incubadas em meios contendo ou não glicose. Para avaliar a importância da glicose sobre a resposta celular na lipogênese a partir do lactato, realizamos testes com diferentes concentrações de glicose ( $0 \mathrm{mM}, 1 \mathrm{mM}$ e $5 \mathrm{mM})$, na ausência ou presença de insulina (10 nM). Evidenciamos claramente, que a simples presença de glicose no meio de incubação do ensaio, seja na concentração $1 \mathrm{mM}$ ou $5 \mathrm{mM}$, foi um importante potencializador da capacidade de incorporação de lactato em lipídeos, em AG e em Glicerol de TG $\left(n=4 ; 0 m M<1 m M=5 m M,{ }^{*} p<0.001\right)$. Além disso, a presença de insulina mostrou-se capaz de estimular ainda mais a resposta lipogênica nos adipócitos de ambos os coxins gordurosos. Como a presença de glicose no meio de incubação do teste mostrou-se importante, e como as concentrações de 1 ou $5 \mathrm{mM}$ resultaram em respostas equivalentes do ponto de vista estatístico, nos testes subsequentes em que confrontamos as respostas de animais alimentados ou em jejum, adotamos a utilização de glicose $1 \mathrm{mM}$ nos meios de incubação. 

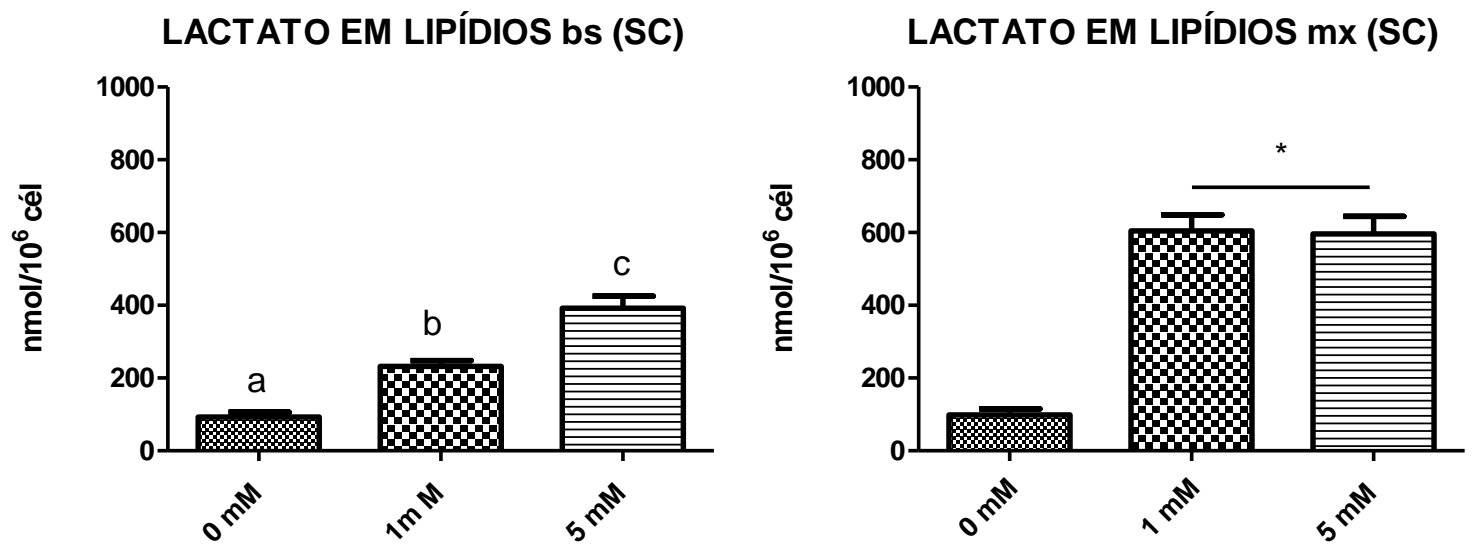

Figura 1A - Incorporação de ${ }^{14} \mathrm{C}$-Ácido Lático em Lipídios SC. A concentração $0 \mathrm{mM}$ reduziu a resposta lipogênica em comparação as demais concentrações de glicose utilizadas. Ausência de insulina (bs), os resultados mostram que a concentração crescente de glicose no meio de ensaio interfere na resposta celular $\left(0 \mathrm{mM}<1 \mathrm{mM}<5 \mathrm{mM} ;{ }^{*} \mathrm{p}<0.05[\mathrm{~N}=4]\right)$. Na presença de insulina $(\mathrm{mx})$, a ausência de glicose $(0 \mathrm{mM})$ levou a uma menor resposta em relação a 1 ou $5 \mathrm{mM}$. Não houve diferenças nas respostas frente às concentrações de 1 e $5 \mathrm{mM}$. Resultados expressos como média $\pm \operatorname{EPM}\left(0 \mathrm{mM}<1 \mathrm{mM}=5 \mathrm{mM} ;{ }^{*} \mathrm{p}<0.05[\mathrm{~N}=4]\right)$
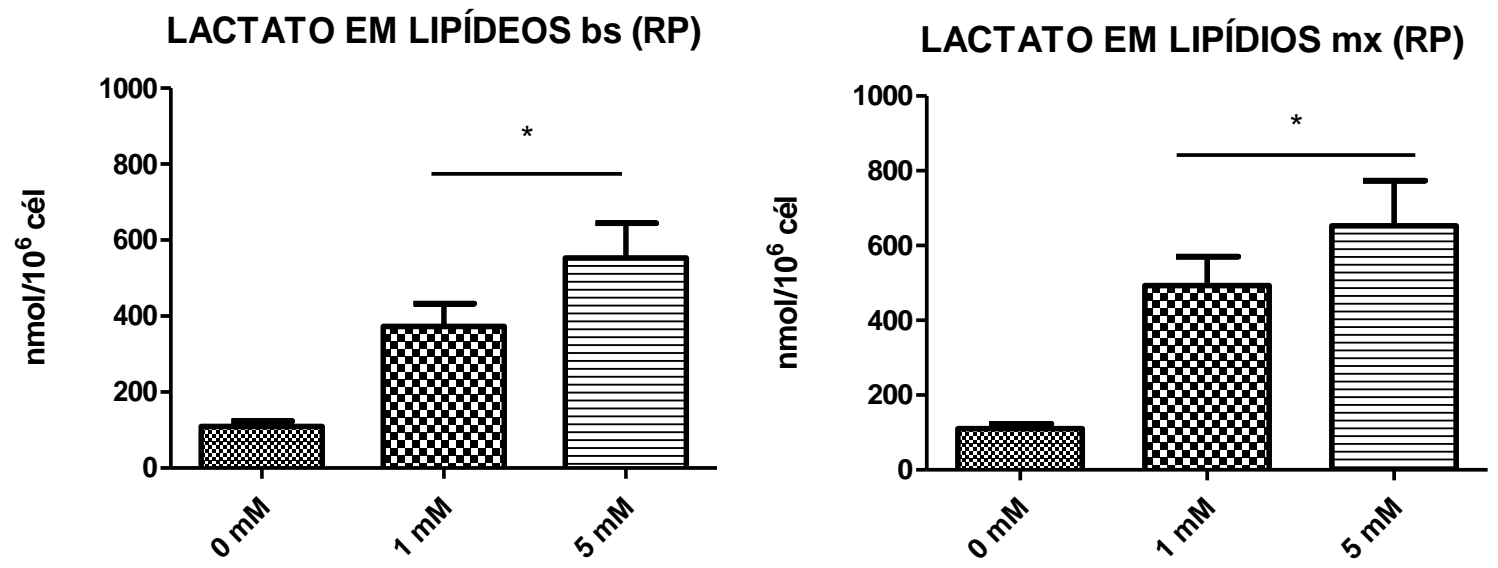

Figura 1B - Incorporação de ${ }^{14}$ C-Ácido Lático em Lipídios RP. Na ausência de glicose $(0 \mathrm{mM})$, a resposta celular foi inferior àquela em presença de glicose 1 ou $5 \mathrm{mM}$, tanto na ausência (bs) quanto na presença de insulina $10 \mathrm{nM}(\mathrm{mx})$. Resultados expressos como média $\pm \mathrm{EPM}(0 \mathrm{mM}<1 \mathrm{mM}=5 \mathrm{mM}$; $\left.{ }^{*} p<0.05[N=4]\right)$. 

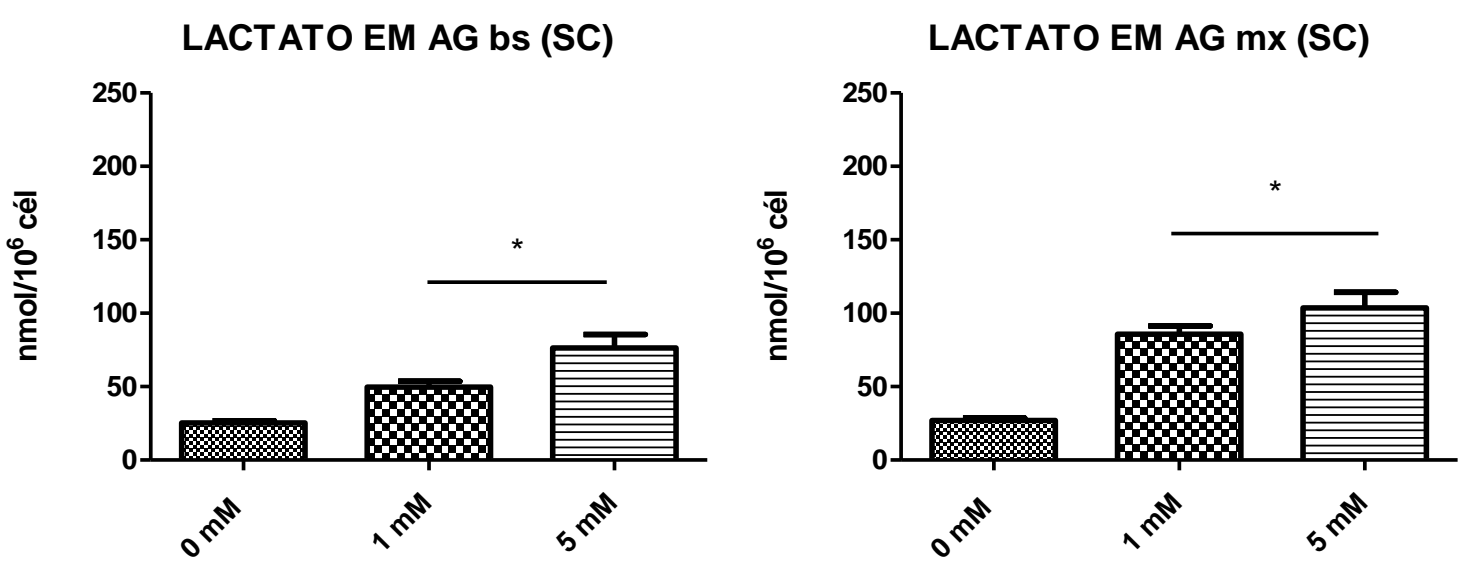

Figura 2A - Incorporação de ${ }^{14} \mathrm{C}$-Ácido Lático em Ácidos Graxos SC. A concentração $0 \mathrm{mM}$ mostrou-se com menor capacidade de incorporação quando comparada as demais. Resultados expressos como média \pm EPM $([\mathrm{N}=4] 0 \mathrm{mM}<1 \mathrm{mM}, 5 \mathrm{mM}$. * $\mathrm{p}<0.05)$. Na presença de insulina, a concentração $0 \mathrm{mM}$ mostrou-se com menor capacidade de incorporação quando comparada as demais, sendo que a concentração de $1 \mathrm{mM}$ não mostrou-se diferente a de $5 \mathrm{mM}$. ([N=4] $0 \mathrm{mM}<1 \mathrm{mM}, 5 \mathrm{mM}$. $\left.{ }^{*} \mathrm{p}<0.05\right)$.

LACT ATO EM AG bs (RP)

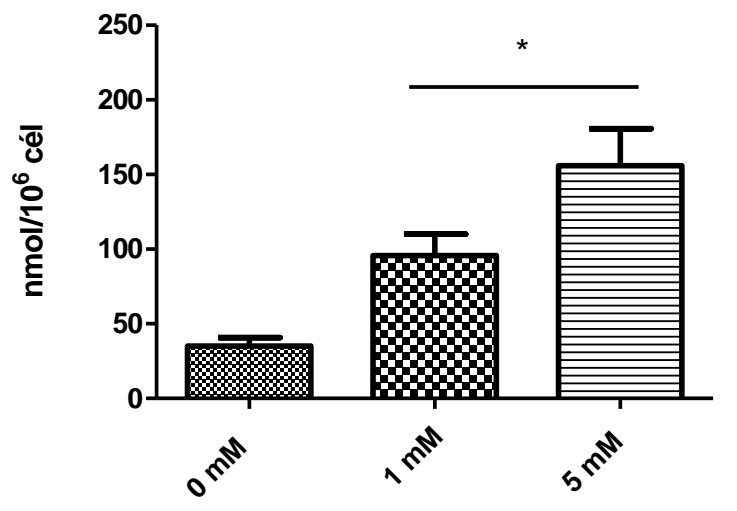

\section{LACTATO EM AG $\mathrm{mx}(\mathrm{RP})$}

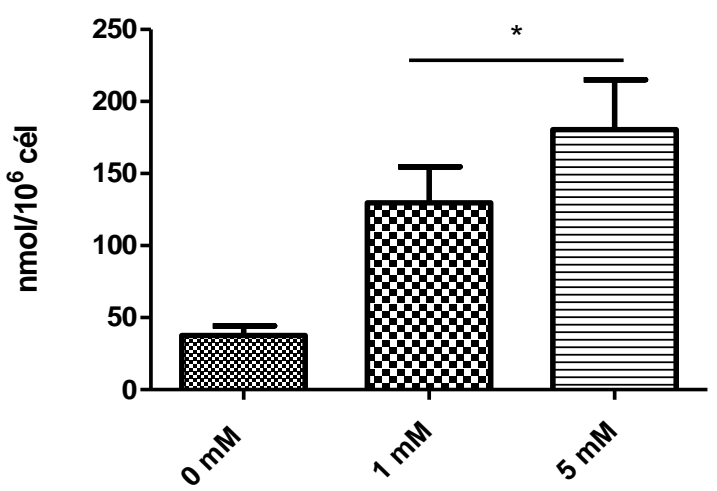

Figura 2B - Incorporação de ${ }^{14}$ C-Ácido Lático em Ácidos Graxos RP. A concentração 0 mM mostrou-se com menor capacidade de incorporação quando comparada as demais. Resultados expressos como média $\pm \mathrm{EPM}([\mathrm{N}=4] 0 \mathrm{mM}<1 \mathrm{mM}, 5 \mathrm{mM}$. * $\mathrm{p}<0.05)$. Na presença de insulina, a concentração $0 \mathrm{mM}$ mostrou-se com menor capacidade de incorporação quando comparada as demais. Além disso, a glicose em concentração $1 \mathrm{mM}$ não mostrou-se diferente a de $5 \mathrm{mM}$. ([N=4] $0 \mathrm{mM}<1 \mathrm{mM}, 5 \mathrm{mM}$. ${ }^{*} \mathrm{p}<0.05$ ) 

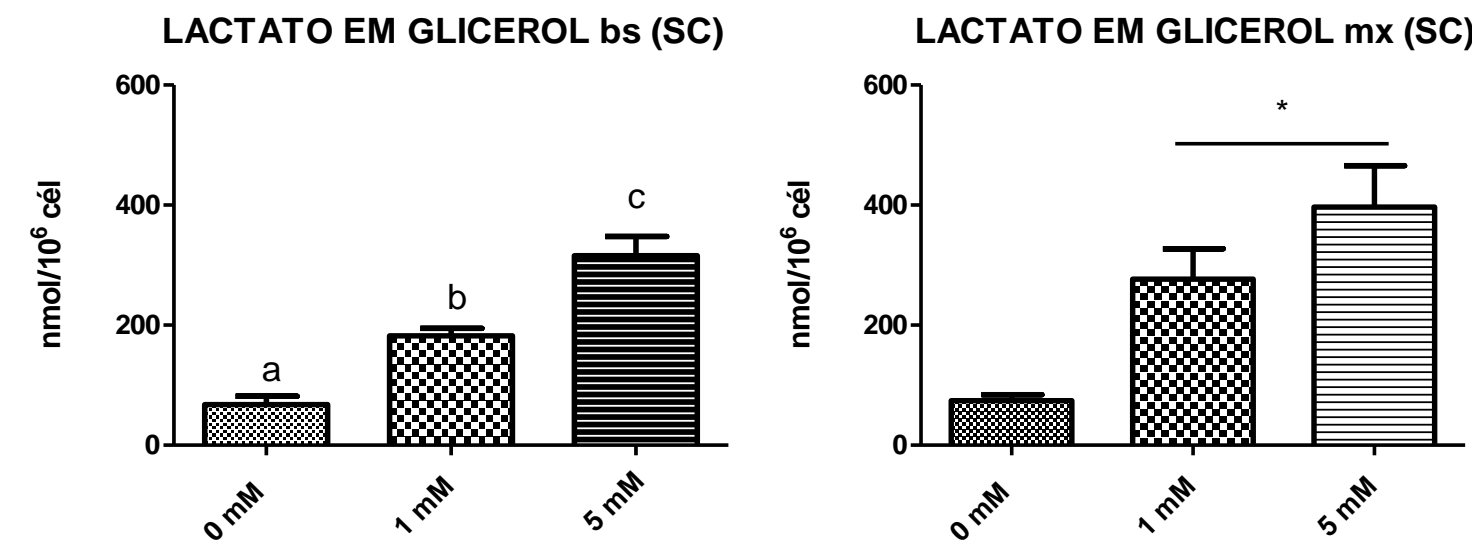

Figura 3A - Incorporação de ${ }^{14}$ C-Ácido Lático em Glicerol SC. Na ausência de insulina a capacidade de incorporação foi crescente às concentrações de glicose. Resultados expressos como média \pm EPM ([N=4] $\left.0 \mathrm{mM}<1 \mathrm{mM}<5 \mathrm{mM} ;{ }^{*} \mathrm{p}<0,05\right)$. Na presença de insulina, a concentração $0 \mathrm{mM}$ mostrou-se com menor capacidade de incorporação quando comparada a $1 \mathrm{mM}$ e $5 \mathrm{mM}$ Além disso, este testa com a concentração de glicose em $1 \mathrm{mM}$ não mostrou-se diferente a de $5 \mathrm{mM}$. ([N=4] $0 \mathrm{mM}<1 \mathrm{mM}$, $\left.5 \mathrm{mM} .{ }^{*} \mathrm{p}<0.05\right)$.

\section{LACTATO EM GLICEROL bS (RP)}
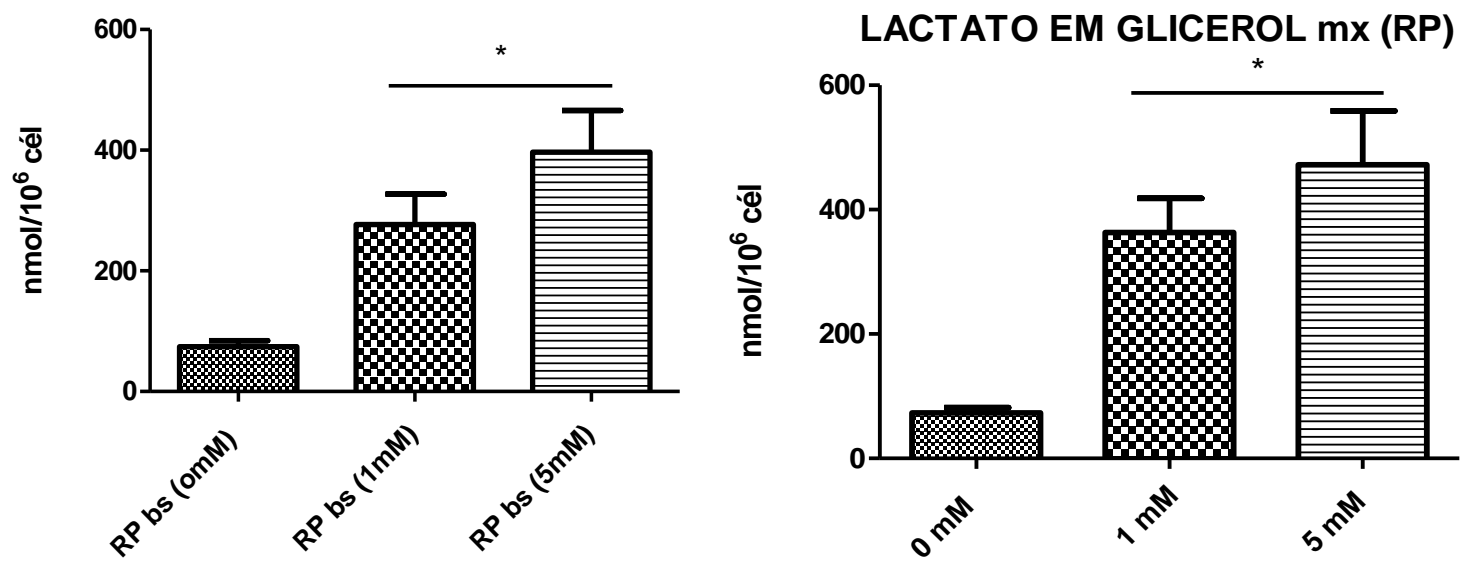

Figura 3B - Incorporação de ${ }^{14}$ C-Ácido Lático em Glicerol RP. A concentração $0 \mathrm{mM}$ mostrou menor capacidade lipogênica em comparação as demais concentrações de glicose utilizadas. Resultados expressos como média \pm EPM $\left([\mathrm{N}=4] 0 \mathrm{mM}<1 \mathrm{mM}, 5 \mathrm{mM}\right.$; $\left.{ }^{*} \mathrm{p}<0.05\right)$. Com o estímulo insulínico, a concentração de glicose $0 \mathrm{mM}$ mostrou reduzida capacidade lipogênica em comparação as demais concentrações de glicose utilizadas $\left([\mathrm{N}=4] 0 \mathrm{mM}<1 \mathrm{mM}, 5 \mathrm{mM} ;{ }^{*} \mathrm{p}<0.05\right)$ 


\subsubsection{Incorporação de $D-\left[U-{ }^{14} \mathrm{C}\right]$-Glicose e de ${ }^{14} \mathrm{C}$-Ácido Lático em Lipídios}

Glicose e Lactato são substratos importantes para a síntese de TAG no TA. A medida da incorporação destes em lipídios constitui-se em um índice da capacidade funcional da célula adiposa em realizar lipogênese.

$\mathrm{Na}$ figura $4 \mathrm{~A}$, observamos perda significativa da capacidade de incorporação de glicose em TAG no tecido SC de animais em jejum na ausência de estimulação por insulina em comparação aos alimentados ([N=8] $\left.{ }^{*} \mathrm{p}<0.05\right)$. Quando estimulados por insulina, estes adipócitos mostraram aumento da resposta, mas, ainda assim, a sua capacidade em animais $\mathrm{J}$ foi cerca de $38 \%$ menor que à dos $\mathrm{Al}\left([\mathrm{N}=8]^{*} \mathrm{p}<0.05\right)$.

No tecido RP, a medida de incorporação basal em lipídios a partir de glicose mostrou-se equivalente entre os grupos $([\mathrm{N}=8] \mathrm{p}>0.05)$. A resposta estimulada por insulina também foi menor na condição de jejum ([N=8] * $\mathrm{p}<0.05)$ (Figura 4B).

Quando o substrato utilizado foi o lactato, a incorporação em lipídeos foi menor nos animais submetidos ao jejum nos dois coxins (SC e RP), tanto na situação basal, quanto na estimulada por insulina ([N=8] * $\mathrm{p}<0.05)$ (Figuras $5 A$ e $5 B$ ). 

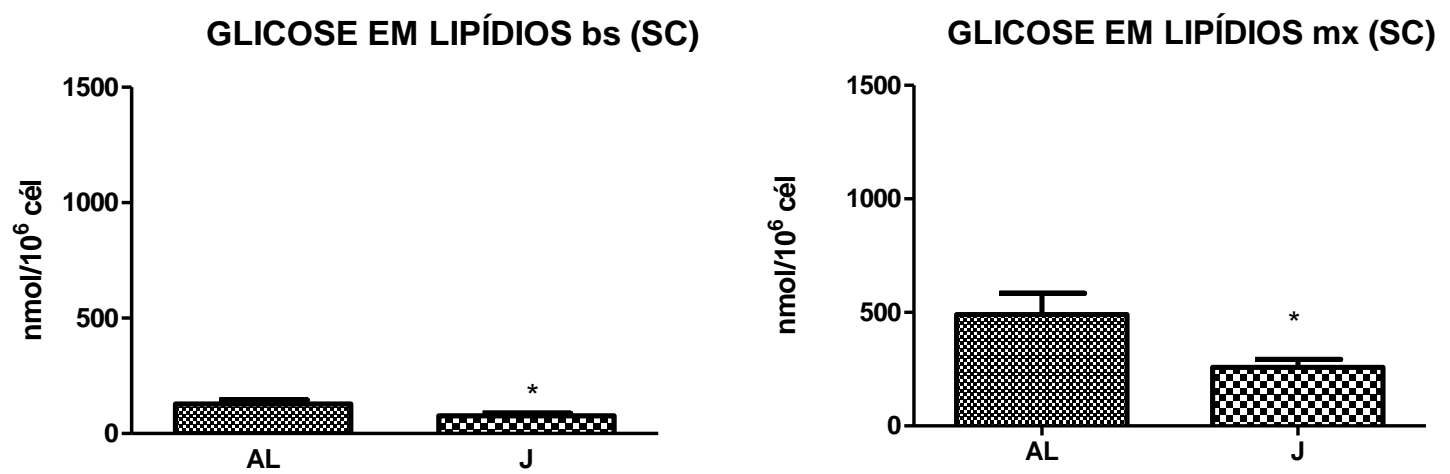

Figura 4A - Incorporação de D-[U- $\left.{ }^{14} \mathrm{C}\right]$-Glicose em Lipídios SC. O grupo Al apresentou maior capacidade comparada ao grupo $\mathrm{J}$, tanto em condições basais (bs) com em presença de insulina ( $\mathrm{mx}$ ). Os valores são expressos como média \pm EPM $\left(A l>J\right.$; $\left.{ }^{*} p<0.05[N=8]\right)$.
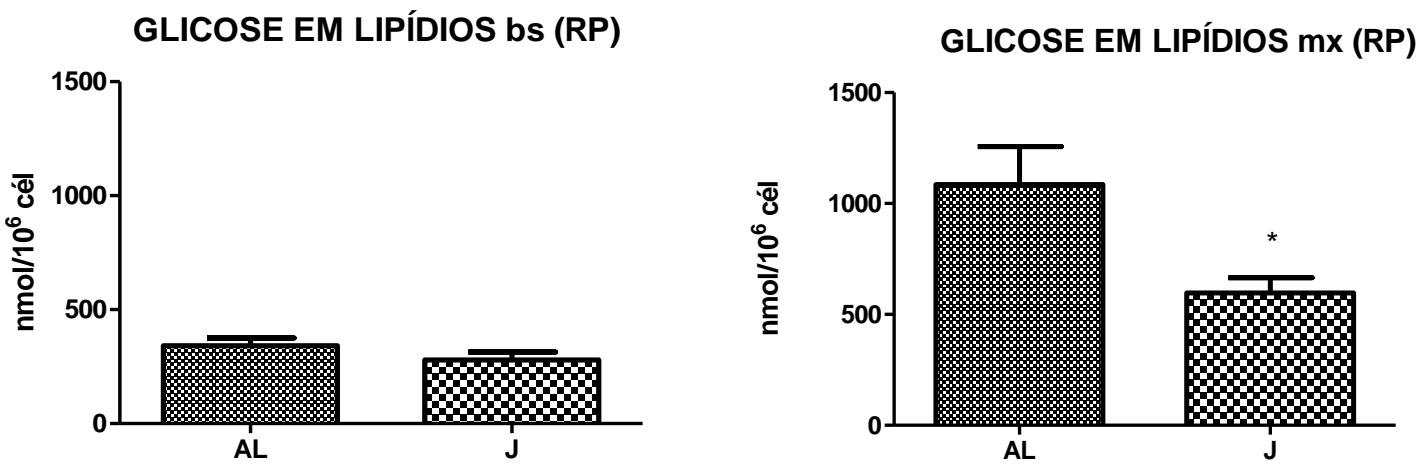

Figura 4B - Incorporação de D-[U- $\left.{ }^{14} \mathrm{C}\right]$-Glicose em Lipídios RP. Neste teste, não observamos diferenças significativas entre os animais alimentados e em jejum por $48 \mathrm{~h}$ na resposta basal (bs). Frente ao estímulo com insulina $(\mathrm{mx})$, o grupo Al apresentou maior atividade em relação a J. Os valores são expressos como média $\pm \operatorname{EPM}(\mathrm{Al}=\mathrm{J} ; \mathrm{p}>0.05[\mathrm{~N}=8])$. 
LACTATO EM LIPÍDIOS bs (SC)

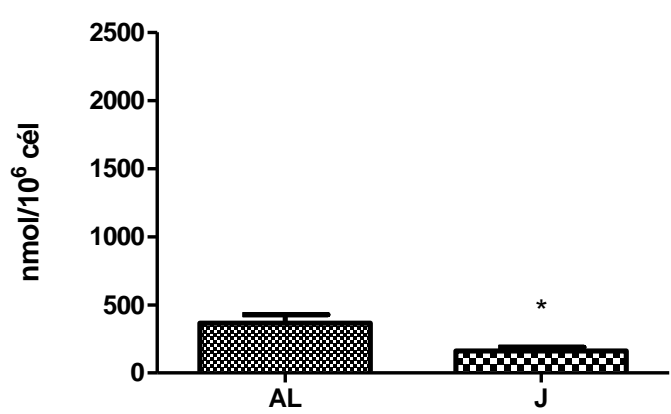

LACTATO EM LIPÍDIOS mx (SC)

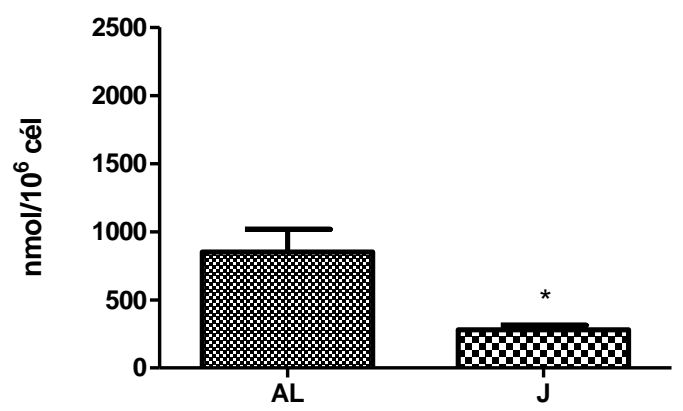

Figura 5A - Incorporação de ${ }^{14} \mathrm{C}$-Ácido Lático em Lipídios SC. O grupo Al apresentou maior capacidade em relação a J, na resposta basal (bs) e na estimulada por insulina (mx). Os valores são expressos como média $\pm \operatorname{EPM}\left(\mathrm{Al}>\mathrm{J} ;{ }^{*} \mathrm{p}<0.05[\mathrm{~N}=8]\right)$.

LACTATO EM LIPÍDIOS bs (RP)

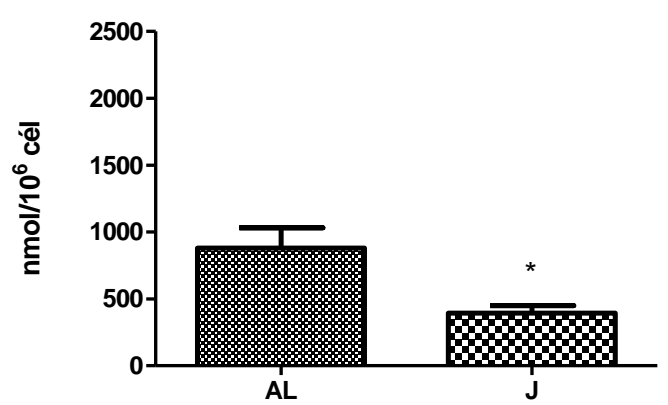

LACTATO EM LIPÍDIOS mx (RP)

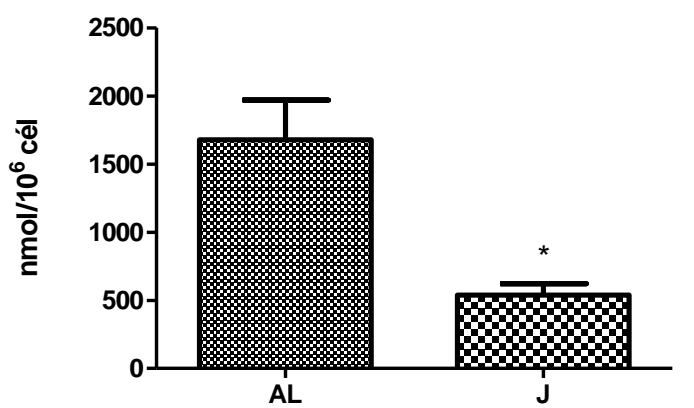

Figura 5B - Incorporação de ${ }^{14} \mathrm{C}$-Ácido Lático em Lipídios RP. Basicamente, o mesmo padrão visto para a gordura SC se repetiu para a RP. Os valores expressos como média \pm EPM ( $\mathrm{Al}>\mathrm{J}$; ${ }^{*} \mathrm{p}<0.05[\mathrm{~N}=8]$ ). 


\subsubsection{Incorporação de D-[U- ${ }^{14} \mathrm{Cl}$-Glicose e de ${ }^{14} \mathrm{C}$-Ácido Lático em Ácidos Graxos}

Para a execução desta etapa, o triacilglicerol previamente extraído no teste anterior foi submetido a uma hidrólise alcoólica em presença de $\mathrm{KOH}(40 \%)$. Com esta manobra, o resíduo ácido graxo do TAG foi coletado e analisado. Com isso, visualizou-se e quantificou-se a rota preferencial (seja para AG ou Glicerol) do substrato para síntese de TG, após sua captação pela célula.

No ensaio em que ${ }^{14} \mathrm{C}$-glicose foi o substrato, a resposta basal no tecido SC foi similar nas duas condições (jejum e estado alimentado). No entanto, quando estimulados com insulina, os adipócitos dos animais jejuados responderam menos intensamente que os de alimentados $\left([\mathrm{N}=8]^{*} \mathrm{p}<0.05\right.$ ) (Figura 6A). No tecido $\mathrm{RP}$, as respostas celulares, tanto na ausência ou presença de estimulo com insulina, se apresentaram reduzidas no grupo $\mathrm{J}$ em relação ao $\mathrm{AL}\left(\mathrm{N}=8,{ }^{*} \mathrm{p}<0.05\right)$ (Figura $\left.6 \mathrm{~B}\right)$.

No que se refere à utilização do ${ }^{14} \mathrm{C}$-lactato como substrato, o jejum revelouse uma condição inibidora nos dois coxins adiposos estudados (SC e RP) tanto na ausência (bs) quanto frente ao estímulo com insulina ( $\mathrm{mx}$ ) (Al $\left.>\mathrm{J}[\mathrm{N}=8]^{*} \mathrm{p}<0.05\right)$, como mostram as figuras 7A e 7B. 
GLICOSE EM AG bs (SC)
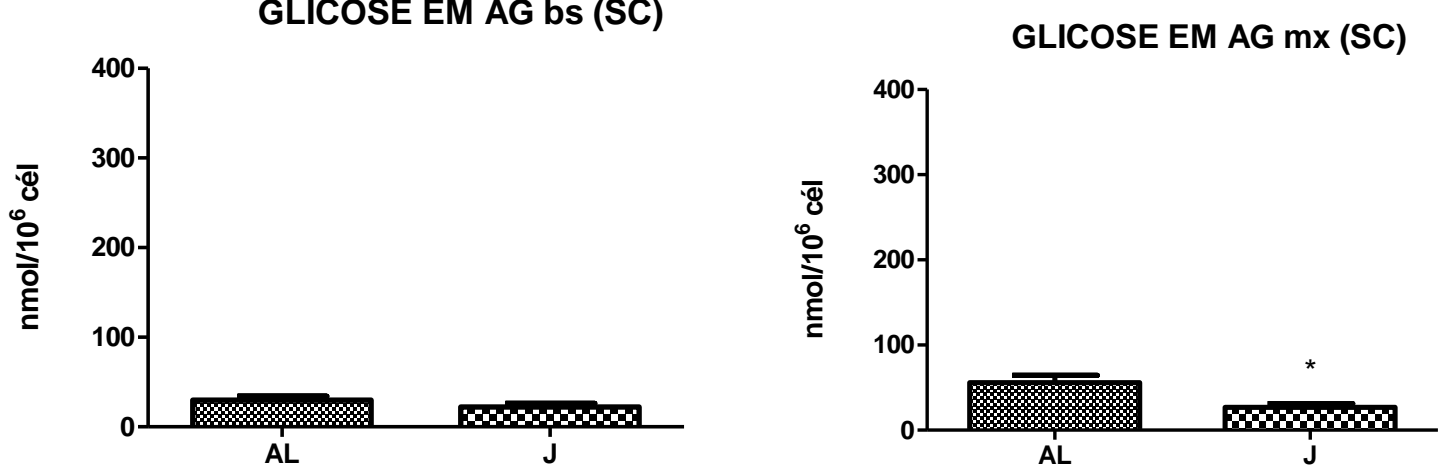

Figura 6A - Incorporação de D-[U- $\left.{ }^{14} \mathrm{C}\right]-$ Glicose em AG SC. Não observamos diferenças estatísticas entre os grupos estudados. Frente ao estímulo insulínico $(\mathrm{mx})$, o grupo Al apresentou maior capacidade comparada ao grupo J. Os valores são expressos como média \pm EPM (Al vs J [N=8]; $\left.{ }^{*} p<0.05\right]$ )

GLICOSE EM AG bs (RP)

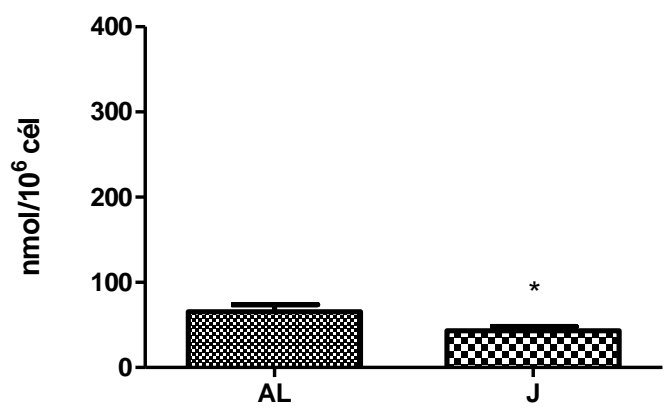

GLICOSE EM AG mx (RP)

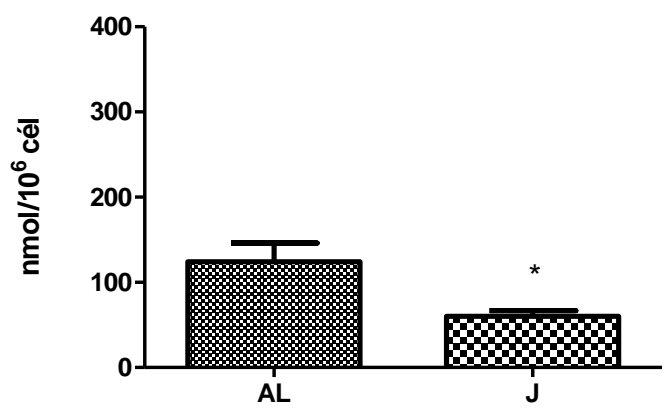

Figura 6B - Incorporação de D-[U- ${ }^{14}$ C]-Glicose AG RP. O grupo Al apresentou maior capacidade comparada ao grupo J, tanto na ausência (bs) quanto na presença de insulina $(\mathrm{mx})(10 \mathrm{nM})$. Os valores são expressos como média \pm EPM (Al vs $\left.\mathrm{J}[\mathrm{N}=8]{ }^{*} \mathrm{p}<0.05\right]$ ) 
LACTATO EM AG bs (SC)

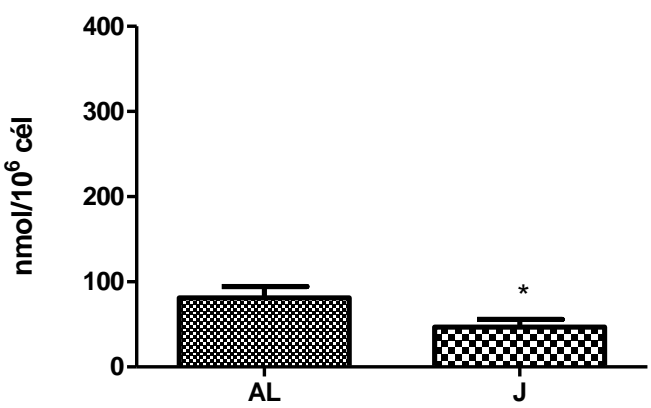

LACTATO EM AG $\mathrm{mx}(\mathrm{SC})$

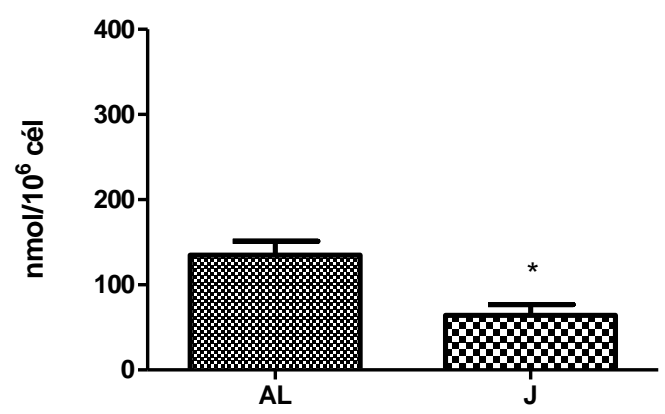

Figura 7A - Incorporação ${ }^{14} \mathrm{C}$-Ácido Lático em AG. No tecido SC, tanto na ausência (bs), quanto na presença de insulina ( $\mathrm{mx}$ ), o grupo $\mathrm{Al}$ apresentou maior capacidade comparada ao grupo J. Os valores são expressos como média \pm EPM $\left(\mathrm{Al}>\mathrm{J}[\mathrm{N}=8]{ }^{*} \mathrm{p}<0.05\right)$
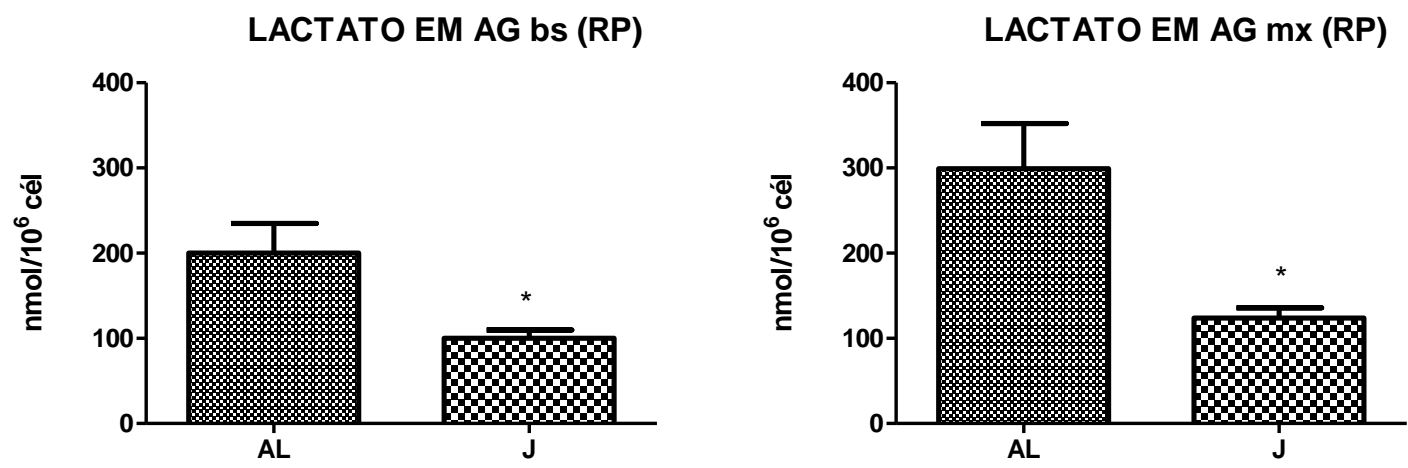

Figura 7B - Incorporação ${ }^{14} \mathrm{C}$-Ácido Lático em AG. No tecido RP, na situação basal (bs) ou frente ao estímulo com insulina $(\mathrm{mx})$, observamos maior capacidade em realizar lipogênese no grupo Al. Os valores são expressos como média \pm EPM $\left(\mathrm{Al}>\mathrm{J}[\mathrm{N}=8]^{*} \mathrm{p}<0.05\right)$. 
5.9.4 Incorporação de $D$-[U- $\left.{ }^{14} \mathrm{C}\right]$-Glicose e ${ }^{14} \mathrm{C}$-Ácido Lático em Glicerol de Triglicérides

Estes dados foram obtidos pela diferença entre a Incorporação de D-[U- $\left.{ }^{14} \mathrm{C}\right]-$ Glicose ou ${ }^{14} \mathrm{C}$-Ácido Lático em Lipídios e de D-[U- $\left.{ }^{14} \mathrm{C}\right]$-Glicose ou ${ }^{14} \mathrm{C}$-Ácido Lático em Ácidos Graxos. A partir daí, obtivemos o grau de incorporação de D-[U- $\left.{ }^{14} \mathrm{C}\right]-$ Glicose no resíduo Glicerol de Triglicérides.

Quando a glicose foi utilizada como traçador desta via metabólica, não observamos diferenças entre $\mathrm{Al}$ e $\mathrm{J}$, na situação basal, em ambos os tecidos ([N=8] $\left.{ }^{*} p<0.05\right)$. No entanto, quando estimulados por insulina, os adipócitos dos animais submetidos ao jejum de $48 \mathrm{~h}$ mostraram ter menor capacidade de incorporação em glicerol (Figuras $8 \mathrm{~A}$ e $8 \mathrm{~B}$ ) (Al vs $\left.\mathrm{J}[\mathrm{N}=8]{ }^{*} \mathrm{p}<0.05\right)$.

Com relação ao lactato, verificou-se que a gliceroneogênese como fonte de glicerol-3-P para a lipogênese apresentou diferenças significativas entre jejum e estado alimentado nos diferentes tecidos, estimulados ou não por insulina. O jejum diminuiu a capacidade se comparado ao $\mathrm{Al}$, tanto na ausência, quanto na presença de insulina $\left([\mathrm{N}=8]^{*} \mathrm{p}<0.05\right)$ (Figuras 9A e 9B). 
GLICOSE EM GLICEROL bs (SC)

GLICOSE EM GLICEROL mx (SC)
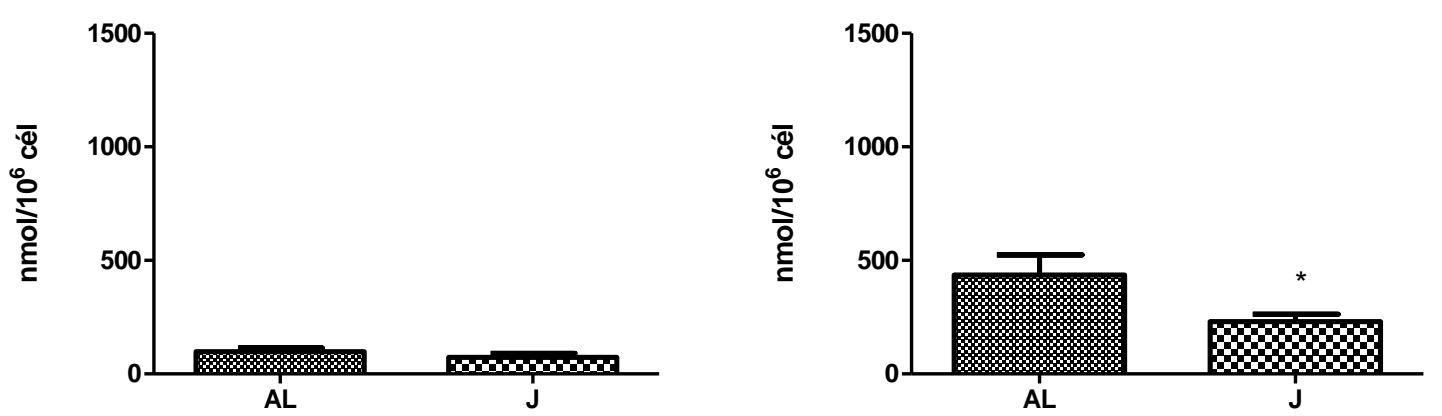

Figura 8A - Incorporação de D-[U- ${ }^{14}$ C]-Glicose em Glicerol SC. Na ausência de insulina (bs) não observamos diferenças significativas entre os grupos estudados. Os valores são expressos como média $\pm E P M$ (Al vs J [N=8]; * $\mathrm{p}>0.05]$ ). Após o estímulo máximo com insulina $(\mathrm{mx})$, os animais do grupo $\mathrm{Al}$ responderam com maior intensidade ao teste (Al vs J $[\mathrm{N}=8]^{*} \mathrm{p}<0.05$ ).
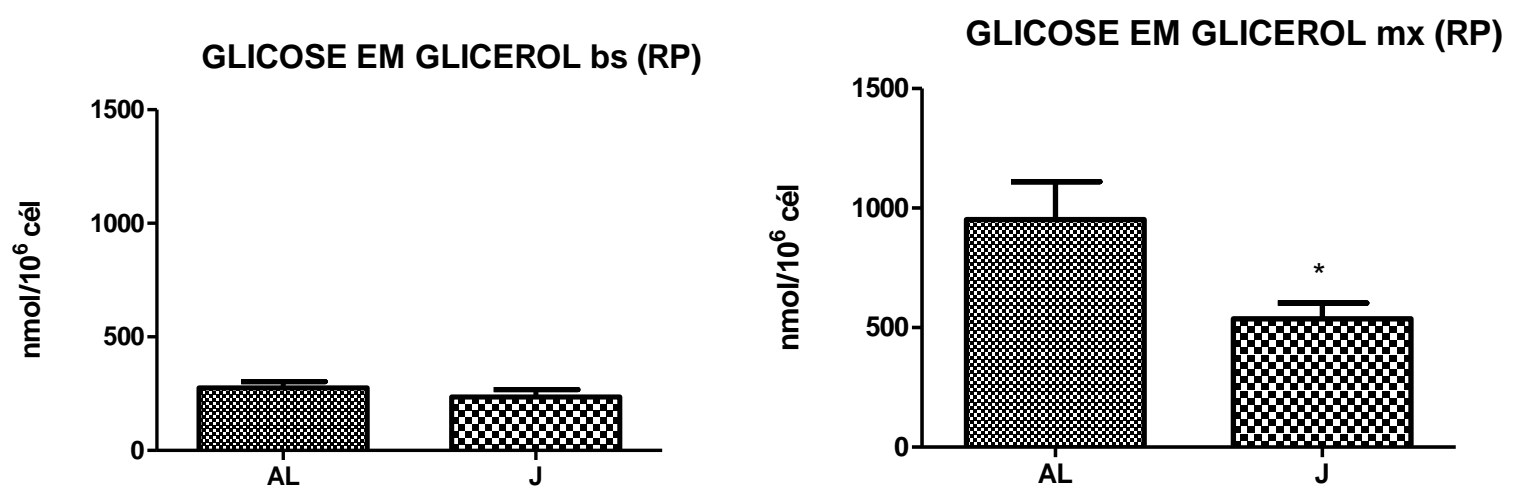

Figura 8B - Incorporação estimulada por insulina de D-[U- ${ }^{14}$ C]-Glicose Glicerol RP. Assim como no tecido $\mathrm{SC}$ na ausência de insulina (bs), não observamos diferenças significativas entre os grupos $\mathrm{Al}$ e J. Os valores são expressos como média $\pm \operatorname{EPM}(\mathrm{Al}$ vs $\mathrm{J}[\mathrm{N}=8]$ * $\mathrm{p}>0.05$. Porém, o estímulo com insulina $(\mathrm{mx})$ promoveu aumento na incorporação no grupo Al (Al vs J $\left.[\mathrm{N}=8]^{*} \mathrm{p}<0.05\right)$. 

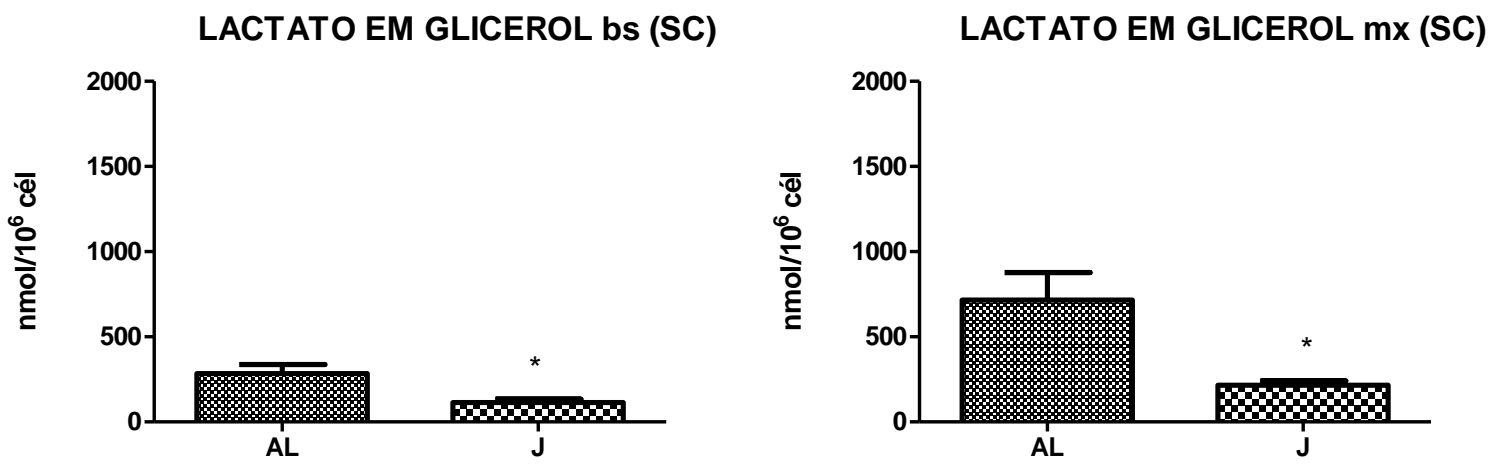

Figura 9A - Incorporação de ${ }^{14}$ C-Ácido Lático em Glicerol SC. Tanto na ausência (bs), quanto na presença de insulina (mx), o grupo $\mathrm{J}$ mostrou menor capacidade de incorporação quando comparada ao grupo Al. Os valores são expressos como média \pm EPM (Al vs J [N=8] * $p<0.05)$.

LACTATO EM GLICEROL bs (RP)

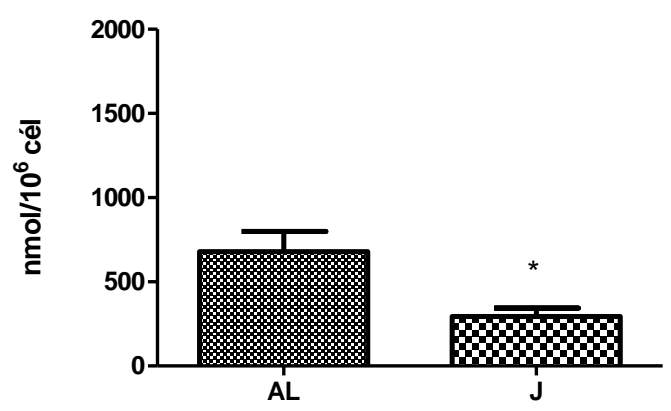

LACTATO EM GLICEROL mx (RP)

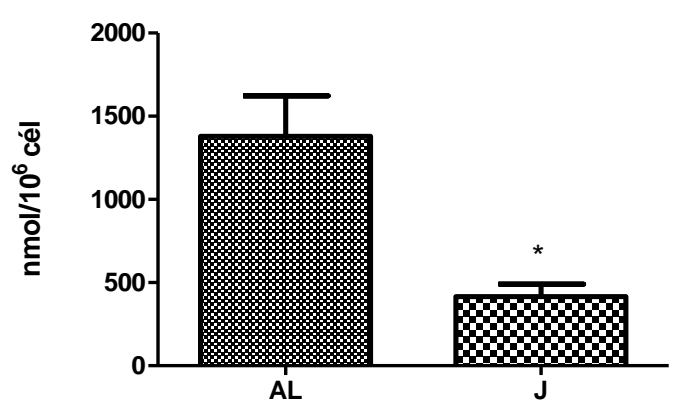

Figura 9B - Incorporação de ${ }^{14} \mathbf{C}$-Ácido Lático em Glicerol RP. O grupo J apresentou menor capacidade comparada ao grupo Al tanto na ausência (bs) quanto na presença de insulina (10 nM) (mx). Os valores são expressos como média $\pm \operatorname{EPM}\left(\mathrm{Al}\right.$ vs $\left.\mathrm{J}[\mathrm{N}=8]^{*} \mathrm{p}<0.05\right)$. 


\subsubsection{Captação de ${ }^{14}$ C-Ácido Lático em Adipócitos Isolados}

Diante das evidências encontradas a respeito da presença da glicose como uma agente potencializadora da lipogênese a partir do lactato, julgamos conveniente avaliar se o resultado obtido deveu-se ao metabolismo intracelular ou à uma etapa anterior, como no transporte de lactato para o interior da célula. Além disso, verificamos também, o efeito da insulina $(10 \mathrm{nM})$ e do jejum neste processo.

Ao completar 12 semanas, um grupo de ratos machos Wistar alimentados e outro grupo de ratos submetidos ao jejum por $48 \mathrm{~h}$, foram levados à eutanásia por decapitação cervical e os TAs dos coxins SC e RP foram coletados para a análise biológica ex vivo.

As amostras de adipócitos isolados dos tecidos SC e RP foram ensaiadas em presença ou ausência de glicose ( 0 e $4 \mathrm{mM}$ ) ou de insulina (0 e $10 \mathrm{nM})$.

Nos adipócitos do tecido SC na ausência de glicose, incubados com ou sem insulina, não observamos diferenças estatísticas na captação medida entre células provenientes de animais alimentados ou em jejum (Al vs $\mathrm{J}$; $p>0.05$ [N=4]) (Figura 10A). Em contraste, na presença de glicose, o jejum reduziu a capacidade de captação de lactato quando comparado aos animais alimentados, nas duas situações (com e sem insulina). (Al $>\mathrm{J} ;{ }^{*} \mathrm{p}<0.05$ [N=4]) (Figura 10B). Diante disso, observamos que jejum reduz de forma importante a captação de lactato pelas células adiposas.

No tecido visceral RP, na ausência de glicose, não houve diferenças significativas na captação da lactato pelos adipócitos nas duas condições experimentais (jejum ou alimentado). Por outro lado, na presença de glicose (bs) observamos menor capacidade de captação do ácido lático no jejum (Al vs J; 
$\left.{ }^{*} \mathrm{p}<0.05[\mathrm{~N}=4]\right) .0$ mesmo resultado não foi evidenciado na presença de insulina (mx) (Figura 11B). 

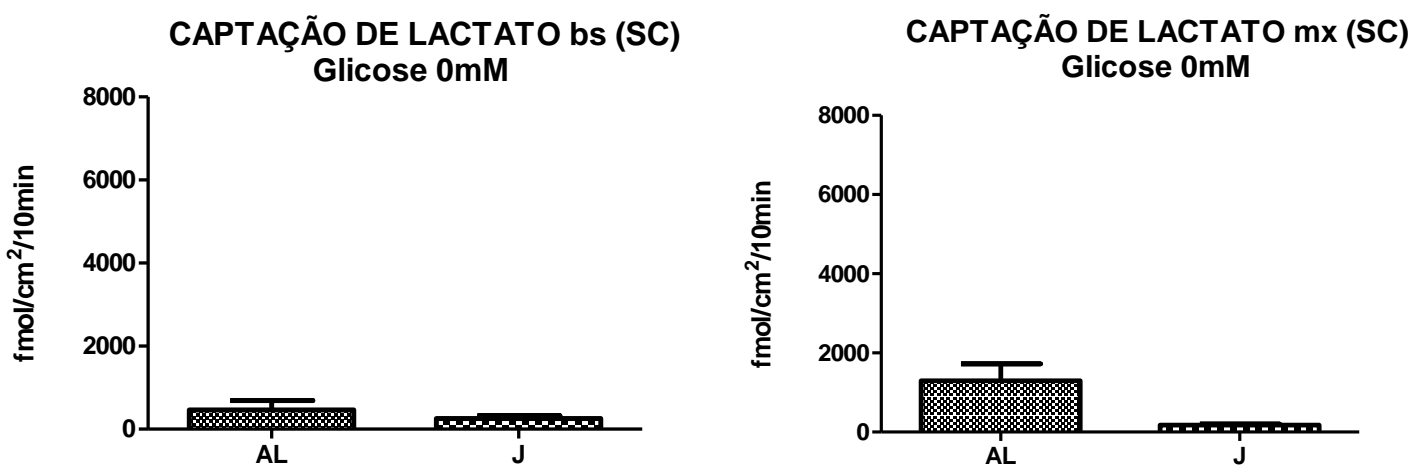

Figura 10A - Captação de ${ }^{14}$ C-Ácido Lático por adipócitos isolados SC, glicose $0 \mathrm{mM}$. Na ausência de glicose, tanto na presença $(\mathrm{mx})$ quanto na ausência de insulina (bs), não observamos diferenças estatísticas entre os grupos estudados. Resultados expressos como média \pm EPM (Al vs J; $\mathrm{p}>0.05[\mathrm{~N}=4])$
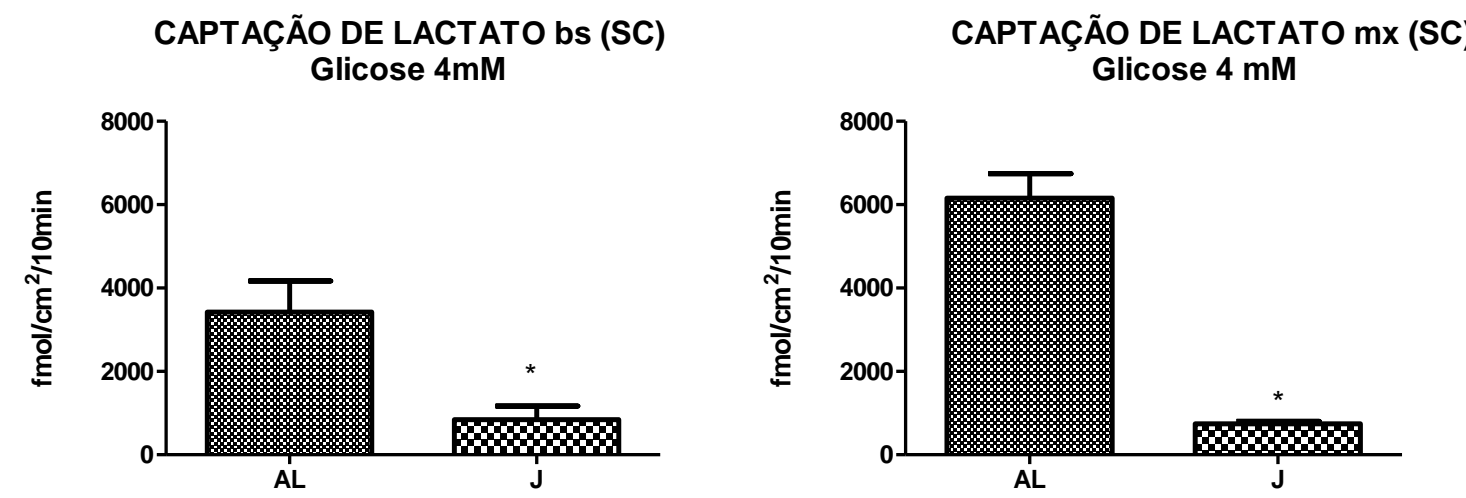

Figura 10B - Captação de ${ }^{14}$ C-Ácido Lático por adipócitos isolados SC, glicose 4 mM . No teste executado com $4 \mathrm{mM}$ de glicose, verificamos que a captação de lactato é significativamente menor no grupo $\mathrm{J}$ do que no grupo $\mathrm{Al}$, tanto na ausência (bs) quanto na presença de insulina $(\mathrm{mx})$ (10 $\mathrm{nM}$ ). Resultados expressos como média \pm EPM (Al vs $\mathrm{J} ;{ }^{*} \mathrm{p}<0.05[\mathrm{~N}=4]$ ) 
CAPTAÇÃO DE LACTATO bs (RP) Glicose 0 mM

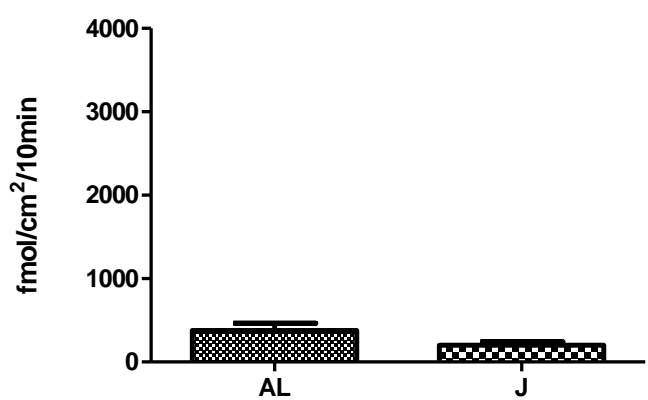

CAPTAÇÃO DE LACTATO mx (RP)

Glicose $0 \mathrm{mM}$

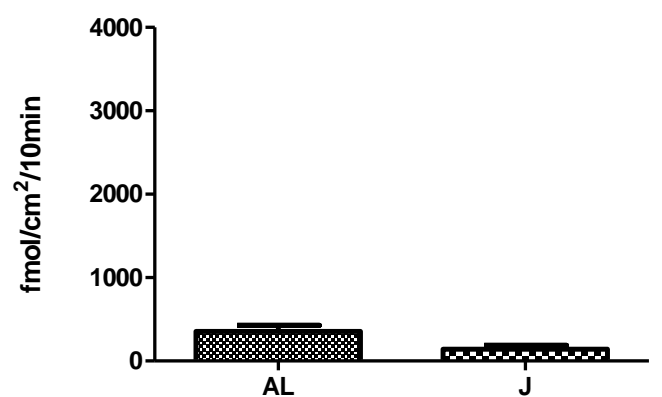

Figura 11A - Captação de ${ }^{14} \mathrm{C}$-Ácido Lático por adipócitos isolados RP, glicose (0 mM).Não observamos diferenças estatisticamente significativas quando o teste foi realizado na ausência de glicose, além disso, a adição de insulina (mx) não exerceu qualquer efeito sobre o teste. Resultados expressos como média \pm EPM (Al vs $\mathrm{J} ; \mathrm{p}>0.05[\mathrm{~N}=4]$ )
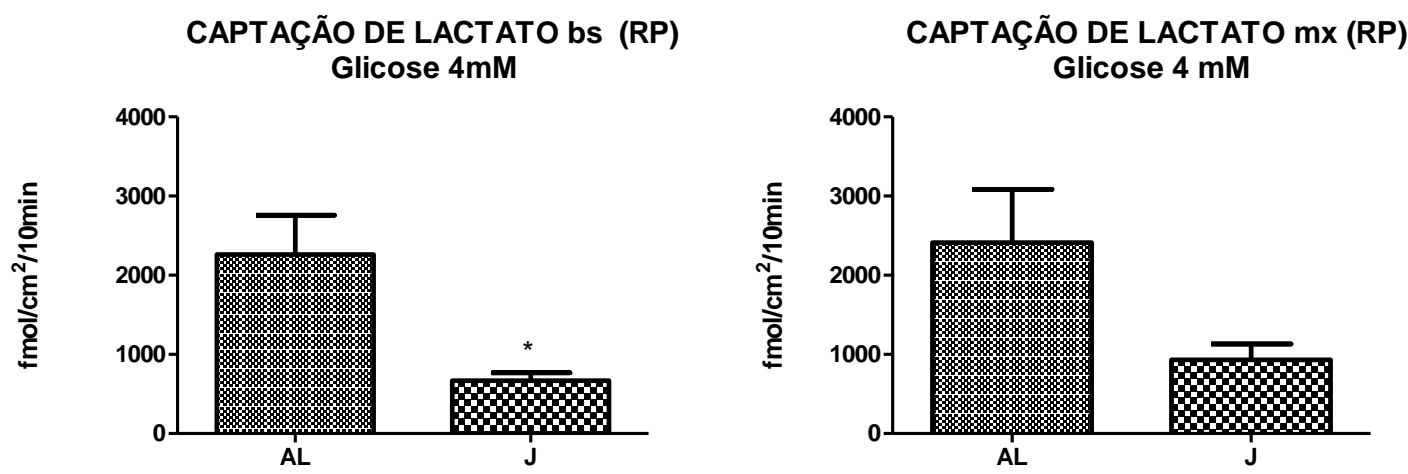

Figura 11B - Captação de ${ }^{14} \mathrm{C}$-Ácido Lático por adipócitos isolados RP, glicose (4 mM). Na situação basal (bs), o grupo J mostrou menor capacidade de captação (Al vs J [N=4; * $\mathrm{p}<0.05]$ ), no entanto, após estímulo com insulina (mx), não observamos o mesmo comportamento. (Al vs $\mathrm{J}[\mathrm{N}=4] \mathrm{p}>0.05]$ ) 


\section{$\underline{\text { 5.9.6 Destino dos Substratos }}$}

Nas figuras abaixo, estão colocados os resultados em porcentagem referentes ao direcionamento dos substratos glicose e lactato para a geração de glicerol-3-P, isto é, eles descrevem qual o montante de glicose ou lactato que foi direcionado para a síntese de glicerol e de ácido graxo, considerando como 100\% o total que foi utilizado para a síntese de TAGs.

Com relação à glicose (SC) na ausência de insulina (bs), em números absolutos, a incorporação em lipídeos totais ficou em torno de 128,5 (nmol.106 céls) e destes, 98,53 (nmol.10-6 céls) foram direcionados para a glicerol-3-P, ou seja no estado alimentado $74,8 \%$ da glicose foi direcionada para a síntese de glicerol. No jejum, reduziu-se essa proporção para síntese de ácidos graxos, ao mesmo tempo em que aumentou o índice (93,8\%) de direcionamento para glicerol-3-P. Quando estimulado por insulina, em animais alimentados, evidenciamos aumento acentuado da destinação de glicose para a síntese de ácidos graxos em detrimento da síntese de glicerol, enquanto que no jejum, a insulina pareceu não influenciar no direcionamento deste substrato (Figura 12A).

Quando o substrato utilizado foi o lactato (na gordura SC) verificamos que a porcentagem direcionada para a síntese de glicerol praticamente não foi alterada e se manteve entre 76 (na situação basal) e $81 \%$ (estimulada por insulina) no estado alimentado e entre 68 (basal) e 77\% no jejum (estimulada) (Figura 12B).

No tecido RP, os adipócitos dos animais alimentados direcionaram aproximadamente $44 \%$ do lactato para a síntese de glicerol, enquanto que no jejum, elevou-se para $72.5 \%$. Na presença de insulina, observamos o mesmo padrão de 
destinação observado na condição basal e as proporções se mantiveram praticamente inalteradas. (Figura 13B). 

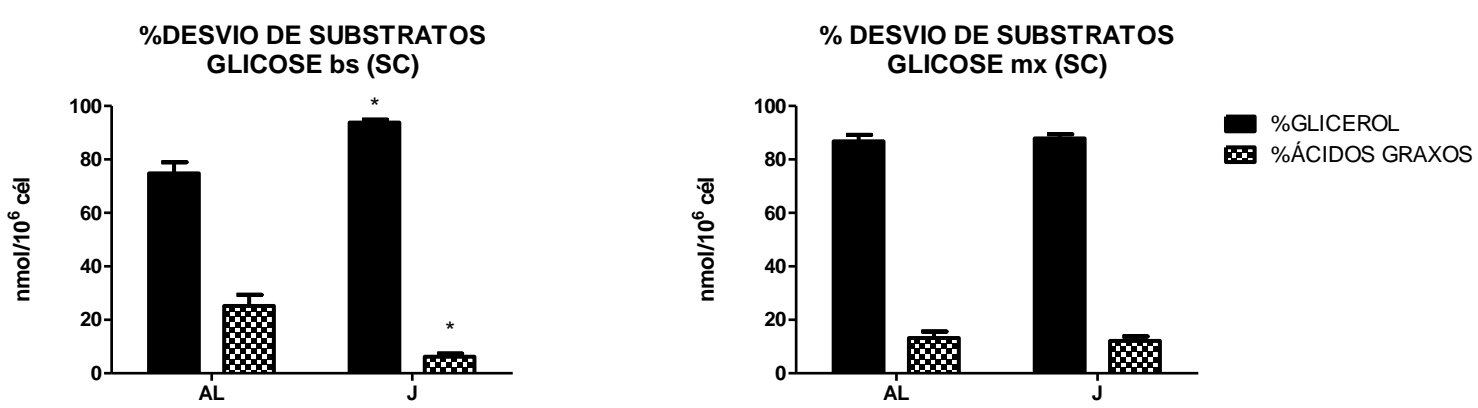

Figura 12A. Destino metabólico da glicose na lipogênese em gordura SC. Em animais alimentados e jejuados, na ausência de insulina (bs), os adipócitos direcionaram a maior parte de glicose para a síntese de glicerol, embora nos animais jejuados esta medida tenha se mostrado significativamente maior em comparação aos alimentados (Al vs $\mathrm{J},{ }^{*} \mathrm{p}<0.05[\mathrm{~N}=8]$ ). Após 0 estímulo com insulina $(\mathrm{mx})$, observamos aumento do direcionamento da glicose para a síntese de glicerol em animais alimentados e de ácidos graxos nos animais em jejum. Com isto, na presença de insulina, não observamos diferenças significativas entre as diferentes condições estudadas. Resultados apresentados como média \pm EPM (Al vs $\mathrm{J} p>0.05$, [N=8]).
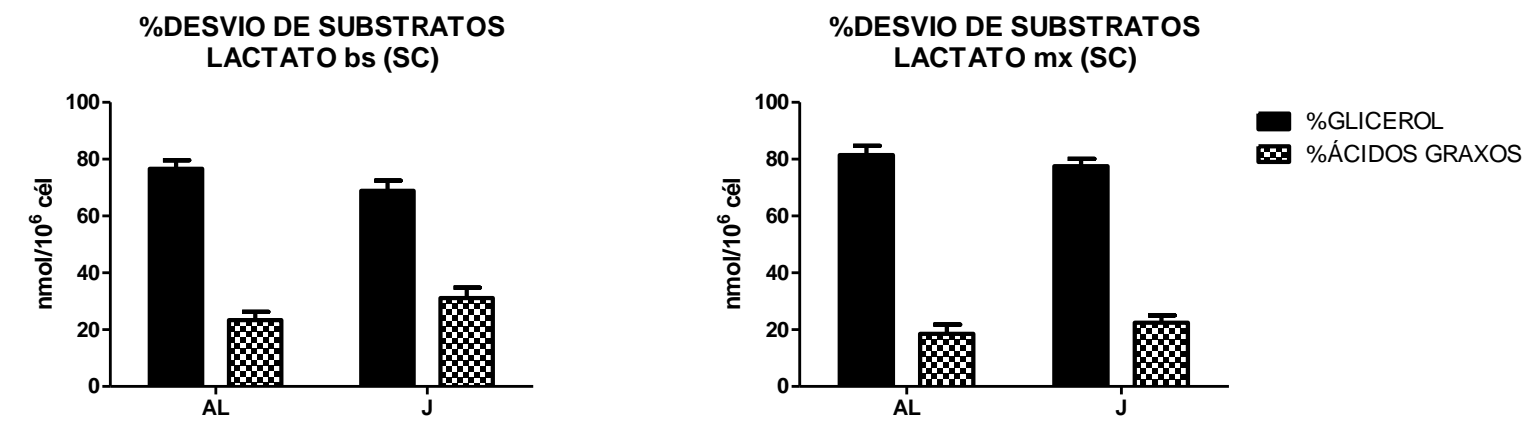

Figura 12B. Destino metabólico do ácido lático na lipogênese na gordura SC. No que se refere ao destino metabólico do lactato, não observamos diferenças estatisticamente significativas entre as diferentes condições (alimentação e jejum), tanto na ausência (bs) quanto na presença do estímulo com insulina (mx). Resultados apresentados como média \pm EPM (Al vs J p >0.05, [N=8]) 

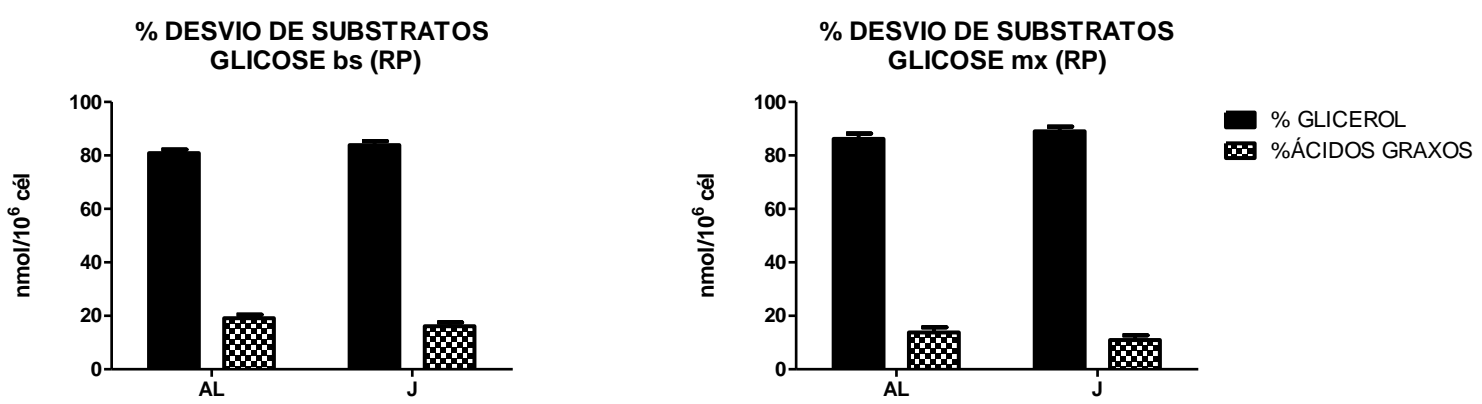

Figura 13A. Destino metabólico da glicose na lipogênese em gordura RP. Neste coxim adiposo, não observamos efeitos do jejum sobre o direcionamento do lactato, tanto na ausência (bs) quanto na presença de insulina $(\mathrm{mx})$. Resultados apresentados como média \pm EPM (Al vs $\mathrm{J} p>0.05[\mathrm{~N}=8]$ )
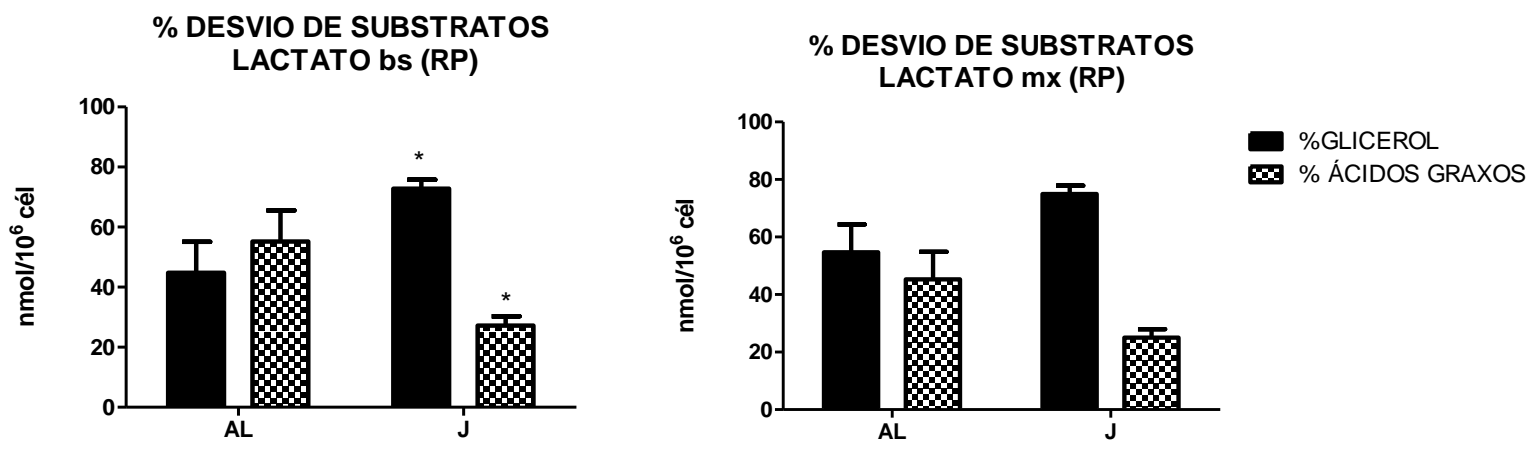

Figura 13B. Destino metabólico do ácido lático na lipogênese da gordura RP. Na situação basal (bs), constatamos que o jejum estimulou o direcionamento do ácido lático para a síntese de glicerol, esta diferença mostrou-se estatisticamente significativa. Resultados apresentados como média \pm EPM (Al vs $\left.\mathrm{J},{ }^{*} \mathrm{p}<0.05[\mathrm{~N}=8]\right)$. Na presença de insulina $(\mathrm{mx})$, o direcionamento do lactato a glicerol no animal Al foi aumentado e, por este motivo não observamos diferenças estatísticas entre os grupos (Al vs $\mathrm{J}, \mathrm{p}>0.05[\mathrm{~N}=8]$ ). 


\subsection{EXPRESSÃO DE PROTEÍNAS (WESTERN BLOTTING)}

Das Figuras 15 até 20 estão representadas as expressões proteicas envolvidas na lipogênese e gliceroneogênese do TAB dos tecidos SC e RP. As transferências das proteínas separadas nos géis foram feitas eletroforeticamente para membranas de nitro-celulose. As intensidades das bandas nas autoradiografias foram determinadas através de leituras por densitometria óptica das imagens fotografadas dos imunoblots (programa Image J). A proteína utilizada como normalizadora (housekeeping) foi a $\beta$-actina. 


\section{$\underline{5.10 .1 p A M P K \alpha}$}

A AMPK é uma proteína heterotrimétrica, que possui uma subunidade catalítica ( $\alpha$ ) e duas reguladoras $(\beta$ e y). Esta proteína exerce papel semelhante a de um sensor energético em inúmeros tecidos, incluindo o TA. Em casos de escassez de nutrientes, o aumento da concentração de AMP, e redução de ATP intracelular, induz a fosforilação da AMPK, ativando-a. Por conseguinte, pode ocorrer aumento da captação de glicose pelo adipócito e oxidação de lipídeos para a produção de ATP (Ceddia ., 2013; Long, Zierath., 2006). Através do Western Blotting, verificamos a expressão da subunidade catalítica em sua forma ativa. No entanto, não evidenciamos diferenças estatísticas relevantes entre os grupos estudados em ambos os tecidos SC e RP (Al vs J; p>0.05 [N=6]) (Figura 15)

\subsection{2 Ácido Graxo Sintase (FAS)}

A FAS é uma proteína citosólica, considerada um complexo multienzimático, responsável por catalisar o último passo da lipogênese, a conversão de Acetil-CoA e Malonil-CoA a ácidos graxos saturados, como o ácido palmítico, por exemplo. (Foufelle et al., 1996) Esta enzima parece ser ativada por carboidratos e AMPK. Em nosso estudo, não evidenciamos quaisquer alterações relacionadas às condições alimentares ( $\mathrm{J}$ ou $\mathrm{Al}$ ) dos animais tanto no tecido SC quanto no visceral RP. (Figura 16) 


\section{$\underline{\text { 5.10.3 Acetil CoA Carboxilase (ACC) }}$}

Esta proteína citosólica, atua no início da via lipogênica, pois é responsável pela conversão de Acetil-CoA a Malonil-CoA. Este último é um substrato indispensável para a síntese de ácidos graxos e, por este motivo, a ACC é considerada enzima passo limitante da lipogênese (Foufelle et al., 1996). Em nosso estudo, o jejum por $48 \mathrm{~h}$ reduziu a expressão desta proteína, tanto no tecido SC quanto no visceral $\mathrm{RP}\left(\mathrm{Al}>\mathrm{J},{ }^{*} \mathrm{p}<0.05[\mathrm{~N}=6]\right)$ (Figura 17)

\subsubsection{Fosfoenol Piruvato Carboxiquinase (PEPCK)}

Esta é uma proteína citosólica considerada chave da gliceroneogênese, que catalisa a reação de oxalacetato à fosfenolpiruvato, sendo este último indispensável pela a síntese de 1,3 bifosfoglicerato, gliceraldeído 3 fosfato, di-hidroxi-acetona fosfato e finalmente glicerol-3-fosfato (Nye., 2008)

O jejum por $48 \mathrm{~h}$ não alterou a expressão desta proteína, tanto no tecido SC quanto no tecido RP (Al vs J p >0.05, [N=6]). (Figura 18) 


\subsubsection{Lactato Desidrogenase (LDH)}

No tecido adiposo, esta enzima bidirecional catalisa a reação que converte piruvato a lactato ou a oxidação desta a piruvato. O lactato é captado da corrente sanguínea pelos adipócitos ou é produto da glicólise intracelular. Sob a ação da LDH, o lactato é convertido a piruvato e segue para a síntese de ácidos graxos ou glicerol-3-P (Brooks., 2009).

Nem o jejum e nem o estado alimentado interferiram com a expressão desta proteína em ambos os tecidos adiposos SC e RP (Figura 19).

\subsubsection{Transportador de Monocarboxilatos 1 (MCT1)}

Esta proteína de membrana é responsável pelo transporte de monocarboxilatos, como o lactato, por exemplo. No tecido adiposo, foram identificados quatro isoformas diferentes, sendo o MCT1 envolvido na captação do lactato para o interior do adipócito e liberação do mesmo substrato para o meio extracelular (Halestrap., 2012).

A sua expressão proteica do MCT1 não foi afetada pela condição alimentar em ambos os tecidos adiposos (Figura 20). 

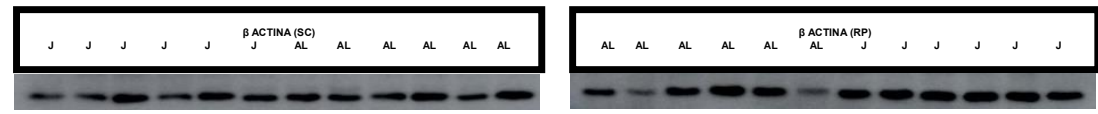

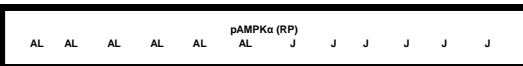

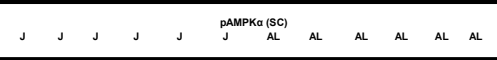

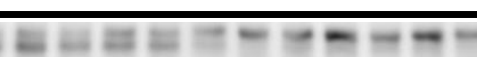

pAMPK $\alpha$ (SC)
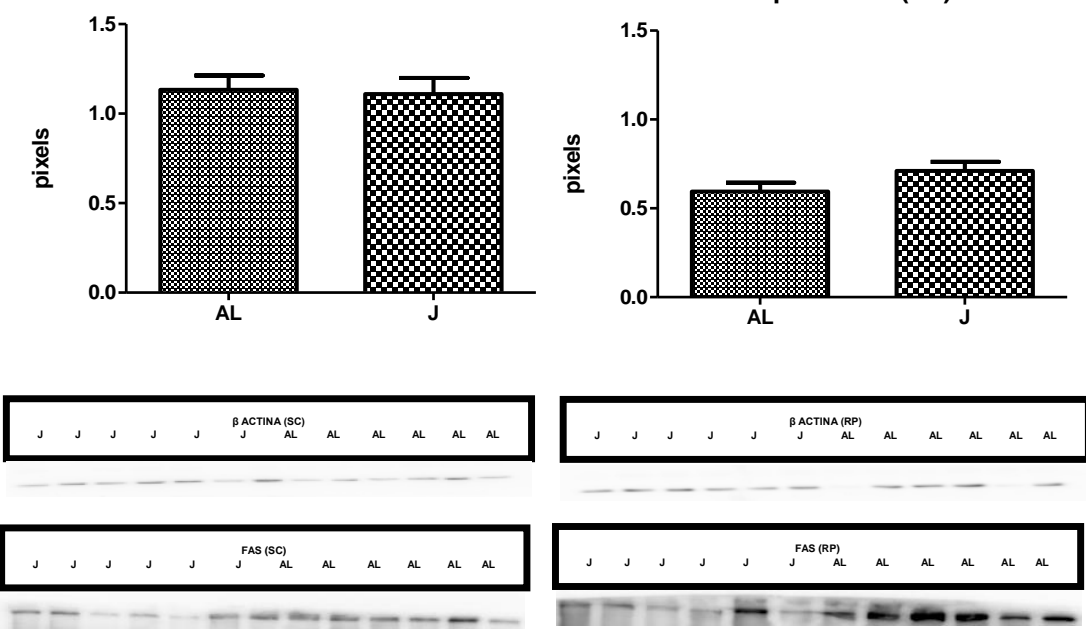

FAS (SC)
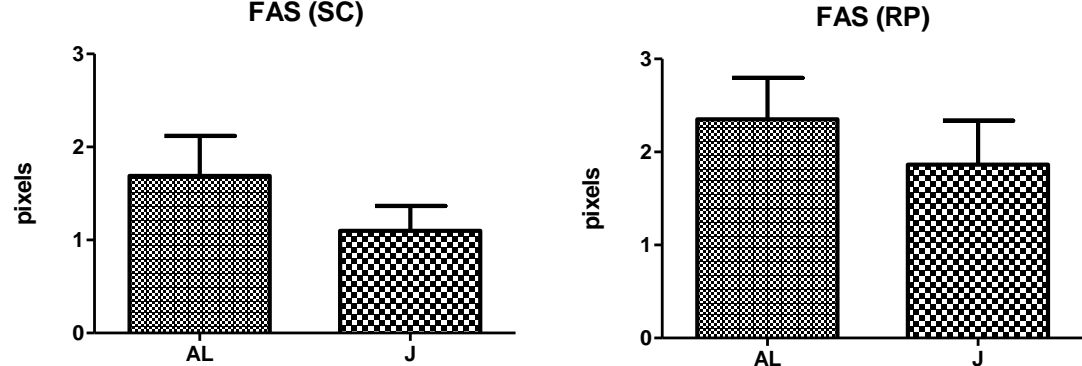

Figura 15 - Fotografias das bandas referentes

housekeeping $\beta$-actina e a proteína pAMPKa do tecido SC e RP. Não houve diferenças estatísticas entre os grupos (Al vs J; p>0.05 $[\mathrm{N}=6])$. À esquerda, representação gráfica da expressão proteica. Os dados representam a média \pm EPM (Al vs $\mathrm{J}, \mathrm{p}>$ $0.05[\mathrm{~N}=6])$

Figura 16 - Fotografias das bandas refrentes ao housekepping $\beta$-actina e da proteína FAS dos tecidos SC e RP. Não observamos diferenças entre os grupos (Al vs J; $\mathrm{p}>0.05 \quad[\mathrm{~N}=6])$. esquerda, representação gráfica da expressão proteica de ambos os tecidos. (Al vs J, p> 0.05 $[\mathrm{N}=6])$
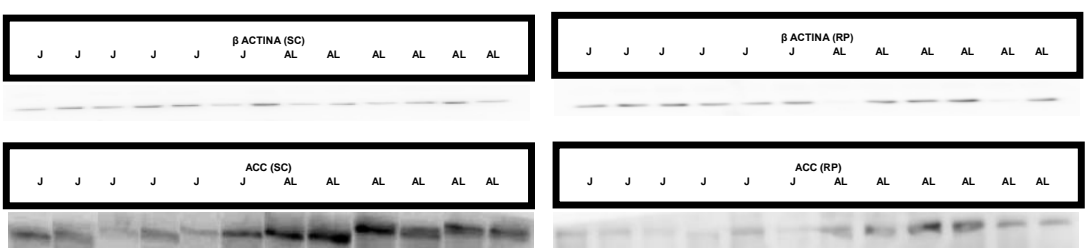

ACC (SC)

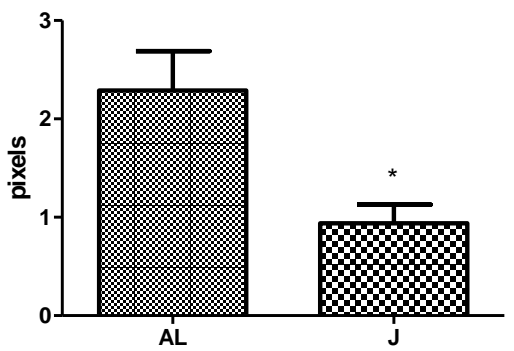

ACC (RP)

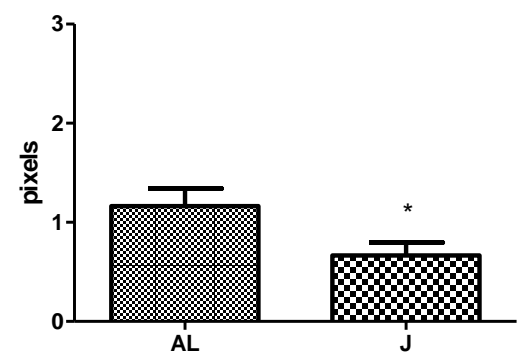

Figura 17 - Fotografias das bandas referentes

housekeeping $\beta$-actina e à proteína ACC dos tecidos SC e RP. Não evidenciamos diferenças estatísticas entre os grupos (Al vs J; p>0.05 [N=6]). À esquerda a express, o grupo $J$ mostrou menor expressão que o $\mathrm{Al}$ em ambos os tecidos. Os dados representam a média \pm EPM (Al vsJ, $\left.{ }^{*} \mathrm{p}<0.05[\mathrm{~N}=6]\right)$ 


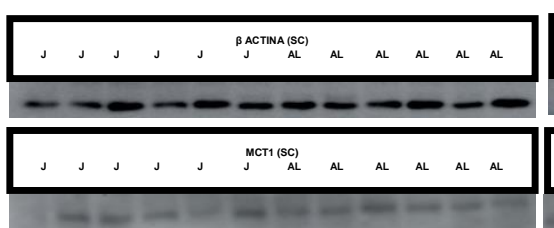

MCT 1 SC

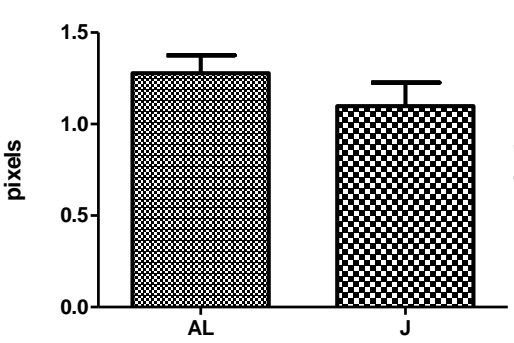

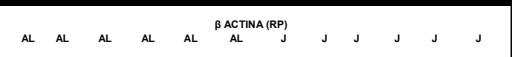

$--\infty-\infty-\infty$

AL AL AL AL AL ${ }_{\text {AL }}^{\text {MCt (RP) }}$ J J J J J J J J J

MCT1 RP

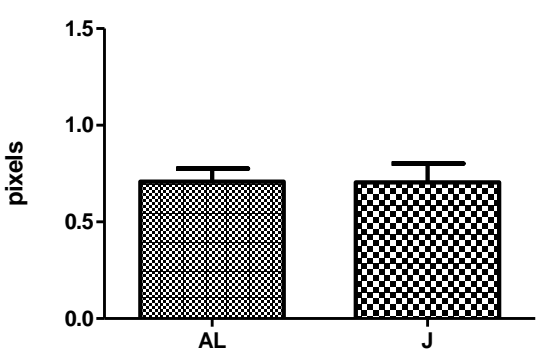

Figura 18 -

À esquerda, fotografias das housekeeping $\beta$-actina e a proteína MCT1 do tecido SC e RP. Não houve diferenças estatísticas entre os grupos (Al vs $\mathrm{J} ; \mathrm{p}>0.05$ $[N=6])$. bandas referentes ao
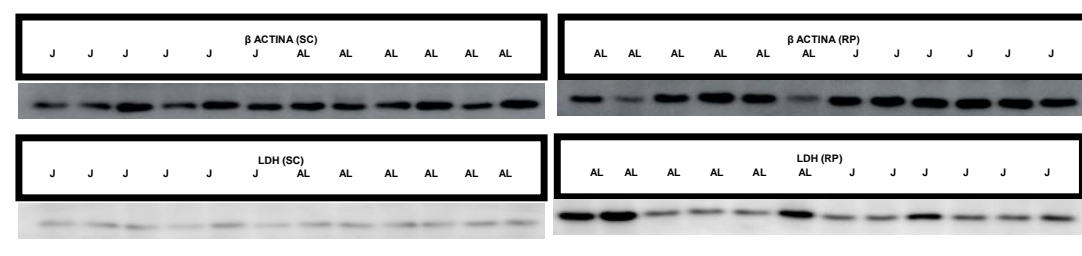

LDH SC
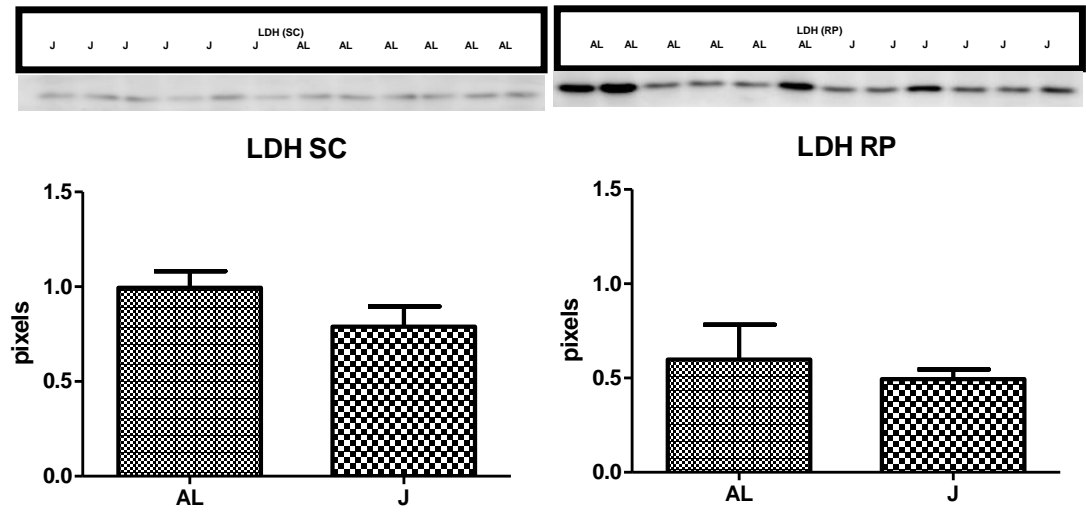

Figura 19 - Fotografias das bandas referentes housekeeping $\beta$-actina e a proteína LDH do tecido SC e RP. Não houve diferenças estatísticas entre os grupos (Al vs J; $\mathrm{p}>0.05 \quad[\mathrm{~N}=6]) . \quad \grave{\mathrm{A}}$ esquerda, representação gráfica da expressão proteica. Os dados representam a média \pm EPM (Al vs J, p> 0.05 $[\mathrm{N}=6])$

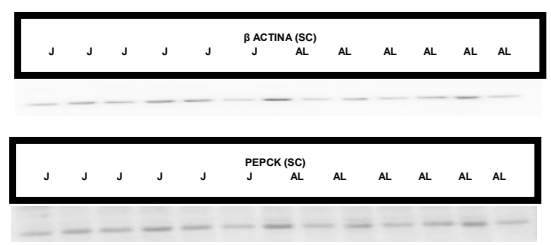

PEPCK SC

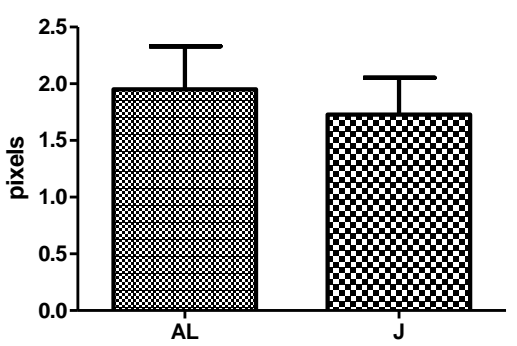

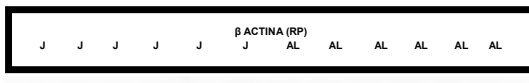

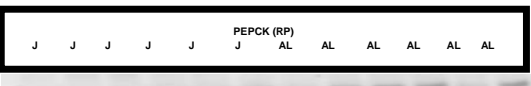

PEPCK RP
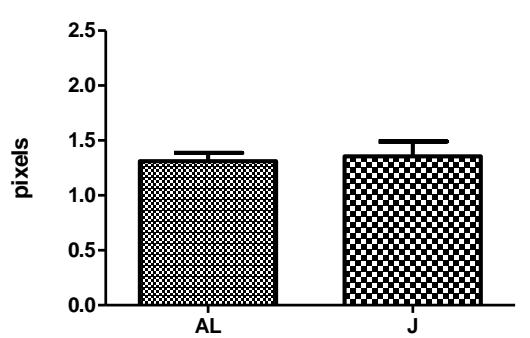

Figura 20 - Fotografias das bandas referentes ao housekeeping $\beta$-actina e a proteína PEPCK do tecido SC e RP. Não houve diferenças estatísticas entre os grupos (Al vs $\mathrm{J} ; \mathrm{p}>0.05$ $[\mathrm{N}=6])$. À esquerda representação gráfica da expressão proteica. Os dados representam a média \pm EPM (Al vs $\mathrm{J}, \mathrm{p}>$ $0.05[\mathrm{~N}=6])$ 


\subsection{CINÉTICA ENZIMÁTICA}

A cinética enzimática permite vislumbrar a velocidade de reação de uma proteína, quando em contato com seu substrato. A velocidade das reações pode ser alterada mediante tratamento experimental empregado aos animais. 


\subsubsection{ATP-Citrato Liase (ACL)}

A ACL é uma enzima citosólica que está intimamente ligada a lipogênese por que é responsável pela conversão de Citrato à Acetil CoA, sendo este último, indispensável para a síntese de ácidos graxos no TA (Kovacs et al., 2006; Leillott et al., 2004)

Nas análises estatísticas que foram normalizadas por $\mu \mathrm{g}$ de proteínas, não evidenciamos diferenças estatisticamente significativas entre os grupos em ambos os tecidos SC e RP (Al vs J, p>0.05 [N=6]).
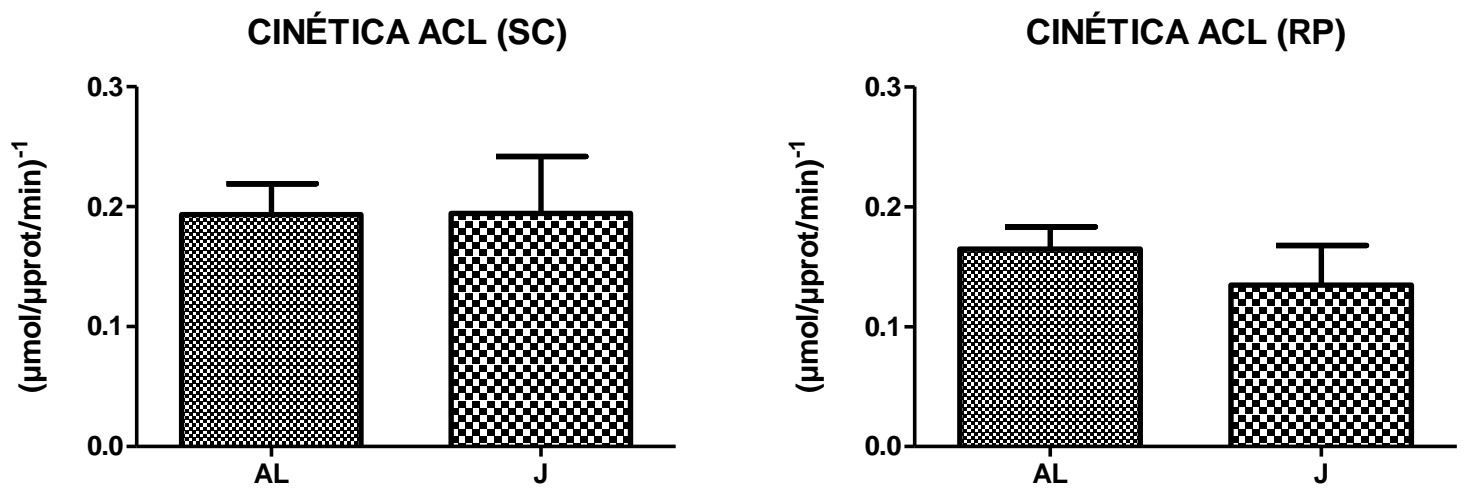

Figura 21 - Atividade da ATP Citrato Liase (ACL) do tecido SC e RP. Não observamos diferenças estatisticamente significativas entre os grupos (Al vs $\mathrm{J}, \mathrm{p}>0.05[\mathrm{~N}=6]$ ). 


\subsection{2 Ácido Graxo Sintase (FAS)}

Em nosso estudo, observamos que, no tecido SC, o Jejum levou ao aumento estatisticamente significativo da sua atividade $\left(\mathrm{Al}<\mathrm{J}\right.$; $\left.{ }^{*} \mathrm{p}<0.05[\mathrm{~N}=6]\right)$. No tecido RP, não observamos diferenças estatísticas entre os grupos estudados.
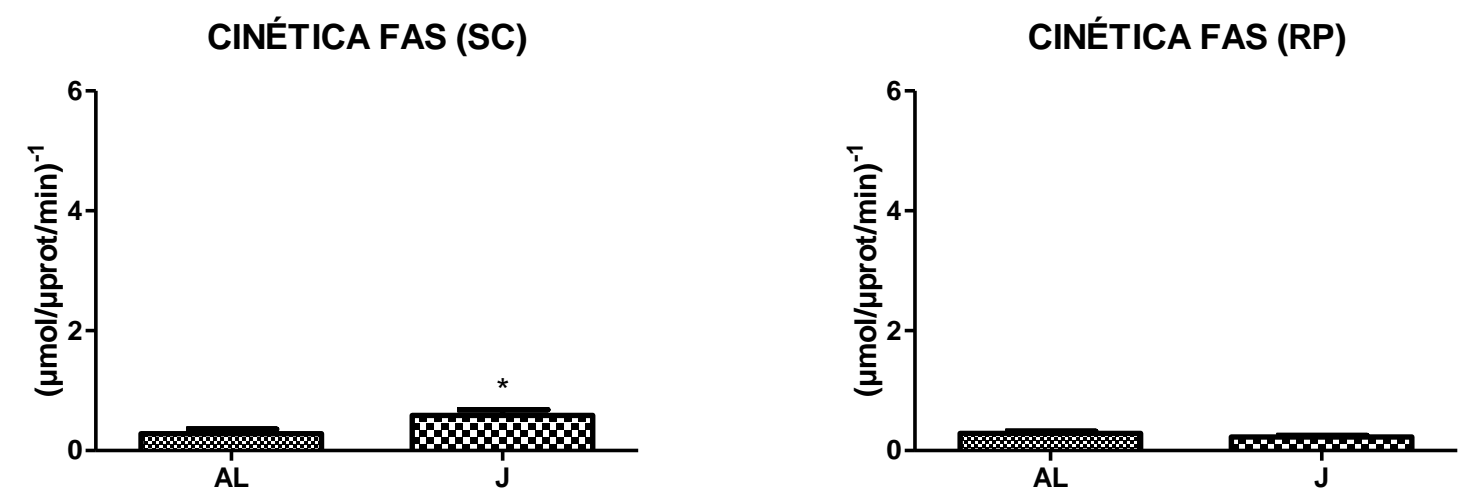

Figura 22 - Atividade da FAS. No tecido SC a FAS mostrou-se mais ativa na condição de jejum que o alimentado (Al vs $\mathrm{J},{ }^{*} \mathrm{p}<0.05 ; \mathrm{N}=6$ ). No tecido RP não observamos diferenças estatisticamente significativas entre os grupos (Al vs $\left.\mathrm{J},{ }^{*} \mathrm{p}<0.05[\mathrm{~N}=6]\right)$. 


\subsubsection{Lactato Desidrogenase (LDH)}

Observamos claramente que no tecido SC, o jejum induziu ao aumento estatisticamente significativo da atividade desta enzima $\left(\mathrm{Al}<\mathrm{J} ;{ }^{*} \mathrm{p}<0.05[\mathrm{~N}=10]\right)$. Já no tecido RP, não se evidenciou diferenças entre os grupos estudados $(\mathrm{Al}=\mathrm{J}$; $p>0.05[N=10])$.
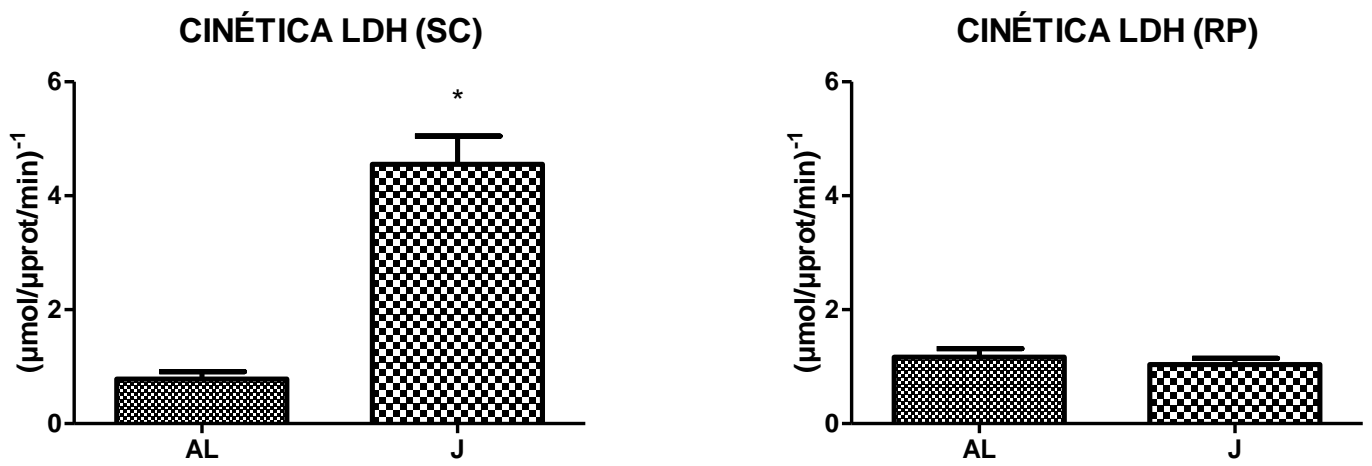

Figura 23 - Atividade da LDH. No tecido SC, o grupo jejum apresentou maior atividade enzimática quando comparado ao grupo de animais alimentados. (Al vs $\mathrm{J},{ }^{*} \mathrm{p}<0.05[\mathrm{~N}=6]$ ). No entanto, não observamos o mesmo panorama na gordura RP. 


\section{$\underline{5.11 .4 \text { Glicose-6-fosfato desidrogenase (G6PDH) }}$}

A Glicose-6-P desidrogenase é uma enzima catalisadora do primeiro passo da via das pentoses-fosfato, via alternativa de oxidação da glicose-6-P formada através da glicólise. Nesta reação, ocorre produção de ribose-5-P, $\mathrm{CO}_{2}$ e NADPH. Deste modo, a atividade máxima desta enzima é determinada pelo incremento da absorbância através da formação NADPH que é um cofator importante para a síntese de ácidos graxos.

A atividade desta enzima mostrou-se reduzida na condição de jejum somente do coxim adiposo RP (Al vs J, * $\mathrm{p}<0.05[\mathrm{~N}=6])$ (Figura 24).

CINÉTICA G6PDH (SC)

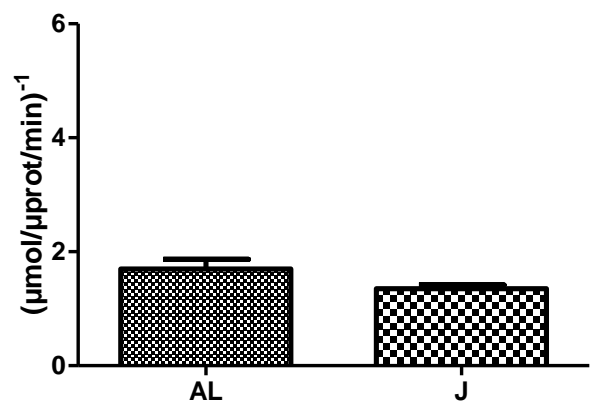

CINÉTICA G6PDH (RP)

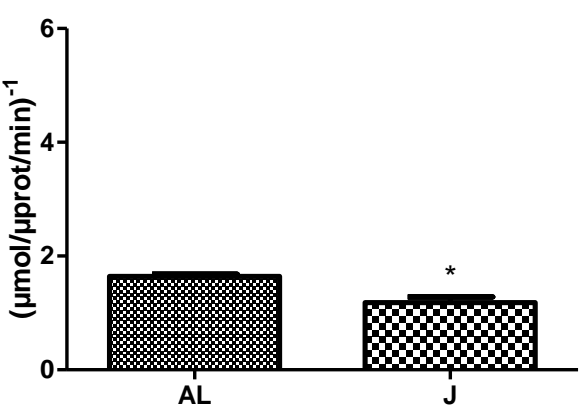

Figura 24 - Atividade da G6PDH. A atividade máxima desta enzima em animais em jejum apresentou-se reduzida em comparação com a de animais alimentados somente no coxim adiposo RP (Al vs $\left.\mathrm{J},{ }^{\star} \mathrm{p}<0.05[\mathrm{~N}=6]\right)$ 


\section{$\underline{5.11 .5 \text { Málica }}$}

A enzima Málica atua no ciclo Piruvato-Malato, convertendo Malato a Piruvato. Na lipogênese, o piruvato pode servir de substrato tanto para a síntese de ácidos graxos, quanto para a síntese de glicerol-3-P (gliceroneogênese). O jejum por 48 hs não modificou a velocidade de reação da enzima, se comparado ao grupo Alimentado (Figura 25).

CINÉTICA MÁLICA (SC)

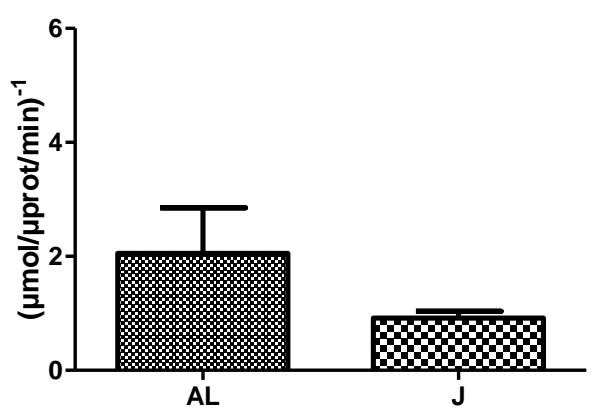

CINÉTICA MÁLICA (RP)

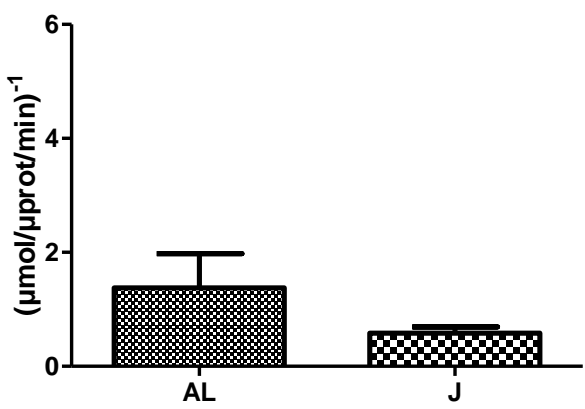

Figura 25 - Atividade da Málica. Não houve diferenças estatísticas na atividade da enzima Málica nas situações estudadas em ambos os coxins adiposos (Al vs $\mathrm{J}, \mathrm{p}>0.05[\mathrm{~N}=6]$ ) 


\subsection{LACTATO TECIDUAL}

Diante dos resultados encontrados com relação a utilização do lactato para a lipogênese e dos resultados obtidos na cinética enzimática da LDH, julgamos conveniente verificar se a condição de jejum levaria a alterações nos níveis de lactato nos coxins adiposos que poderiam contribuir para tais resultados. No tecido $\mathrm{RP}$, na condição de jejum, observamos maior conteúdo de lactato tecidual (Al >J; $\left.{ }^{*} \mathrm{p}<0.05[\mathrm{~N}=6]\right)$.

LACTATO TECIDUAL (SC)

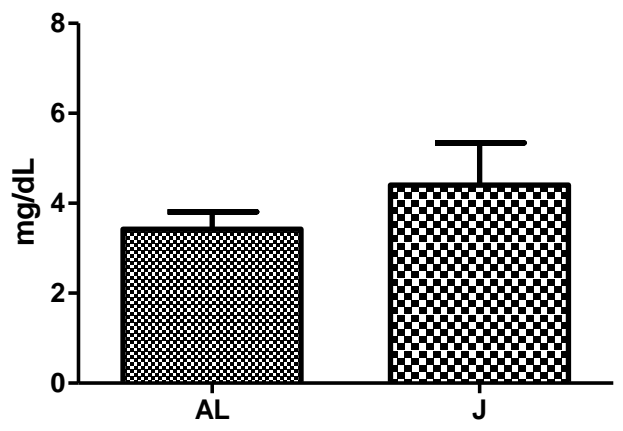

LACTATO TECIDUAL (RP)

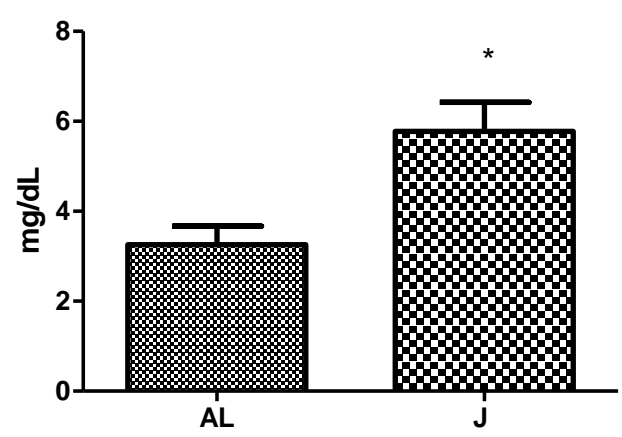

Figura 26 - Lactato Tecidual. O conteúdo de lactato no coxim adiposo RP mostrou-se maior em animais jejuados que alimentados. Resultados apresentados como média \pm EPM (Al vs $\mathrm{J},{ }^{*} \mathrm{p}<0.05[\mathrm{~N}=6]$ ). Não observamos diferenças significativas no tecido SC. 


\section{DISCUSSÃo}

O tecido adiposo branco atua, entre outras funções, no balanço energético do organismo, mobilizando AG contidos no interior do adipócito em momentos de escassez de nutrientes, para atender as necessidades energéticas de tecidos periféricos e, no período pós-prandial, por exemplo, prioriza o armazenamento de energia em forma de TAG. Para esta síntese ocorrer no adipócito, a geração de glicerol-3-P é indispensável. Neste ponto, a glicose é considerada substrato preferencial para a síntese de glicerol-3-P (Muñoz et al., 2010). Além deste substrato, outros como piruvato, alanina e lactato também são utilizados para a síntese de glicerol-3-P, e a via metabólica é denominada de gliceroneogênese. A literatura postula que esta é ativada em situações de escassez de nutrientes, como no jejum, além de ser inibida pela presença de glicose e insulina (Ballard et al., 1966; Brito et al, 200; Meyhunas et al., 1976). No entanto, esta via foi quase que exclusivamente estudada utilizando o piruvato como substrato ao invés do lactato. Este último é um produto da glicólise anaeróbia realizada em diversos tecidos e é continuamente lançado na corrente sanguínea, principalmente no período pósprandial, em que há oferta de nutrientes e carboidratos. O excesso de ácido lático no sangue poderia levar a um desequilíbrio no sistema de tamponamento ácido-básico e, talvez também por este motivo, o organismo o remova tão rapidamente. Diante disso, nossa hipótese é a de que a gliceroneogênese possa ser regulada de acordo com o substrato em questão. No período pós-prandial, com o aumento da produção de lactato em diversos tecidos e no próprio adipócito, o TA atuaria como uma via de escape deste substrato, utilizando-o para a síntese de glicerol-3-P através da gliceroneogênese. 
Nosso estudo teve como objetivo avaliar a lipogênese e a contribuição da gliceroneogênese em condições alimentares bastante distintas como no jejum prolongado (de $48 \mathrm{~h}$ ) e o estado alimentado.

Para a caracterização do estado de jejum prolongado alguns critérios foram considerados:

- Redução da glicemia. Ainda que esta esteja em níveis normais (não hipoglicêmicos) graças a gliconeogênese hepática, mas reduzida em comparação ao período pós-prandial;

- Redução da insulinemia. Zanquetta (2006), estudando ratos em jejum, verificaram que a cessação de ingestão alimentar reduzia drasticamente a secreção de insulina pelas ilhotas pancreáticas, enquanto que o estado alimentado, em razão do maior aporte de nutrientes, particularmente carboidratos e alguns aminoácidos estimulavam sua secreção.

- Redução da leptinemia. A leptina é uma adipocina intimamente ligada à manutenção da massa de gordura corporal, capaz de modular o consumo e o gasto de energia do organismo, desempenha papel fundamental na regulação das reservas de lipídeos do TA e, deste modo, do volume celular do adipócito. A leptina é reduzida no jejum, situação que leva ao aumento do apetite e redução da termogênese, e sua síntese e secreção parece ser estimulada na presença de alimentos e por insulina, levando a redução do apetite e aumento do gasto energético do organismo (Donato et al., 2006; Korbonits et al., 2007). Em nosso trabalho, evidenciamos diferenças significativas entre os estados alimentares, em que o jejum resultou em menores níveis séricos. 
- Aumento de corpos cetônicos. Corpos cetônicos, como o $\beta$ hidroxibutirato, são produtos oriundos da cetogênese hepática em consequência de intensa lipólise, fenômeno geralmente intensificado durante o jejum. Na lipólise, a oxidação dos ácidos graxos gera, além de $\mathrm{NADH}^{+}$e $\mathrm{FADH}_{2}$, o Acetil-CoA, sendo este o principal substrato para a síntese de corpos cetônicos. (Akran.,2013)

De acordo com o esperado, nossas análises bioquímicas evidenciaram as características próprias do jejum no grupo experimental. Além destas análises, devido a escassez de dados na literatura a respeito deste assunto, julgamos de interesse mensurar o conteúdo de lactato sanguíneo, isso porque, o jejum poderia provocar alterações e, desta maneira, influenciar os resultados obtidos nos ensaios biológicos nos quais os adipócitos dos diferentes tecidos e animais foram submetidos. Os resultados mostraram que, nas nossas condições experimentais, não houveram alterações importantes na lactacidemia, não sendo, portanto, um parâmetro para a avaliação do estado de jejum.

Em estudos anteriores realizados em nosso laboratório, constatamos que os coxins adiposos de diferentes regiões, como a inguinal subcutânea, o tecido visceral periepididimal ou o visceral retroperitoneal, possuem morfologia e metabolismo distintos (Castro NC., 2010). Constatamos que, no tecido SC, predominam adipócitos menores, mais sensíveis à insulina, se comparados aos da região RP, que possui adipócitos de maior volume, com maior capacidade basal de captação de glicose e de incorporação de glicose em lipídeos, embora tenhamos constatado menor expressão da proteína FAS. Assim, naquele estudo, concluímos que os diferentes territórios adiposos possuem capacidades metabólicas distintas que impactam de forma importante sobre o controle fisiológico do organismo. 
No presente estudo, após o isolamento dos adipócitos, observamos que no tecido SC, o jejum promoveu significativa redução do volume celular acompanhando a redução do peso dos coxins SC inguinal de ambos os lados (direito e esquerdo), sugerindo intensa atividade lipolítica ao lado de reduzida atividade lipogênica, mostrando-se um tecido ágil para atender às necessidades energéticas de tecidos periféricos. Em contraste, ao analisar os coxins e adipócitos da região RP, não observamos o mesmo resultado, isto é, não houve redução de volume celular ou da massa dos coxins adiposos. De acordo com Jensen (1997) o tecido visceral mostrase mais lipolítico, talvez, devido ao maior volume dos seus adipócitos, ou seja, quanto maior o adipócito, maior a capacidade lipolítica, comparada a dos adipócitos subcutâneos. No entanto, a medida da lipólise não permite avaliar o grau de reesterificação dos ácidos graxos pois, como mostraram Jensen et al (2001), a reesterificação dos $A G$ é um processo que ocorre naturalmente, em roedores e em humanos, e equivale a aproximadamente $60 \%$ dos lipídeos totais hidrolisados durante a lipólise. Os resultados evidenciados com a manutenção do coxim adiposo e do volume do adipócito RP sugerem que a atividade lipolítica tenha sido contrabalançada por acentuada atividade de re-esterificação de AG servindo como um mecanismo protetor, frente a esta situação de estresse. Com relação ao volume celular dos diferentes coxins, constatamos que adipócitos RP se mantiveram maiores que os SC, mesmo após $48 \mathrm{~h}$ de jejum. Os adipócitos SC, adicionalmente, apresentaram uma redução de cerca de $35 \%$ em seu volume, ao passo que, no caso dos RP, a redução foi de $15 \%$ e não foi significativa.

A respeito dos possíveis inibidores ou potencializadores da utilização do lactato para a lipogênese e gliceroneogênese, encontramos dados divergentes na literatura. Para Nye et al., (2008) que avaliaram a gliceroneogênese in vivo, 
utilizando água tritiada $\left({ }^{3} \mathrm{H}_{2} \mathrm{O}\right)$ como marcador, a oferta de glicose concomitantemente com o lactato, aumentou intensamente a utilização do lactato para a síntese de glicerol de triglicérides. Enquanto isso, outros trabalhos postulam que (Frasson et al., 2012; Reshef et al., 2003), a glicose e a insulina atuam como potentes inibidores desta via. Além de o jejum ser o principal estímulo para a síntese de glicerol de triglicérides no TA, a insulina inibe a atividade da PEPCK, enzima chave da síntese de glicerol-3-P. Diante destas controvérsias, realizamos primeiramente determinações da lipogênese a partir do lactato em adipócitos isolados, somente de animais alimentados. Nos ensaios, as células adiposas foram incubadas frente a diferentes concentrações de glicose $(0 \mathrm{mM}, 1 \mathrm{mM}$ e $5 \mathrm{mM})$, em presença $(10 \mathrm{nM})$ ou ausência $(0 \mathrm{nM})$ de insulina. As respostas obtidas demonstram claramente, que a presença de glicose no meio, seja na concentração $1 \mathrm{mM}$ ou $5 \mathrm{mM}$, é uma importante potencializadora da capacidade de incorporação de lactato em lipídeos totais, em AG e também em glicerol de TAG. Apesar de ainda não ser possível determinar de forma mais específica o papel da glicose neste processo, entendemos que a sua presença no tubo de ensaio realça a resposta dos adipócitos de modo que passamos a enriquecer com glicose o meio de incubação dos testes biológicos realizados para investigar a participação do lactato na gliceroneogênese in vitro. Além disso, a presença de insulina $(10 \mathrm{nM}$, concentração capaz de produzir uma resposta máxima no adipócito, mas muito acima da que ocorre em condições fisiológicas), aumentou significativamente a resposta lipogênica e gliceroneogênese, principalmente com a presença da glicose (1 mM ou $4 \mathrm{mM}$ ).

Sabe-se que a lipogênese responde a fatores nutricionais e hormonais e que a presença de nutrientes, principalmente os carboidratos, estimulam a maquinaria necessária para promovê-la. De acordo com Czech (2013), esta maquinaria é 
ativada pela insulina secretada que, por sua vez, pode promover, além do aumento da captação de glicose, aumento de sinalizações necessárias para a síntese e atividade de proteínas envolvidas na lipogênese. No teste de incorporação de glicose em lipídios totais, no tecido SC, tanto na situação basal (não estimulada por insulina) quanto em presença de insulina $(10 \mathrm{nM})$, os animais alimentados apresentaram maior capacidade lipogênica que os animais submetidos ao jejum; em contraste, no tecido RP, na ausência de insulina, o jejum não alterou a capacidade celular em realizar lipogênese. Em outras palavras, no estado alimentado observouse maior capacidade de incorporação da hexose porque, nesta condição, os adipócitos isolados da gordura SC submetidos ao teste biológico de determinação da lipogênese ainda preservam ativos os mecanismos celulares da via lipogênica e, deste modo, a incorporação de glicose e lactato em lipídeos está favorecida mesmo na ausência de insulina. Os adipócitos provenientes do tecido RP apresentaram diferenças em relação aos SC na utilização de glicose para a lipogênese. Em condições basais, mostraram maior capacidade lipogênica, tanto em adipócitos provenientes de animais alimentados como de animais em jejum prolongado. A resposta ao estímulo insulínico foi reduzida na condição de jejum.

Na síntese de lipídeos, algumas enzimas possuem papel chave, como a enzima ácido graxo sintase (FAS), uma proteína citosólica considerada um complexo multienzimático, responsável por catalisar o último passo da lipogênese, a conversão de Acetil-CoA e Malonil-CoA até ácidos graxos saturados, como o ácido palmítico, por exemplo. Apesar de esta enzima ser ativada por carboidratos e insulina, não encontramos diferenças significativas entre os grupos estudados na sua expressão, avaliada por Western Blotting. No entanto, quando avaliada através da cinética enzimática, observamos que no jejum, sua atividade encontra-se 
aumentada no tecido SC. Provavelmente, este resultado obtido deva-se a redução de lipídios causada pelo jejum, que resultou em uma maior concentração de proteínas das amostras estudadas. Talvez, a redução da síntese de lipídeos totais deva-se à redução da atividade de enzimas-chave envolvidas em etapas anteriores a esta, como sua proteína reguladora, a AMPK, que de acordo Long, Zierath (2006), pode estimular a expressão da enzima FAS.

A AMPK é considerada um sensor energético do adipócito. Em casos de escassez de nutrientes, como no jejum, por exemplo, ocorre redução do conteúdo intracelular de ATP e aumento da concentração de AMP, o que induz a fosforilação da AMPK, ativando-a. O resultado desta ativação é o aumento da oxidação de lipídeos para a geração de ATP. Ao quantificar a expressão da AMPK em sua forma ativa, a pAMPKa, não evidenciamos diferenças significativas entre os grupos Al ou J em ambos os tecidos SC e RP.

Mediante a determinação do ritmo de Incorporação de Glicose (ou Lactato) no resíduo AG de triglicerídeos, investigamos o processo denominado lipogênese de novo (DNL) que consiste na síntese de AG a partir de substratos não lipídicos. Em nosso estudo, comprovamos uma vez mais que os dois territórios adiposos que foram foco deste trabalho metabolizaram de forma diferente os mesmos substratos. No tecido SC, na ausência de insulina, os adipócitos isolados de ratos em jejum não apresentaram qualquer alteração na síntese de ácidos graxos a partir de glicose quando comparados aos de animais alimentados. O estímulo destas células com insulina resultou em aumento significativo da síntese de AG nos animais do grupo Al. No tecido RP, adipócitos de animais em jejum mostraram queda no ritmo de incorporação de glicose em AG tanto na situação basal quanto apos estimulação por insulina. Quando o substrato foi o lactato, tanto no tecido SC quanto no RP, o jejum 
reduziu a DNL tanto na presença quanto na ausência de insulina, mostrando novamente que o jejum é um forte indutor de resistência à insulina. A mais intensa atividade lipolítica decorrente do jejum é apontada como uma situação capaz de levar a resistência à insulina no adipócito, prejudicando a captação de glicose pelos transportadores GLUT4. Como consequência, pode ocorrer redução dos estímulos nas vias de sinalização intracelular, na expressão gênica e na síntese de proteínas relacionadas com a lipogênese (Zanquetta et al., 2006). Sendo assim, não só a captação de glicose, mas também as vias metabólicas da lipogênese subsequentes podem ter sido prejudicadas.

$\mathrm{Na}$ etapa em que o citrato é convertido a piruvato no citosol, este substrato pode ser direcionado para a síntese de ácidos graxos. Para verificar se houve alterações nesta etapa, realizamos o teste de cinética enzimática da proteína ATP citrato liase, que catalisa exatamente a conversão de citrato a piruvato. Esta enzima também é considerada chave na DNL, no entanto, não evidenciamos diferenças estatísticas entre os grupos nos tecidos SC e RP.

Ainda sobre a DNL, mas um pouco mais adiante na via de síntese de AG, a enzima Acetil-CoA Carboxilase $(A C C)$ é responsável pela conversão de Acetil-CoA a Malonil-CoA. Estes dois são substratos indispensáveis para a síntese de ácidos graxos. Por este motivo, a ACC é também considerada passo limitante da lipogênese. Em nosso estudo, a sua expressão avaliada por Western Blotting, foi reduzida no jejum por $48 \mathrm{~h}$, tanto no tecido SC quanto no visceral $\mathrm{RP}$ e, sendo assim, a sua redução pode ter contribuído para a diminuição da lipogênese de novo avaliada anteriormente nos ensaios biológicos com adipócitos isolados.

A geração de glicerol-3-P é importante para a síntese de TAG. Ácidos graxos captados pelo adipócito ou sintetizados em seu citoplasma precisam ser 
esterificados ao glicerol-3-P (Kalhan., 2001). Assim, a incorporação de D-[U- $\left.{ }^{14} C\right]-$ Glicose ou ${ }^{14} \mathrm{C}$-Ácido Lático no resíduo glicerol dos TAG também foi avaliada neste estudo. Para obter os dados referentes à Incorporação de D-[U- $\left.{ }^{14} \mathrm{C}\right]-G$ licose e Lactato em Glicerol de Triglicérides calculamos a diferença entre a Incorporação de em Lipídios e de D-[U- $\left.{ }^{14} \mathrm{C}\right]$-Glicose ou ${ }^{14} \mathrm{C}$-Ácido Lático em Ácidos Graxos. A partir daí, obtivemos o grau de incorporação de D-[U- $\left.{ }^{14} \mathrm{C}\right]$-Glicose no resíduo Glicerol de Triglicérides. Para a síntese de glicerol-3-P, o TAB pode realizar a fosforilação direta do glicerol pela gliceroquinase (GyK), entretanto, esta enzima é de conteúdo e atividade muito reduzidas no TA branco se comparada a do TA marrom e do fígado (Beale, 2002; Chaves, 2006) ou pode ser gerado através da gliceroneogênese, que é a via metabólica que realiza a síntese de novo de glicerol a partir de substratos intermediários não glicídicos como lactato, piruvato e alanina. Esta via será discutida mais adiante. Além disso, a glicose é apontada como a maior fonte geradora de glicerol-3-P. Isto se dá pela conversão de di-hidroxi-acetona-P à glicerol-3-P, que é catalisada pela enzima glicerol-3-P desidrogenase.

Nos adipócitos isolados das gorduras SC e RP, nos quais se determinou a capacidade basal de incorporar glicose em glicerol de TG, não encontramos diferenças significativas nesta resposta entre animais alimentados ou em jejum por $48 \mathrm{~h}$, mas após estimulação máxima com insulina, apesar de ambos os grupos terem apresentado aumento da incorporação em glicerol, a resposta dos animais alimentados superou a dos jejuados. Aqui, a insulina pareceu exercer papel potencializador da síntese de glicerol-3-P a partir de glicose. Desta vez, não observamos diferenças metabólicas relevantes entre as diferentes regiões adiposas dos animais. Com relação ao direcionamento dos substratos glicose e lactato para a síntese de AG ou glicerol, os tecidos SC e RP mostraram comportamentos 
semelhantes embora a proporcionalidade em números absolutos tenha se mostrado diferente. No jejum, somente no tecido RP, a insulina promoveu direcionamento mais intenso do lactato para a síntese de glicerol-3-P (cerca de $75 \%$ do lactato foi incorporado em glicerol contra $55 \%$ em animais alimentados). Isto mostra que apesar do tecido RP possuir adipócitos de maior volume e, por isso, ser considerado um adipócito com tendência a desenvolver resistência à insulina, esta via metabólica responde melhor a insulina do que o tecido SC. Neste último, a resposta de incorporação de lactato em glicerol de TAG é um processo metabólico praticamente não responsivo à insulina.

Como citado anteriormente, a gliceroneogênese é a via metabólica que realiza síntese de novo de glicerol a partir de substratos intermediários não glicídicos como lactato, piruvato e alanina. (Hanson., 2003; Jomain., 1969). Com relação ao lactato, esta via envolve a sua oxidação a piruvato catalisada pela enzima lactato desidrogenase seguida pela geração de oxalacetato, pela piruvato carboxilase e, na sequência, pela descarboxilação do oxaloacetato para formar fosfo-enol-piruvato. Esta última reação é passo limitante da via de síntese de glicerol-3-P e a enzima envolvida é a fosfo-enol-piruvato carboxiquinase citosólica. (PEPCK-C) (Nye C et al., 2008). Quando utilizamos o lactato como substrato no teste de incorporação de lactato em glicerol, em que é possível quantificar a gliceroneogênese, observamos diferenças significativas em ambos os tecidos tanto na ausência quanto na presença de insulina. A menor resposta à insulina verificada em animais em jejum não pode ser atribuída a uma resistência ao hormônio porque a magnitude desta resposta basal foi similar em animais alimentados e em jejum, isto é, em ambos os casos, a insulina promoveu um aumento da ordem de $50 \%$ em relação à respectiva resposta basal. Além disso, estes testes mostraram claramente que, ao contrário do que a 
literatura já postulou sobre o jejum como estímulo para a gliceroneogênese e a insulina como inibidora da atividade da enzima passo limitante desta via (PEPCK), a incorporação do lactato no resíduo glicerol de triglicérides não foi estimulada pelo jejum e, tão pouco, inibida pela insulina. Para tentar esclarecer este fenômeno, avaliamos posteriormente a expressão da enzima chave da gliceroneogênese, a PEPCK.

A PEPCK-C, como dito anteriormente, parece ser estimulada pelo jejum ou em dietas desprovidas de carboidratos e inibida na presença de insulina. Um estudo com animais geneticamente modificados evidenciou que a depleção de PEPCK resulta em redução da gordura corporal e aumento da atividade lipolítica (Olswang et al., 2002). Ao contrário, o aumento da PEPCK intensifica a gliceroneogênese. (Franckhauser et al., 2002). Para Frasson D (2012), a regulação desta enzima é fundamental no controle da gliceroneogênese. Diante destes dados, verificamos como se encontraria a expressão desta enzima por Wester Blotting, para corroborar com os dados obtidos da gliceroneogênese, não encontramos diferenças entre os ratos alimentados e os submetidos ao jejum por 48 h. Nye et al. (2008), utilizaram em seu estudo, traçadores radioativos ([U- ${ }^{14} \mathrm{C}$-glicose; $\left.{ }^{3} \mathrm{H}_{2} \mathrm{O}\right)$ para avaliar a gliceroneogênese in vivo, em ratos submetidos ao jejum e em ratos alimentados com dieta rica em glicose, além de estudar a atividade da PEPCK nos tecidos SC e periepididimal (PE). Como resultado, reportaram que a gliceroneogênese era mais ativa nos animais alimentados com dieta rica em glicose quando comparado com os mantidos em jejum. Ao mesmo tempo, encontraram maior atividade da PEPCK-C no grupo submetido ao jejum de $48 \mathrm{~h}$ que nos alimentados com dieta rica em carboidratos. Diante disso, parece que a geração de glicerol-3-P não pode ser avaliada somente através de ensaios moleculares. 
Para que o lactato seja utilizado para a gliceroneogênese, o processo de captação do meio extracelular e o transporte para o intracelular se fazem através de transportadores específicos MCTs (transportadores de ácidos monocarboxílicos), como o MCT1, por exemplo, ou a partir da glicólise anaeróbia, sendo o lactato produto desta via metabólica dentro do adipócito. Julgamos de interesse verificar se a redução da síntese de glicerol a partir de lactato nos animais jejuados foi resultado de prejuízos na captação deste substrato para o interior da célula. Para isso, desenvolvemos o teste de captação de lactato. Neste teste, primeiramente verificamos o efeito da presença da glicose $(4 \mathrm{mM})$ e da insulina (10 nM) nos tubos de ensaio. Observamos que na ausência de glicose $(0 \mathrm{mM})$ a captação de ambos os grupos e tecidos não se diferenciam, entretanto, observamos um aumento drástico da captação do substrato em presença da glicose e, além disso, observamos diferenças entre os tecidos adiposos. No tecido adiposo SC, por exemplo, a captação de lactato na ausência de insulina em animais alimentados é aproximadamente 4 vezes maior que a de animais jejuados, frente ao estímulo máximo com insulina, e um aumento de quase $100 \%$ desta medida se comparado às condições basais. Entretanto, nos animais em jejum, verificamos que a captação de lactato ficou praticamente inalterada na presença de insulina, este dado é mais uma indicação de que o jejum promoveu certo grau de resistência a insulina no adipócito.

Com relação ao tecido RP, na situação basal, nos animais em jejum ocorreu menor capacidade de captação de lactato, enquanto que, frente ao estímulo com insulina, não observou-se diferença significativa entre as diferentes condições estudadas. Para Newby FD et al (1998), o jejum pode promover aumento em até $30 \%$ da produção de lactato a partir da glicose e, além disso, este fenômeno relacionou-se positivamente com o volume celular do adipócito. Desta maneira, o 
aumento da concentração intracelular do lactato poderia ser um fator limitante para a captação deste substrato para o interior da célula e poderia justificar o por quê do jejum ter diminuído a captação de lactato em relação ao grupo Al. Para verificar a validade desta hipótese, quantificamos os níveis de lactato nos homogenatos de tecido, e observamos que, no tecido RP, a concentração de lactato nos animais submetidos ao jejum foi maior que nos alimentados, embora não tenhamos observado o mesmo panorama no tecido SC. Talvez, a produção de lactato intracelular tenha relação com a sensibilidade a insulina, isso porque, neste teste de captação de lactato, no tecido visceral RP, não observamos diferenças relacionadas à sensibilidade à insulina, diferentemente do ocorrido na gordura SC.

O estudo da captação de lactato pode relacionar-se diretamente com a expressão de seus transportadores (MCTs). Assim, diante dos resultados supracitados, poderíamos inferir que as diferenças encontradas estão intimamente ligadas com a sensibilidade à insulina e que esta, estaria ligada aos transportadores de monocarboxilatos. De acordo com Lovejoy (1992), que estudaram parâmetros sanguíneos de lactato, glicose e insulina em indivíduos obesos saudáveis, mostrou que, em situações onde há resistência à insulina, observa-se aumento dos níveis sanguíneos de lactato. Além disso, Hajduch et al (2000) estudaram em ratos diabéticos, a captação de lactato e a expressão de proteínas MCT1 em adipócitos da região periepididimal. Os autores evidenciaram que o estado diabético reduziu a expressão de MCT1 avaliada por Western Blotting. Em nosso estudo, pela análise das medidas do lactato sanguíneo, como dito anteriormente, não encontramos diferenças entre as condições experimentais e, sendo assim, esta não seria uma possibilidade para as diferenças encontradas na captação de ácido lático. Além disso, pelo estudo da expressão de MCT1 por Western Blotting, também não 
observamos diferenças significativas entre os grupos Al e J. Nossa hipótese sobre estes resultados é que o período de $48 \mathrm{~h}$, em que os animais permaneceram em jejum, não foi suficiente para elevar a lactacidemia e/ou alterar a expressão de MCT1 dos adipócitos SC e RP estudados. De qualquer maneira, o resultado referente ao transportador MCT1, mostra que tanto o teste de captação, quanto a gliceroneogênese aumentada nos animais alimentados, em ambos os territórios adiposos não se deveu a alterações no conteúdo nestes transportadores. Talvez, o $\mathrm{K}_{\mathrm{M}}$ deste transportador não se altere e a captação deste substrato seja modulada, simplesmente, pelas diferenças de concentração extra e intracelulares.

Acreditamos que a glicólise no TA esteja intimamente ligada ao aumento da captação do lactato e da gliceroneogênese pelos adipócitos de animais normalmente alimentados. Isto porque, na presença do substrato glicídico, ocorre ativação da via glicolítica e, como consequência, a produção de lactato é estimulada. De acordo com Arraián et al ., (2015), no período pós-prandial, o TA libera aproximadamente 60 a $150 \mu \mathrm{mol} / \mathrm{min}$ de lactato e, além disso, a concentração deste substrato no interior da célula é capaz de estimular a atividade da LDH e consequentemente a conversão do ácido lático a piruvato, permitindo seguir tanto para a geração de ATP, quanto para a síntese de AG e glicerol.

Ao avaliar a expressão da LDH através do Western Blotting, não observamos diferenças estatísticas entre os grupos estudados em ambos os tecidos SC e RP. Não bastante, realizamos a cinética enzimática para avaliar sua atividade. Para a nossa surpresa, no tecido SC a LDH mostrou-se mais ativa no jejum.

Estes resultados colocaram em cheque nossa hipótese anterior, de que no estado alimentado, com a glicólise anaeróbia ativada, haveria como consequência, maior produção de lactato e, com isso, maior atividade da LDH e síntese de glicerol- 
3-P, sendo esta, uma manobra alternativa para a redução do pool intracelular de ácido lático. Para King e Di Girolamo, (1998), o jejum pode aumentar a conversão de glicose a lactato em até $30 \%$, aumentando significativamente sua concentração intracelular. Outro estudo conduzido por Arraián et al., (2015) concluiu que a atividade da LDH não estaria relacionada a diferentes condições metabólicas, mas sim, a diferentes concentrações de lactato intracelular. No entanto, no tecido SC, como já foi mostrado anteriormente, não observamos diferenças significativas na concentração de lactato intracelular e, por este motivo, esta hipótese não explica o motivo do aumento da atividade da enzima LDH.

No tecido visceral RP, onde encontramos maiores níveis de lactato tecidual na situação de jejum, não observamos diferenças significativas em relação à atividade da LDH. Neste teste, observamos atividade menos intensa da enzima (aproximadamente 50\%) quando comparada à do tecido SC. Assim, a baixa atividade da LDH pode ter permitido o aumento de conteúdo tecidual de lactato no coxim adiposo. Por outro lado, adipócitos maiores, como os do coxim RP, parecem ser mais afastados de vasos sanguíneos, o que reduz sua oxigenação. Neste sentido, a atividade glicolítica anaeróbia aumentaria significavamente produção local deste substrato. 


\section{Conclusão}

Concluímos que jejum prolongado promove redução da lipogênese e gliceroneogênese a partir de ácido lático em relação ao estado alimentado, embora não tenhamos observado diferenças estatísticas na expressão de proteínas envolvidas na gliceroneogênese. Com relação às diferenças da atividade da enzima LDH, parece que alterações metabólicas e/ou morfológicas entre os tecidos SC e RP foram determinantes nos resultados obtidos. Além disso, a glicose e a insulina mostraram-se importantes potencializadores da lipogênese a partir do lactato, desde sua captação até sua incorporação em glicerol-3-P em adipócitos isolados tanto de animais alimentados quanto submetidos ao jejum por $48 \mathrm{~h}$.

Estes dados trazem informações importantes sobre aspectos do metabolismo lipogênico e sobre a gliceroneogênese no jejum e no estado alimentado que ainda não haviam sido exploradas, como a atuação das gorduras visceral e subcutânea as particularidades destes coxins adiposos no metabolismo de lípides, e abrem uma nova área de exploração da contribuição sobre o papel do tecido adiposo no metabolismo energético em relação a condição alimentar do animal. 


\section{REFERÊNCIAS*}

Ameer F, Scandiuzzi L, Hasnain S, Kalbacher H, Zaidi N. De novo lipogenesis in health and disease. Metabolism. $2014 \mathrm{Jul} ; 63(7): 895-902$.

Ali AH, Koutsari C, Mundi M, Stegall MD, Heimbach JK, Taler SJ, Neygren J, Thoresll A, Bogachus LD, Turcotte LP, Bernlohr D, Jensen M. Free Fatty Acid Storage in Human Visceral and Subcutaneous Adipose Tissue Role of Adipocyte Proteins. Diabetes. 2011;60(9):2300-7.

Arriarán S, Agnelli S, Sabater D, Remesar X, Fernández-López JA, Alemany M. Evidences of basal lactate production in the main white adipose tissue sites of rats. PLoS One. 2015, 10 (3):1-19.

Akran M. J Med Food. A focused review of the role of ketone bodies in health and disease. 2013;16(11):965-7.

Beale EG; Hammer RE; Antonie B; Forest C. Glyceroneogenesis comes of age. FASEB J. 2002; (16): 1695-6.

Benetti M, Santos RT, Carvalho T. Cinética de lactato em diferentes intensidades de exercícios e concentrações de oxigênio. Rev Bras Med Esporte. 2000; (6): 50-56.

Bergmeyer HU; Bernt E; Schmidt F; Stork H. In: BERGMEYER, H.U. (Ed). Methods of enzymatic analysis. Orlando academic Press. 1974 p. 1196-1201.

Botion LM; Brito MN; Brito NA; Brito SRC; Kettelhut I. C; Migliorini RH. Glucose contribution to in vivo synthesis to glyceride - glycerol and fatty acids in rats adapted to a high-protein, carbohydrate free diet. Metabolism. 1998 (47): 1217- 21.

Bouchard C; Després J-P; Mauriége P. Genetic and Nongenetic Determinants of Regional Fat Distribution. Endocr Rev.1993 Feb;14 (1):72-93.

Brito MN; Brito NA; Garófalo MA; Kettelhut IC; Migliorini RH. Synpathetic activity in brown adipose tissue from rats adapted to high protein, carbohydrate free diet. J Auton Nerv Syst. 1998; 69 (1): 1-5.

Britto SRC, Moura MAF, Kawashita NH, Brito MN, Kettelhut IC, Migliorini RH. Glucose uptake and glycolytic flux in adipose tissue from rats adapted to a highprotein, carbohydrate-free diet.Metabolism . 2001; (50)10:1208-12.

*De acordo com:

International Committee of Medical Journal Editors. [Internet].Uniform requeriments for manuscripts submitted to biomedical journals. [2011 Jul 15]. Avaliable from: http://www.nlm.nih.gov/bsd/uniform_requeirements.html. 
Brooks GA. Cell-cell and intracelular lactate shuttles. J Phisyol. 2009; 587(23):5591600

Cadoudal T, Leroyer S, Reis AF, Tordjman J, Durant S, Fouque F, Collinet M, Quette J, Chauvet G, Beale E, Velho G, Antoine B, Benelli C, Forest C. Proposed involvement of adipocyte glyceroneogenesis and phosphoenolpyruvate carboxykinase in the metabolic syndrome.Biochimie. 2005 Jan;87(1):27-32

Cadoudal T, Blouin JM, Collinet M, Fouque F, Tan GD, Loizon E, Beale EG, Frayn KN, Karpe $\quad F$, Vidal H, Benelli $\quad$ C, Forest Acute and selective regulation of glyceroneogenesis and cytosolic phosphoenolpyruv ate carboxykinase inadipose tissue by thiazolidinediones in type 2 diabetes.

Diabetologia. 2007; 50(3):666-75.

Castro NC. O volume celular do adipócito contribui para a heterogeneidade funcional do tecido adiposo branco. [Dissertação (Mestrado em Fisiologia Humana)]. São Paulo: instrituto de Ciencias Biomédicas, Universidade de São Paulo; 2010.

Ceddia RB. Tehe role of AMP-activated protein kinase in regulating white adipose tissue metabolism. Mol Cell Endocrinol. 2013; (366):194-203.

Chaves V; Frasson D; Martins-Santos MES; Boschini RP; Garófalo MAR; Festuccia WTL ; Kettelhut I. C; Migliorini RH. Glyceroneogenesis Is Reduced and Glucose Uptake Is Increased in Adipose Tissue from Cafeteria Diet-Fed Rats Independently of Tissue Sympathetic Innervation. J Nutr. 2006; (136): 2475-80.

Cinti S. The adipose organ at a glance. Dis Model Mech. 2012; (5): 588-94

Cinti S. The adipose organ. Prostag Leukotr Ess. 2005; (73): 9-15.

Czech MP, Tencerova M, Pedersen DJ, Aouadi M. Insulin Signalling Mechanisms for Triacylglycerol Storage. Diabetologia. 2013; (56): 949-64.

Di Girolamo M, Fine JB, Tagra K, Rossamith R. Qualitative regional diferences in adipose tissue growth and cellularity in male wistar rats fed ad libitum. Am Physiol Soc. 1998; (274):1460-67.

Donato JJ, Pedrosa RG, Tirapegui J. Braz J Pharm Sci. 2004; (40): 273-87.

Eichmann TO, Kumari M, Haas JT, Farese RV, Zimmermann RJ, Lass A, Zechner R. Studies on the Substrate and Stereo/Regioselectivity of Adipose Triglyceride Lipase, Hormone-sensitive Lipase, and Diacylglycerol-O-acyltransferases. J Biol Chem. 2012;(287):41446-57.

Ellmerer M, Schaupp L, Sendlhofer G, Wutte A, Brunner GA, Trajanoski Z, Skrabal F, Wach P, Pieber TR. Lactate metabolism of subcutaneous adipose tissue studied by open flow microperfusion. J Clin Endocrinol Metab. 1998;83 (12):4394-401.

Kovacs EMR, Westerp-Plantenga, MS. Effects os (-)-hydrocycitrate on net fat synthesis as de novo lipogenesis. Phisiol Behav. 2006; (88):371-81 
Fonseca-Alaniz $\mathrm{MH}$, Takada J, Alonso-Vale MI, Lima FB. The adipose tissue as a regulatory center of the metabolism. Arq Bras Endocrinol Metabol. 2006; 50(2):21629.

Forest C, Tordjman J, Glorian M, Duplus E, Chauvet G, Quette J, Beale EG, Antoine B. Fatty acid recycling in adipocytes: a role for glyceroneogenesis and phosphoenolpyruvate carboxykinase. Biochem Soc Trans. 2003;31(6):1125-9.

Franckhauser S; Munoz S; Pujol A; Casellas A; Riu E; Otaegui P; Su B; Bosch F. Increased Fatty Acid Re-esterification by PEPCK Overexpression in Adipose Tissue Leads to Obesity Without Insulin Resistance. Diabetes. 2002; (51): 624-30.

Frasson D; Boschini RP; Chaves V. E; Martins dos Santos ME; Gomes SP; Valentim RR; Garófalo MAR; Navegantes LCC; Migliorini RH; Kettelhut IC. The sympathetic nervous system regulates the three glycerol-3P generation pathways in white adipose tissue of fasted, diabetic and high-protein diet-fed rats. Metabolism. 2012; (61): 1473- 85.

Foufelle F, Girard J, Ferré P.Regulation of lipogenic enzyme expression by glucose in liver and adipose tissue: a review of the potential cellular and molecular mechanisms. Adv Enzyme Regul. 1996 (36):199-226.

Fruhbeck G, Gomez-Ambrosi J, Muruzabal FJ, Burrell MA. The adipocyte: a model for integration of endocrine and metabolic signaling in energy metabolism regulation. Am J Physiol Endocrinol Metab. 2001; (280): 827-47.

Garaulet M, Hernandez Morante JJ, Lujan J, Tebar FJ, Zamora F. Relation ship between fat cell size and number and fatty acid composition in adipose tissue from differente fat depots in overweight/ obese humans. Int J Obesity. 2006 (30):899-905

Giorgino F, Laviola L, Eriksson JW. Regional differences of insulin action in adipose tissue: insights from in vivo and in vitro studies. Acta Physiol Scand. 2005; 183(1):1330.

Hajduch E, Heyes RR, Waltt PW, Hundal HS. Lactate transport in rat adipocytes: identification of monocarboxylate transporter 1 (MCT1) and its modulation during streptozotocin-induced diabetes. FEBS Lett. 2000;479 (3):89-92.

Halestrap A. P. The Monocarboxylate Transporter Family-Structure and Functional Characterization.IUBMB Life. 2012; 64(1): 1-9.

Hanson RW; Reshef L. Glyceroneogenesis revisited. Biochimie. 2003;(85):1199_ 1205.

Heber D.An integrative view of obesity. Am J Clin Nutr. 2010; (91): 280-3.

Heredia F. P; Wood I. S; Trayhurn P. Hypoxia stimulates lactate release and modulates monocarboxylate transporter (MCT1, MCT2, and MCT4) expression in human adipocytes. Eur J Physiol. 2010; (459):509-518. 
Herman MA, Peroni OD, Villoria J, Schön MR, Abumrad NA, Blüher M, Klein S, and Kahn BB. A novel ChREBP isoform in adipose tissue regulates systemic glucose metabolism. Nature. 2012;484(7394):333-8.

Hermsdorff HHM; Monteiro JBR. Visceral, subcutaneous or intramuscular fat: where is the problem?. Arq Bras Endocrinol Metab. 2004; 48(6): 803-11.

Huang S, Czech MP. The Glut 4 transporter. Cell Metab. 2007; (5): 237-52.

Im SS, Kwon BK, Kang SY, Kim TH, Kim H, Hur MW, Kim KS, Ahn YH. Regulation of GLUT4 gene expression by SREBP-1c in adipocytes. Biochem. J. 2006;(399): 131-39.

Jensen MD, Ekberg K, Landau BR. Lipid metabolism during fastin. Am. J Physiol Endocrinol Metab. 2001;281(4):789-93

Jensen MD. Lipolysis: Contribution from regional fat. Annu Rev Nutr.1997; (17):12739.

Jernås M, Palming J, Sjöholm K, Jennische E, Svensson PA, Gabrielsson BG, Levin M, Sjögren A, Rudemo M, Lystig TC, Carlsson B, Carlsson LM, Lönn M. Separation of human adipocytes by size: hypertrophic fat cells display distinct gene expression.FASEB J. 2006 ;20(9):1540-2.

Jomain M, Hanson RW. Dietary protein and the control of fatty acid synthesis in rat adipose tissue. J Lipid Res.1969;(10):674-80.

Kalhan SC; Mahajan S; Burkett E; Reshef L; Hanson RW. Glyceroneogenesis and the source of glycerol for hepatic triacylglycerol synthesis in humans. J. Biol Chem. 2001; (276): 12928-31.

Karastrgiou K, Mohamed -Ali V. The autocrine and Paracrine roles of Adipokines. Mol Cell Endocrinol. 2010;(318):69-78

Kim JB, Spiegelman BM. ADD1/SREBP1 promotes adipocyte differentiation and gene expression linked to fatty acid metabolism. Genes Dev. 1996;10 (9):1096-107.

King JL, DiGirolamo M. Lactate production from glucose and response to insulin in perifused adipocytes from mesenteric and epididymal regions of lean and obese rats. Obes Res. 1998; 6(1):69-75.

Korbonits M, Blaine D, Elia M, Powell-Tuck J. Metabolic and hormonal changes during the refeeding period of prolonged fasting. Eur J Endocrinol. 2007; (157):15766.

Lafontan M, Langin D. Lipolysis and lipid mobilization in human adipose tissue. Prog Lipid Res. 2009; 48(5): 275-97.

Lawson E. A; Eddy K. T; Donoho D; Misra M; Miller K. K; Meenaghan E; Lydecker J; Herzog D; Klibanski A. Appetite-regulating hormones cortisol and peptide YY are associated with disordered eating psychopathology, independent of body mass index. Eur J Endocrinol. 2011;(164): 253-61. 
Long YC \& Zierath JR. AMP- active protein Kinase signaling in metabolic regulation.J Clin Invest. 2006;16(7):1776-83.

Lovejoy J, Newby FD, Gebhart FD, Di Girolamo M. Insulin Resistance in Obesity is associated with elevated basal lactate levels and diminished lactate appearance following intravenous lactate and insulin. Metabolism.1992; 41(1): 22-7

Meyhunas O, Reshef L, Ballard J, Hanson RW. The effect of Insulin and glucorticoids on the synthesis and degradation of Phosphoenolpyruvate Carboxykinase (GTP) in rat adipose tissue cultured in vitro. Biochem.1976; (158): 9-16.

Muñoz S, Franckhauser S, Elias I, Ferré T, Hidalgo A, Monteyes AM, Molas M, Cerdá S, Pujol A, Ruberte J, Bosch F. Chronically increased glucose uptake by adipose tissue leads to lactate production and improved insulin sensitivity rather tha obesity in the mouse. Diabetologia .2010; (53): 2417-30.

Newby FD, Sykes MN, DiGirolamo M. Regional differences in adipocyte lactate production from glucose. Am J Physiol. 1988 (255):716-22

Nye CK; Hanson RW; Kalhan S. C.Glyceroneogenesis Is the Dominant Pathway for Triglyceride Glycerol Synthesis in Vivo in the Rat. J Biol Chem. 2008;283(41): 276574.

Nye C, Kim J, Kalhan SC, Hanson RW. Reassessing triglyceride synthesis in adipose tissue. Trends Endocrinol Metab. 2008;19(10):356-61.

Olswang Y; Cohen H; Papo O; Cassuto H; Croniger CM; Tilghman PHM, Hanson R. W Reshef $L$. A mutation in the peroxisome proliferator-activatedreceptor -binding site in the gene for the cytosolic form of phosphoenolpyruvatecarboxykinase reduces adipose tissue size and fat content in mice. PNAS. 2002; 99(2): 625-30.

Palou M, Priego T, Sánchez J, Villegas E, Rodiguez AM, Palou A, et al. Sequencial changes in the expression of genes involved in lipid metabolism in adipose tissue and liver in response to fasting. Pflugers Arch. 2008; (456): 25-36.

Palou M, Sánchez J, Priego T, Rodríguez A M, Picó C, Palou A. Regional Differences in the expression of genes involved in lipid metabolim in adipose tissue in response to short-and medium-term fasting and refeeding. J Nutr Biochem. 2010; (21):23-33.

Robin JP, Decrock F, Herzberg G, Mioskowski E; Le Maho Y; Bach A; Groscolas R. Restoration of Body Energy Reserves during Refeeding in Rats Is Dependent on Both the Intensity of Energy Restriction and the Metabolic Status at the Onset of Starvation. J. Nutr. 2008; (138): 861-66.

Rodbell, M. Metabolism of isolated fat cells. J Biol Chem. 1964; 239(2):375-80.

Romero MM, Sabater D, Fernández-Lpoes JA, Remesar X, Alemany M. Glycerol Production from Glucose and Fructose by 3T3-L1 Cells: A Mechanism of Adipocyte Defense from Excess Substrate. PLoS ONE. 2015; 10(10):1-18 
Sánchez J, Palou A., Picó C. Response to Carbohydrate and Fat Refeeding in the Expression of Genes Involved in Nutrient Partitioning and Metabolism: Striking Effects on Fibroblast Growth Factor-21 Induction. Endocrinology. 2009;(150):534150.

Reidy SP, Webwe JM. Accelered substrate cycling: a new energy-wasting role for leptin in vivo. Am J Physiol Endocrinol Metab. 2002;(282): E312-17

Sucajtys-Szulc E, Goyke E, Korczynska J, Stelmanska E, Rutkowski B, SwierczynskiJ. Reefeding after prolonged food restriction differencially affects hypothalamic and adipose tissue leptin gene expression. Neuropeptides. 2009;(73) :321-25.

Trepanowski JF; Bloomer RJ .The Impact of religious fasting on human health. Nutr J. 2010; (57):1- 9.

van den Borst B, Schols AMWJ, Theije C, Boots AW, Köhler SE, Goossens $\mathrm{GH}$, Gosker HR. Characterization of the inflammatory and metabolic profile of adipose tissue in a mouse model of chronic hypoxia.J Appl Physiol. 2013;(114):1628.

Vanz JS, Deboni F, Azevedo MJ, Gross JL, Zelmanovitz T. Ácidos Graxos como marcadores biológicos da ingestão de gorduras. Rev Nutr Campinas. 2006;19 (4):489-500.

Vásquez-Vela MEF, Torres N, Tovar AR. White Adipode Tissue as Endocrine Organ and Its Role in Obesity. Arch of Medical Research. 2008: (39):715-28.

Wan Z, Matravadia S, Holloway GP, Wright DC. FAT/CD36 regulates PEPCK expression in adipose tissue. Am J Physiol Cell Physiol. 2013; 304(5):C478-84

Weber JM, Reidy SP. Etending food deprivation reverses the short-term lipolytic response to fasting: role of triacylglycerol/fatty acid cycle. J Exp Biol. 2012; (215):1484-90.

Wu Q, Ortegon AM, Tsang B, Doege H, Feingold KR, Stahl A. FATP1 is an insulin sensitive fatty acid transporter involved in diet-induced obesity. Mol Cell. 2006;(26):3455-67

Ying- Lee R, Zhang QH, Qiao J, Zhao SX, Shao L, Xiao HS, Chen JL, Chen MD, Song HD. Effect of short-term and long-term fasting on transcriptional regulation of metabolic genes in rat tissues. Bioch Bioph Res Co. 2006;(344): 562-70

Zammit VA, Newsholme EA. The maximum activities of hexokinase, phosphorylase, phosphofructokinase, glycerol phosphate dehydrogenases, lactate dehydrogenase, octopine dehydrogenase, phosphoenolpyruvate carboxykinase, nucleoside diphosphatekinase, glutamate-oxaloacetate transaminase and arginine kinase in relation to carbohydrate utilization in muscles from marine invertebrates. Biochem J. 1976;(160):447-62. 
Zanqueta MM, Nascimento MED, Moria RCT, Schaanb BD, Youngc ME, Machado UF. Participation of b-adrenergic activity in modulation of GLUT4 expression during fasting and refeeding in rats. Metab Clin Exp. 2006;(55): 1538- 45. 